\title{
MAHTOUTABAD III (PROVINCE OF KERMAN, IRAN): AN “URUK-RELATED” MATERIAL ASSEMBLAGE IN EASTERN IRAN
}

\author{
By F. Desset*, M. Vidale** and N. Alidadi Soleimani*** \\ * UMR 7041/ArScAn \\ ** Dept. of Cultural Heritage, University of Padua \\ *** ICCHTO, Kerman
}

\begin{abstract}
During recent excavations in the third-millennium BC plundered graveyard of Mahtoutabad, next to Konar Sandal (Kerman, Iran), the authors excavated layers with Uruk-related ceramics. The types include bevel-rim bowls, flowerpots, low-sided trays, nose-lugged jars and other types previously encountered at several other contemporary sites in highland Iran. This new material is presented here with some preliminary comments on the general picture of the Uruk-related sites and pottery assemblages across the Iranian plateau of the midand late fourth millennium BC. We suggest that the related elements of the material culture of these contexts should be considered as open single questions, rather than as part of a monolithic cultural pattern awash with demanding historical or even ethnic implications.

Keywords

Mahtoutabad site; Konar Sandal; Halil Rud culture; Uruk phenomenon on the Iranian plateau; ancient ceramic technology
\end{abstract}

\section{INTRODUCTION}

The ceramic assemblage we present in this paper comes from a single trench dug in a small, peripheral site of the Konar Sandal site complex, which lies near the present town of Jiroft in the Kerman province of Iran, and is best known for the recent ruinous pilferage of its third-millennium $\mathrm{BC}$ graveyards. Although the whereabouts and archaeological contexts of the original occupation from which this pottery originated are still unknown, the assemblage represents, so far, the easternmost evidence of the Uruk phenomenon across the Iranian plateau. The deposits that were excavated are clearly secondary but they are coherent from a chronological and cultural viewpoint, and will help us better to evaluate the assemblages of Tal-i Iblis, where stratigraphy was not fully controlled, and those of Tepe Yahya, with its much-discussed associations. We believe that the holistic evaluation of these three sites (Tal-i Iblis IV-VI; Tepe Yahya IVC; Mahtoutabad III) will eventually be useful to build up a new frame of reference for the Kerman region in the mid- to late fourth millennium BC.

Iran LI 2013, 17-54 $\quad$ C 2013 The British Institute of Persian Studies
The site of Mahtoutabad (282 $\left.27^{\prime} 20^{\prime \prime} \mathrm{N} ; 57^{\circ} 47^{\prime} 26^{\prime \prime} \mathrm{E}\right)$ lies about $1.4 \mathrm{~km}$ south-east of the Konar Sandal North Tepe and $1.3 \mathrm{~km}$ north-east of the Konar Sandal South early urban complex (Figs. 1 and 2). ${ }^{1}$ The site, plundered with other local graveyards in 2001 (Fig. 3), was investigated as part of a rescue operation carried out between 2006 and 2009. The first campaign took place in January-February 2006, under the direction of Y. Madzjidzadeh. The graveyard (period Mahtoutabad IV) had been used in the second half of the third millennium BC on top and beside a natural bank at the edge of the bed of the Halil River (Fig. 4). At the time the bank must have risen 1-2 $\mathrm{m}$ higher than the surrounding plain, and thus protected the graves from the most immediate risks of flooding, until the area was sealed by thick silty alluvial layers, presumably in the historical period. Following a major flood in 2001, the current bed of the Halil finally cut through the burial area along its right bank on the west, ${ }^{2}$ exposing the graves and their rich furnishings. A small number of other graves were plundered on the eastern side of the

Madjidzadeh and Pittman 2008; Vidale and Desset 2013. Fouache et al. 2005: 121. 


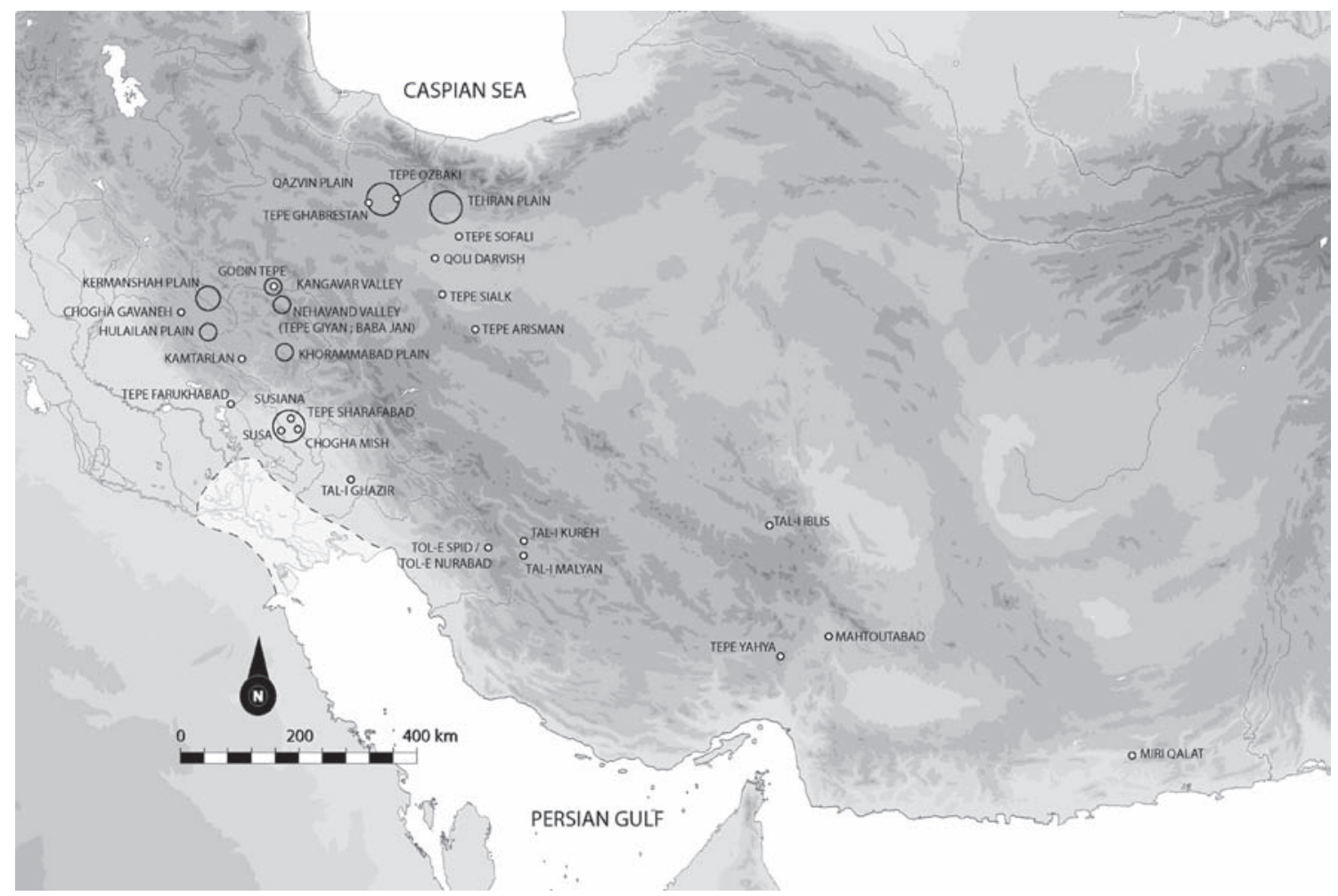

Fig. 1. Sites and areas east of Mesopotamia where so-called "Uruk-related" ceramics were found (see also Butterlin 2003: pl. 1; Potts D.T. 2009: 2). (Image F. Desset.)

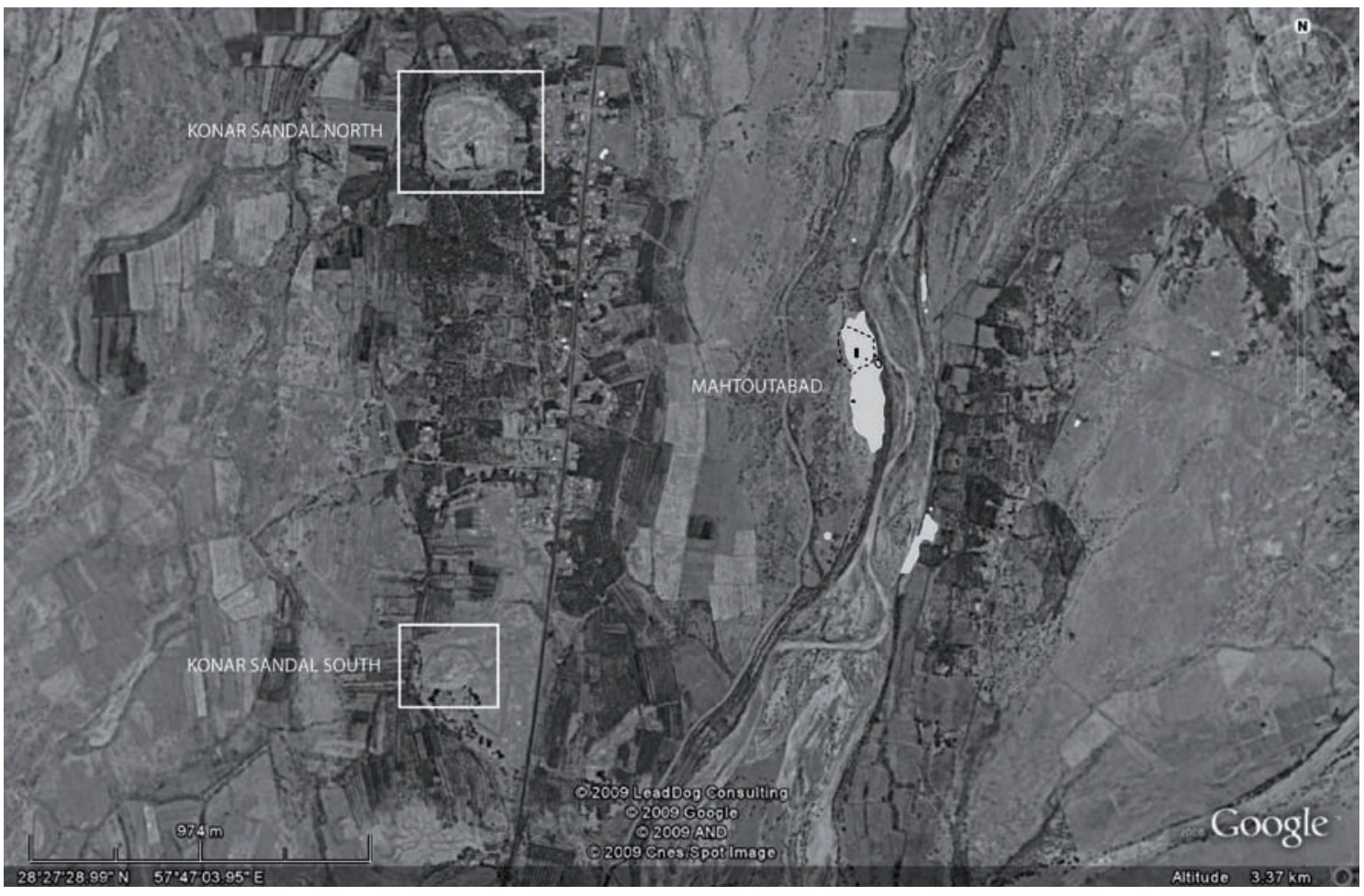

Fig. 2. The archaeological area of Konar Sandal, with the location of the Mahtoutabad looted site. (Image F. Desset.) 


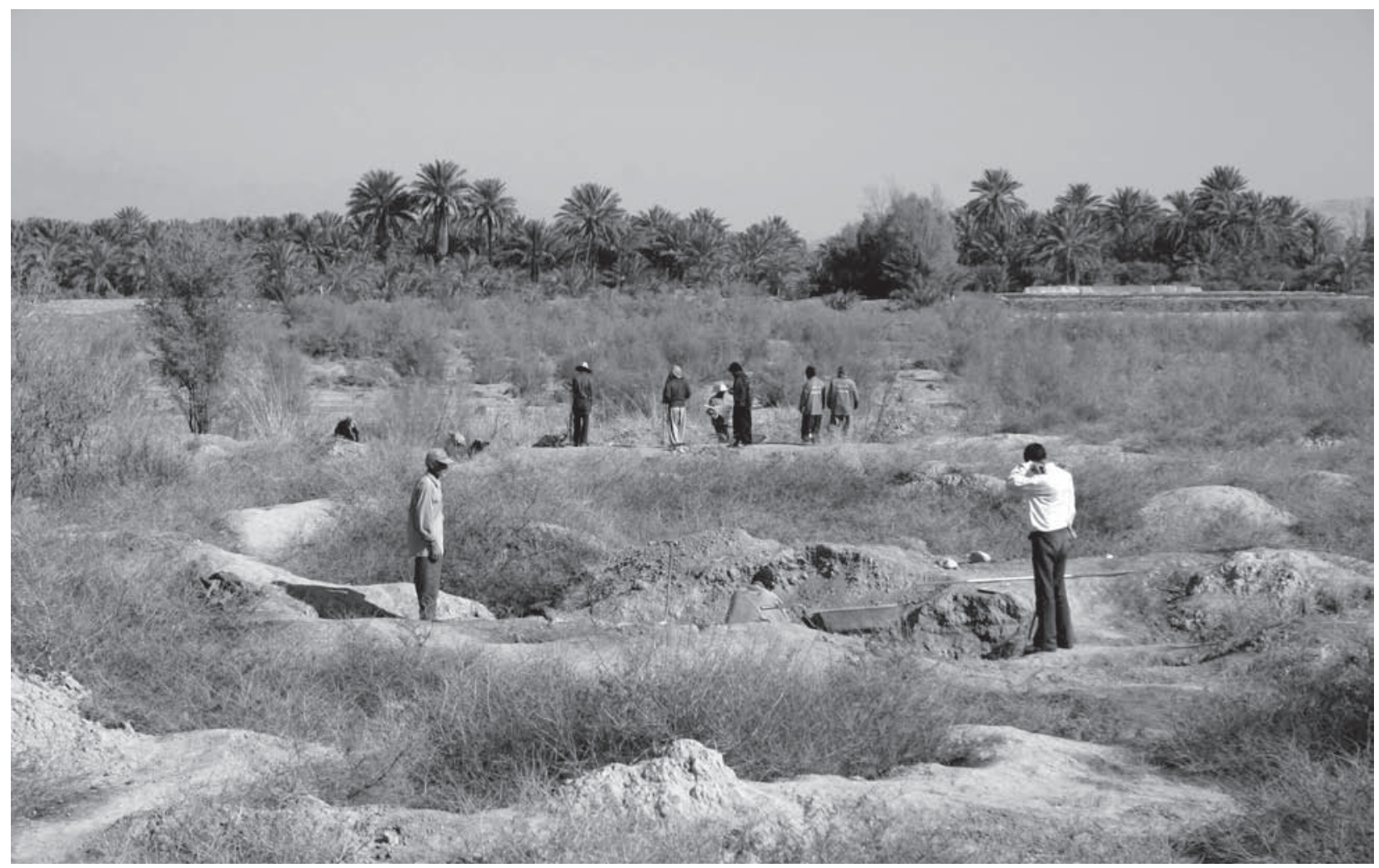

Fig. 3. Mahtoutabad: general view of the area investigated with Trench V. In the background, the bed of the Halil Rud. (Image M. Vidale.)

present bank. Without this flood and the destruction led by the plunderers, the underlying late prehistoric settlements would never have been found, because no artificial elevation or scatter of artefacts was visible on the currently cultivated surfaces.

Our main operation, Trench I, enabled us to recover large amounts of artefacts discarded by the illegal diggers that date to the graves of the second half of the third millennium BC (Mahtoutabad IV). While surveying the eastern fringe of the main burial area along the current western bank of the Halil, where illegal digs had been systematic and intensive, we found clustered fragments of bevel-rim bowls (hereafter BRBs) scattered on the surface of the excavation dumps and in the fillings of the robbers' trenches. Other sherds of the same type were still embedded in layers of ceramics and other cultural materials exposed by the vertical pits' sections. We excavated this site under the label of Trench V. The ceramics were comparable to various mid- to late fourth-millennium $\mathrm{BC}$ assemblages previously known in other sites of the Iranian plateau, and the relative phase of occupation was named Mahtoutabad III. Trench I also revealed, below the level of the third-millennium BC graves, a thick deposit of Iblis IV-related ceramics, suggesting that the area had been settled in the early to mid-fourth millennium BC (Mahtoutabad II; Desset, Vidale and Alidadi Soleimani, ongoing research).

The earliest local settlement (Mahtoutabad I) was reached at a depth of about $4 \mathrm{~m}$ below the surface in Trench I. Here, we unearthed half of a large oval hut with post holes on the virgin soil, associated to a distinctive polychrome pottery. Four calibrated radiocarbon-AMS dates place this period between c. 4200 and 3700 BC. ${ }^{3}$ Thus, although deeply disturbed, the site of Mahtoutabad revealed an important sequence of occupation stretching for much of the fourth millennium BC, which allows a first glance at the material assemblage of formative stages of the local Halil Rud cultural assemblage.

$3 \quad$ Vidale and Desset 2013. 


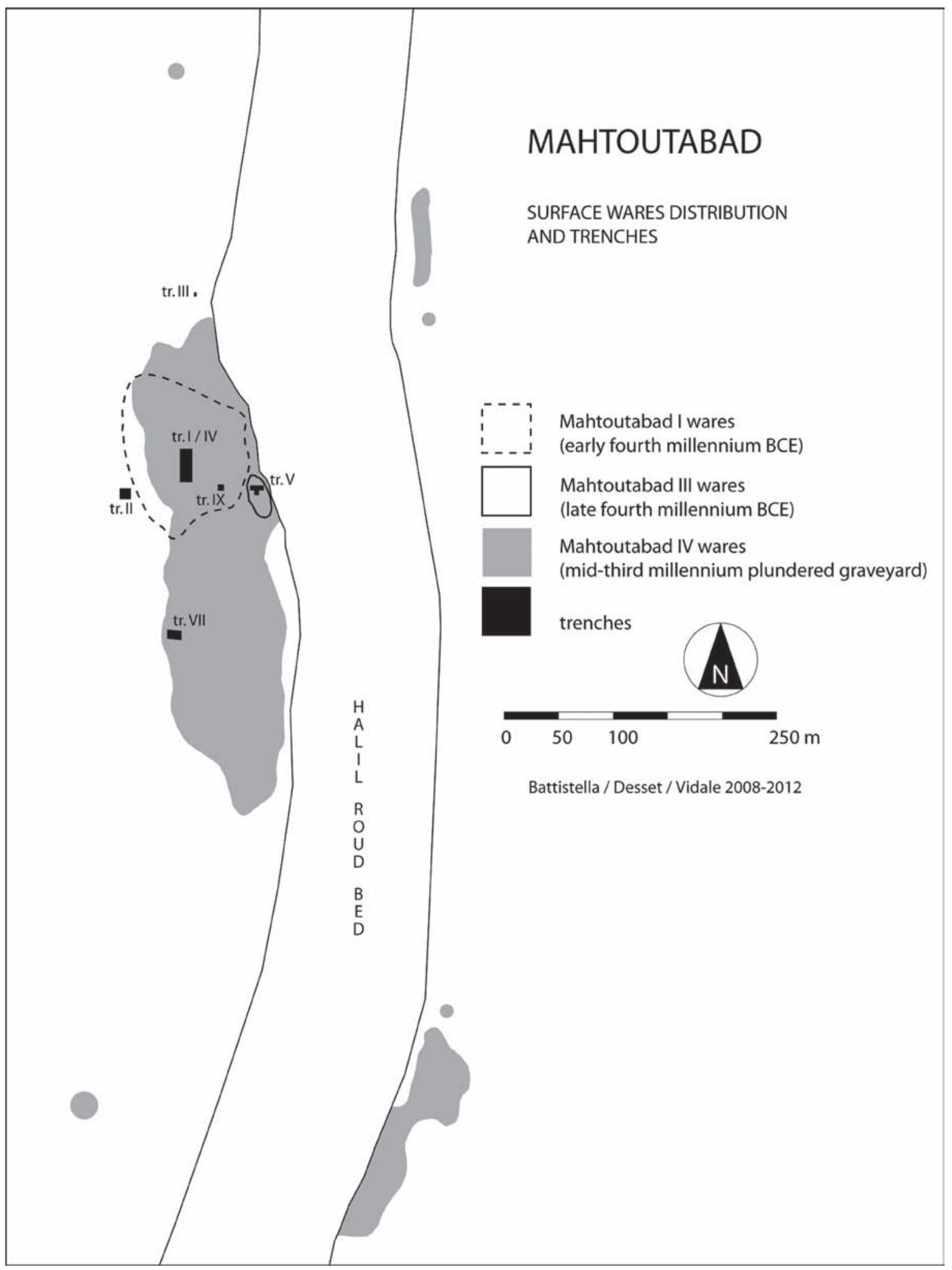

Fig. 4. Map of the Mahtoutabad site, showing the location of the excavated trenches, the original extent of the graveyard (Mahtoutabad IV) and the probable limits of the Mahtoutabad I and Mahtoutabad III local deposits.

(Image Battistella, F. Desset and M. Vidale.) 


\section{STRATIGRAPHY OF TRENCH V AND SITE DEPOSITIONAL PROCESSES}

The Uruk-related materials related to period Mahtoutabad III, which were found in Trench V, came from horizontal or slightly sloping layers of clayey silt beside the Halil Rud. No architectural feature was recognised. Trench V (Figs. 4 and 5) was originally planned as a strip measuring $9.5 \times 4.5 \mathrm{~m}$, the longer side oriented west-east (i.e. orthogonal to the nearby riverbank). Its main purpose was to excavate whatever was left of the Mahtoutabad III layers. In fact, we uncovered patches of an extensive surface almost completely destroyed by the robbers who, having found dozens of complete vessels, were hoping to locate other graves. The undisturbed deposits were small residual strips, from $c .0 .50-1 \mathrm{~m}$ wide, surviving among the looting pits (Figs. 6, 7 and 8). The diggers had, typically, also excavated below the archaeological layers, with horizontal tunnels connecting one pit to another. Thus, defining the formation processes of the Mahtoutabad III layers at the site was a painstaking and rather frustrating process, but in spite of the damage, it was possible to find secure stratigraphic contexts.

In January-February 2009, our last season at Mahtoutabad, Trench V was enlarged laterally and deepened under the co-direction of M. Vidale and N. Alidadi Soleimani, mainly to collect a larger sample of the ceramics of this occupation. On the western side of the exposed area we found several complete vessels, mainly BRBs, and many fragments of fired plaster and fired jar sealing fragments, all in a primary context of deposition. To the east (i.e. towards the present riverbed) the cultural materials had been transported, scattered and finally deposited by natural processes (layer TV-9). The coherence of the ceramic assemblage, free from earlier or later materials, suggests that the Trench $\mathrm{V}$ deposits belong to a single phase of occupation, perhaps an open area at the edge of a nearby fourthmillennium $\mathrm{BC}$ settlement.

The stratigraphy of Trench V can be analytically described with reference to the eastern side of the northern section (Figs. 5 and 9). The layer descriptions are as follows:

- Layer TV-1: debris from the 2001 looting pits in a heap collapsing eastwards. Loose silty sand with clay lumps and silty clay sods of variable colours.

- Layer TV-2: a heap of pure loose greyish-brown sand $(2.5 \mathrm{Y} 5 / 2)$, in secondary context of deposi- tion, excavated from the thick deposits of sand of the 2001 flood and dumped beside the pits.

- Layer TV-3: slightly sandy silt abundantly mottled with whitish (carbonatic) inclusions. It has a prismatic structure and strong vertical cracks made by roots and enhanced by the strong desiccation of the local bank (brown to pale brown, 10 YR 6.3-10 YR 5.3).

- Layer TV-4: alluvial sandy silt. Inhomogeneous, made of dark (dark greyish brown, 10 YR 4.2) and lighter (pale brown, 10 YR 6.3) matrix components. It included pebbles, fired clay particles and a small number of potsherds (types characteristic of Mahtoutabad II and III).

- Layer TV-5: an inhomogeneous horizon of slightly clayey silt, with a greater amount of isolated calcareous inclusions (up to $1 \mathrm{~cm}$ in diameter, white, 10 YR 8.2). The matrix is distinguished by a darker colour (dark greyish brown, 10 YR 4.2).

- Layer TV-6: slightly sandy silt (pale brown, $10 \mathrm{YR}$ 6.3) free from any anthropic inclusion.

- Layers TV-7 and TV-8: two brown (10 YR 5/3) layers of massive alluvial silty clay, about $12-15$ $\mathrm{cm}$ thick. These two layers are hard, compact and pure, and crack with vertical fissures. Between layers 6 and 7,7 and 8 and 8 and 9, there are thin horizontal layers of an extremely fine clay or loesslike deposit, the colour of which (very light brown, 10 YR 7/3) sharply contrasts with layers 7, 8 and 9. TV-7 and 8 are probably decreasing energy flow deposits left on the riverbank by flood events, alternating with drought episodes corresponding to exposed sedimentary surfaces marked by thin aeolian deposits.

- TV-9: this thick alluvial layer of sandy silt (dark greyish brown, 10 YR 4.2) contained sizable quantities of large Mahtoutabad III (c. mid-late fourthmillennium $\mathrm{BC}$ ) potsherds, rocks cracked by fire, a few animal bones and evidence of lithic industry and other cultural materials deposited across an extensive open-air surface. While the top of this alluvial layer hosts sherds in sub-horizontal settings, it also included larger fragments or complete vessels that were more chaotically arranged. This paper deals mainly with the material found in this layer.

- TV-10: another thick layer of pale brown (10 YR $6 / 3$ ) clayey silt, apparently free from any anthropic inclusions. Its lower stratigraphic limit was not exposed. 


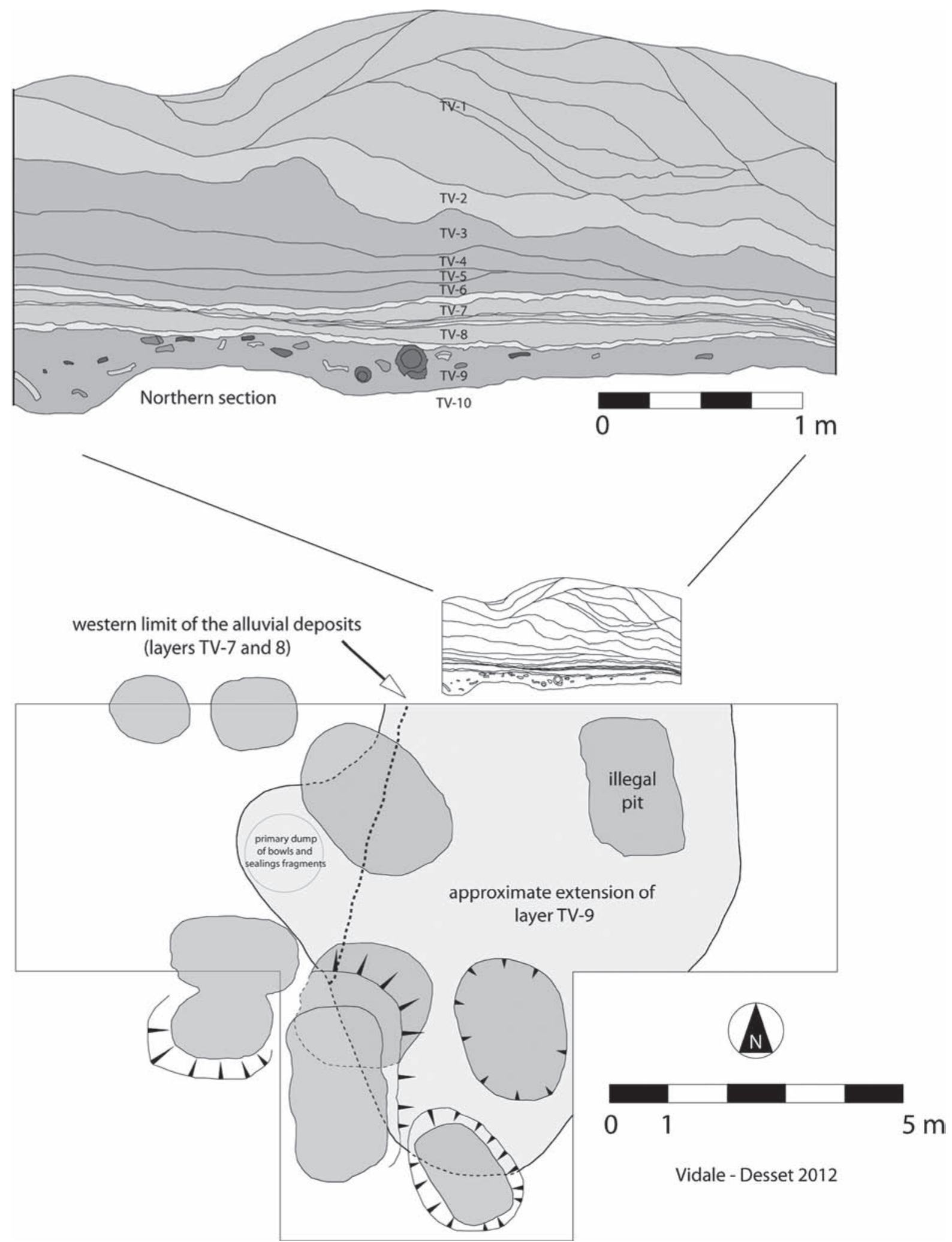

Fig. 5. Mahtoutabad: (below) map of trench V (2007-2009); (above) northern stratigraphic section. (Image M. Vidale and F. Desset.) 


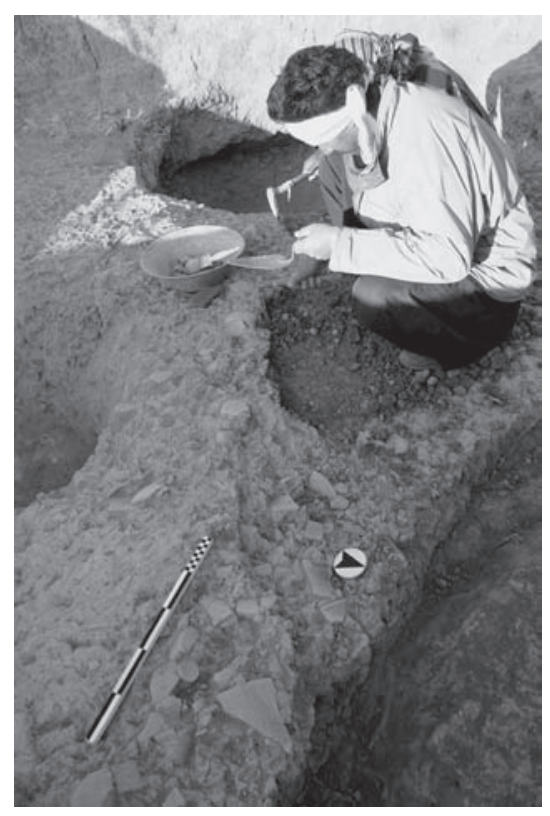

Fig. 6. Mahtoutabad: a phase of the excavation, showing the excavated patches of undisturbed stratigraphy among the pits and tunnels dug by looters. (Image M.Vidale.)

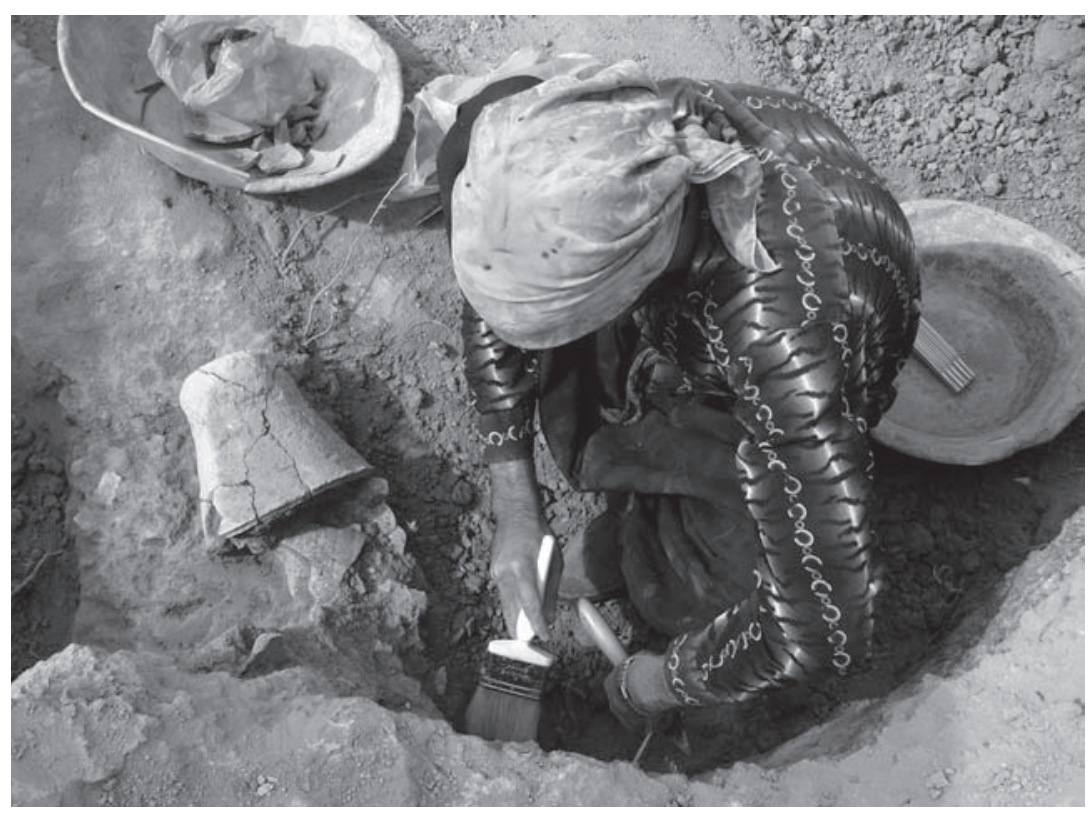

Fig. 7. Mahtoutabad: excavating a complete bevel-rim bowl. (Image M. Vidale.)

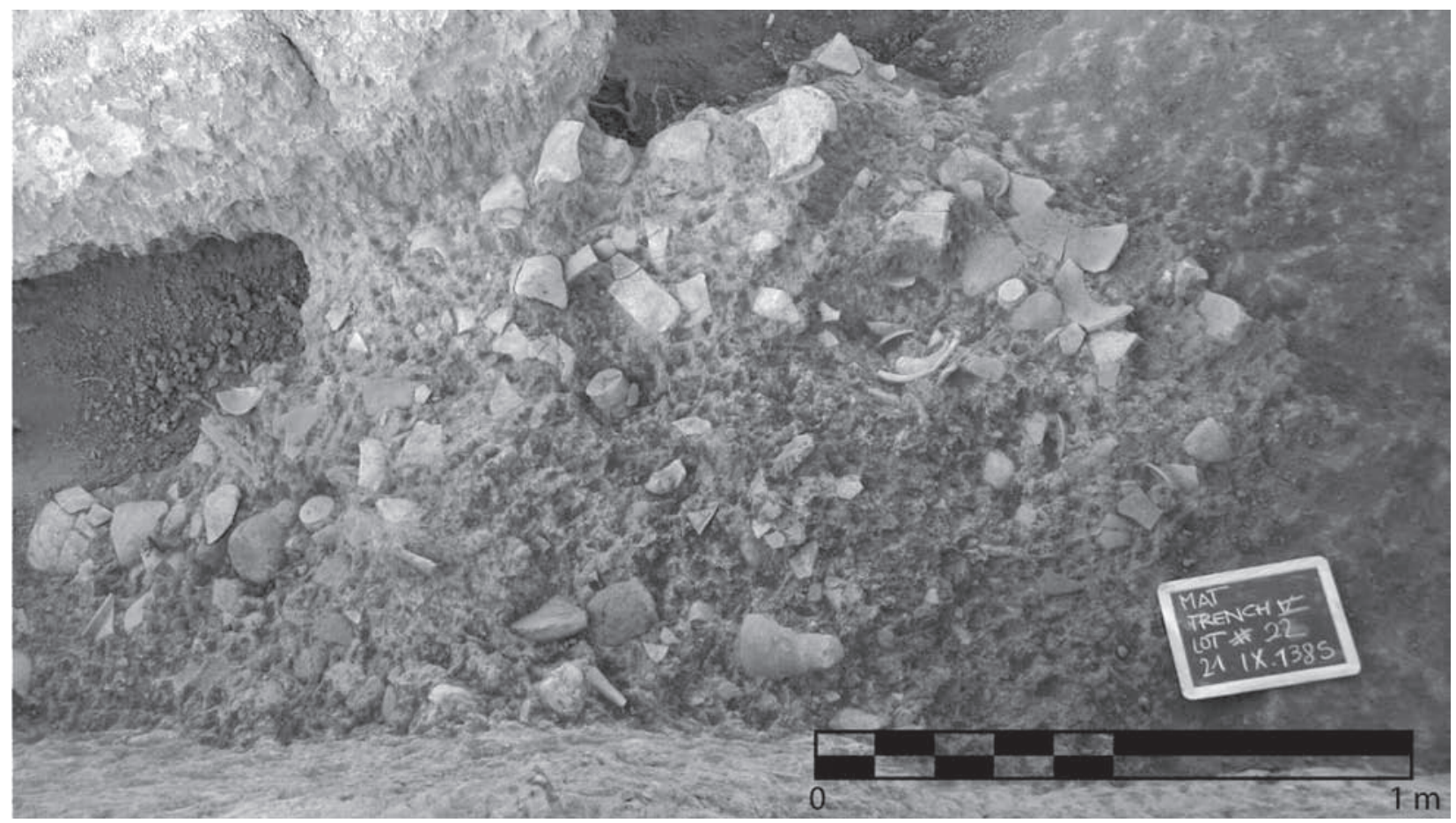

Fig. 8. Mahtoutabad: a detail of the excavated deposit, with fragments of bevel-rim bowls, flowerpots, coarse low-sided trays, spouts and globular jars coming to light. (Image M. Vidale.) 

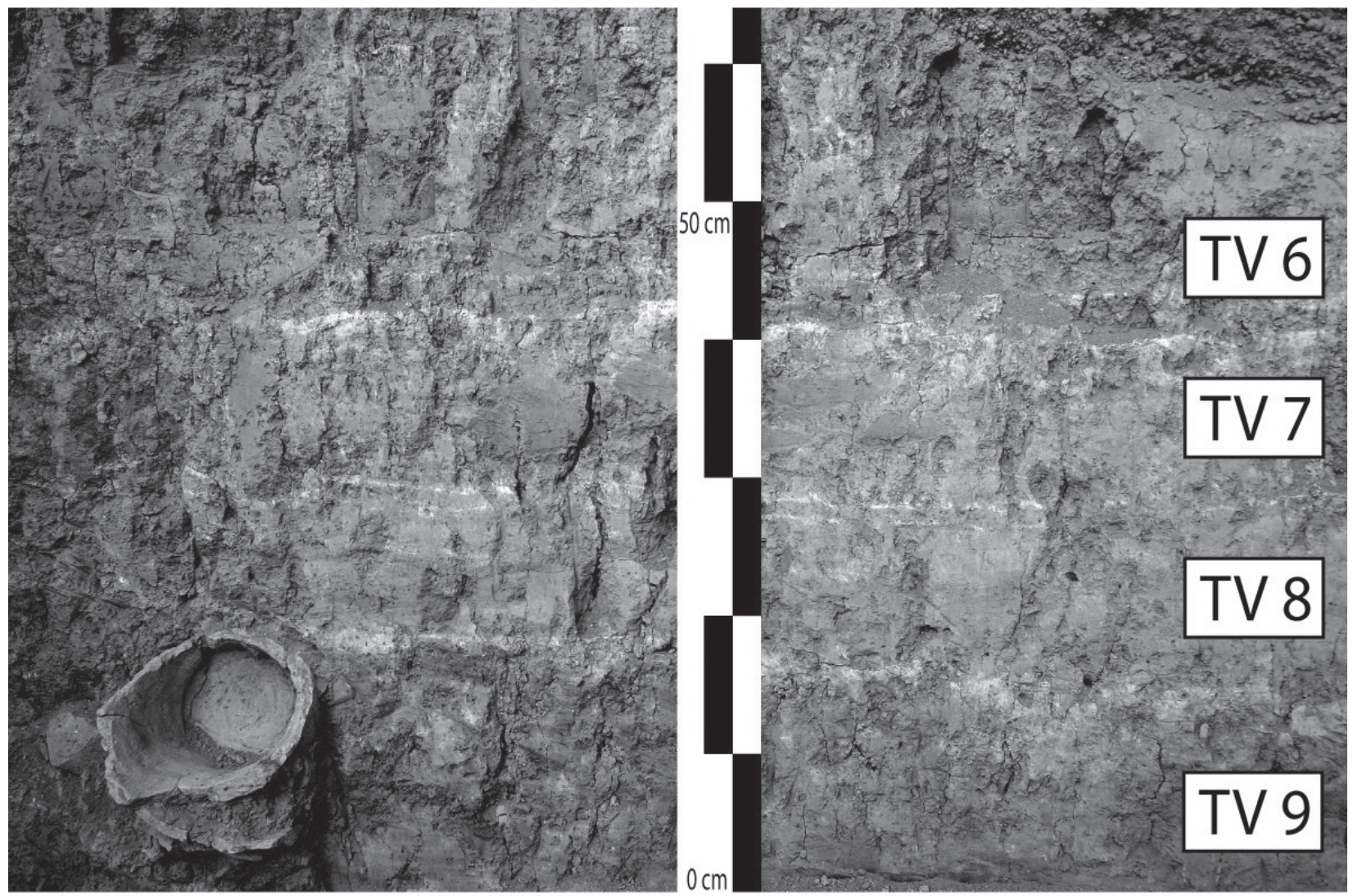

Fig. 9. Mahtoutabad: detail of the main section of Trench V, showing the rhythmic alternation of flood deposit (darker) and interruptions of the sedimentation process marked by aeolian films (lighter-coloured layers). The ceramic assemblage discussed in this paper comes from the lowermost horizon (TV-9). (Image M. Vidale and F. Desset.)

In brief, the northern section of Trench $\mathrm{V}$ shows at least three flood events (layers 7, 8 and 9) each followed by dry events that were apparently short lasting. Then a higher energy flow deposited a sandy silt rather than a silty clay (layer 6) on the site, before a new fluvial erosion (layer 4) deposited a few tiny Mahtoutabad II-III sherds.

Unfortunately the total absence of carbonised material prevented any chance of absolute dating for these deposits. As far as the animal bones are concerned, previous attempts at using bones for dating the third-millennium BC graveyard have failed, possibly due to the effects of the local variations of the water table near the Halil Rud bank.

\section{THE POTTERY}

\section{III.1. "Interregional” forms}

Among the most recognisable forms found on the surface after the recent disturbances, within the illegal pits themselves or recovered later during the excavation, were a number of unpainted forms that were immediately visibly akin to material seen in other Uruk-related assemblages at sites in the western and central Iranian plateau and Khuzistan (BRBs, moulded; flowerpots, wheel-thrown; some types of small- and medium-sized jars, including bottles and vessels with down-turned shoulder spouts; a few restricted carinated containers with nose-like applied lugs and other forms; globular jars or pots with handles or lugs; coarse low-sided oval trays). All these types are well known and, with 


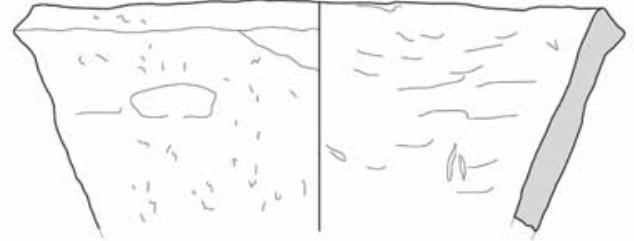

1

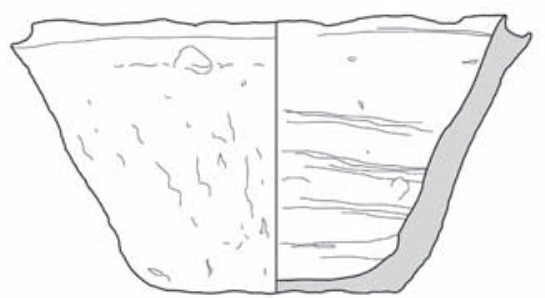

3

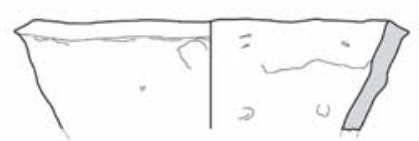

5

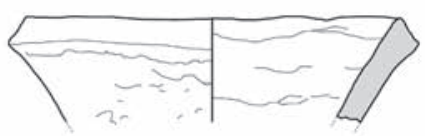

7
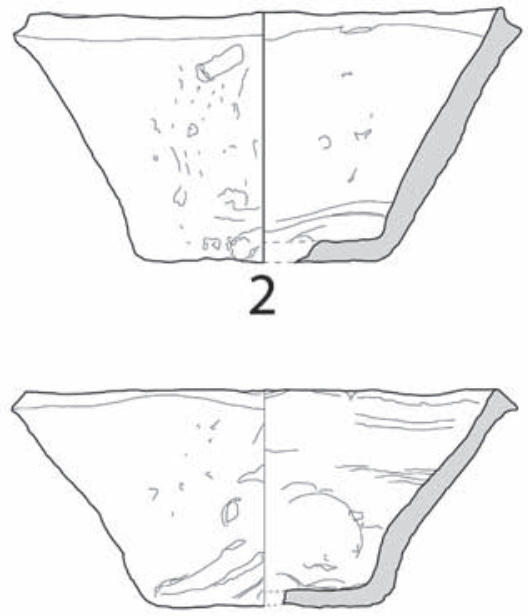

4

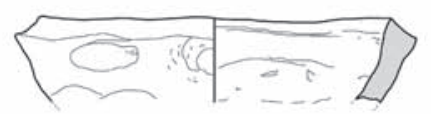

6

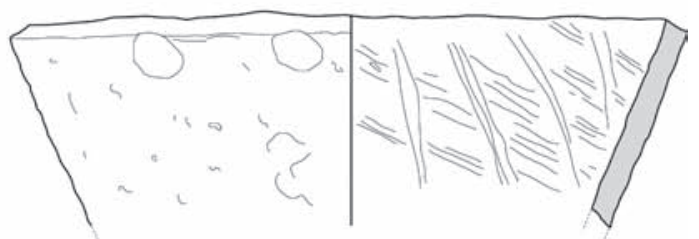

8

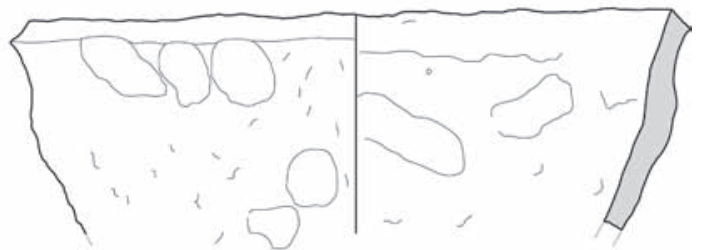

10

9

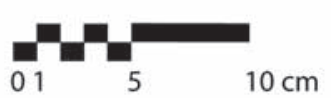

Fig. 10. Bevel-rim bowls I. 1. Trench V, TV-9. Chaff-tempered coarse ware, very pale brown (10 YR 7/3). Mouth diam. 23 cm. 2. Lot 22/272. Chaff-tempered coarse ware, very pale brown (10 YR 7/3). Mouth diam. $20 \mathrm{~cm}$, base diam. $11 \mathrm{~cm}$. 3 . Lot 21/326. Chaff-tempered coarse ware, very pale brown (10 YR 7/4). Mouth diam. $20 \mathrm{~cm}$, base diam. $11 \mathrm{~cm} .4$. Lot 22/274. Chaff-tempered coarse ware, very pale brown (10 YR 7/3). Mouth diam. $20 \mathrm{~cm}$, base diam. $11 \mathrm{~cm}$. 5. Lot 16/208. Chafftempered coarse ware, light grey (10 YR 7/2). Mouth diam. $16 \mathrm{~cm}$. 6. Lot 16/152. Chaff-tempered coarse ware, very pale brown (10 YR 7/3). Mouth diam. $16 \mathrm{~cm}$. 7. Lot 16/153. Chaff-tempered semi-coarse ware, very pale brown (10 YR 7/4). Mouth diam. $18 \mathrm{~cm}$. 8. Trench V, TV-9. Chaff-tempered coarse ware, very pale brown (10 YR 7/4). Mouth diam. $27 \mathrm{~cm} .9$. Trench V, TV-9. Chaff-tempered coarse ware, light yellowish brown (10 YR 6/4). Mouth diam. $30 \mathrm{~cm} .10$. Trench V, TV-9. Chaff-tempered coarse ware, very pale brown (10 YR 7/4). Mouth diam. $27 \mathrm{~cm}$. (Image M. Vidale and F. Desset.) 

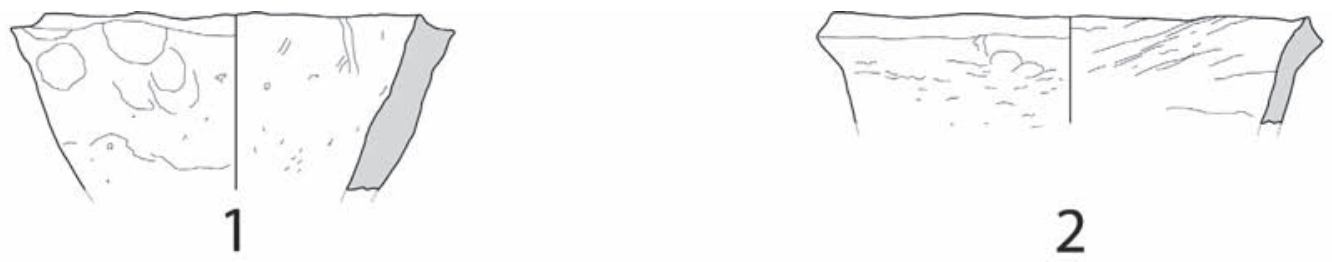

2
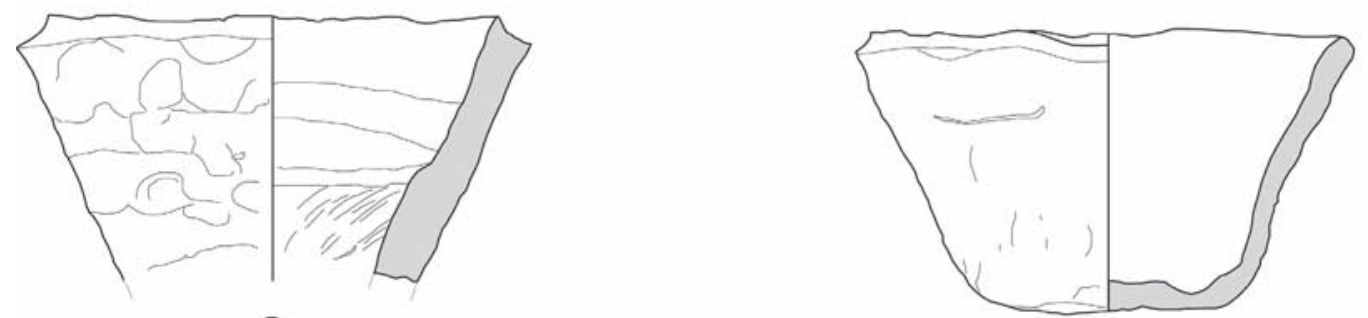

3
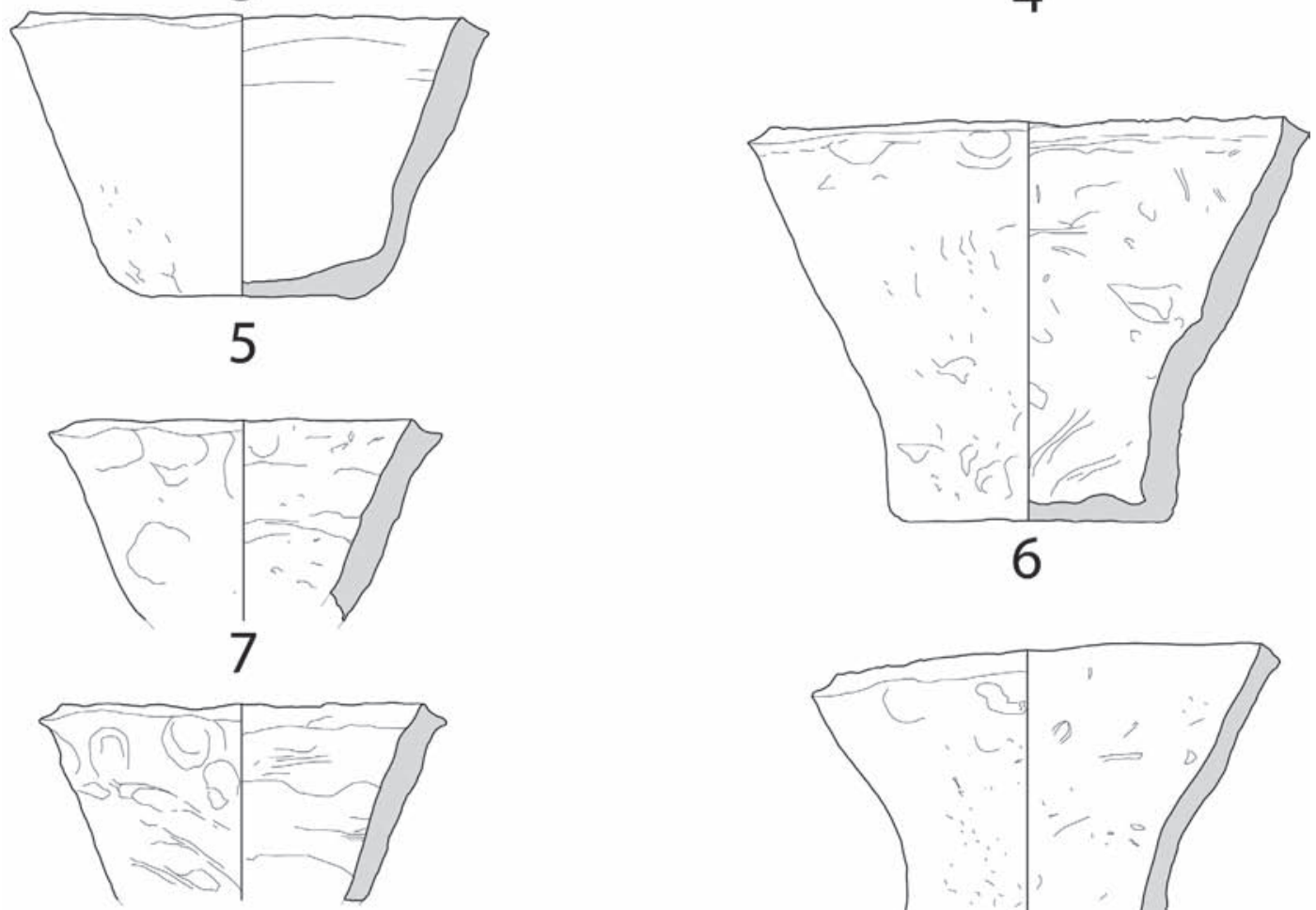

8
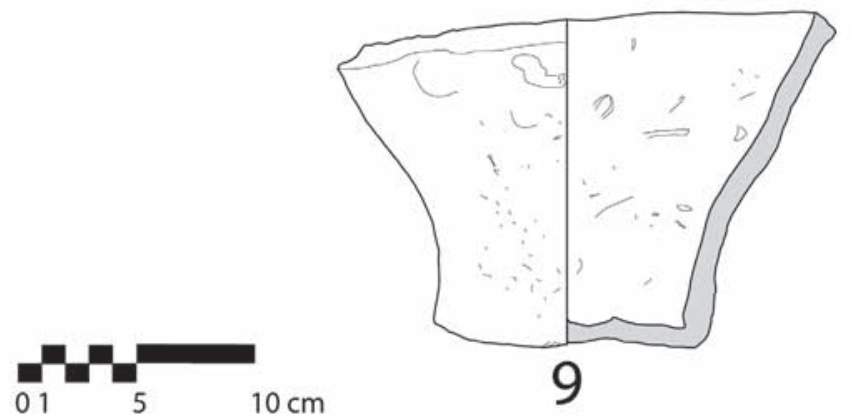

Fig. 11. Bevel-rim bowls II. 1. Trench V, TV-9. Chaff-tempered coarse ware, very pale brown (10 YR 7/3). Mouth diam. 16 cm. 2. Trench V, TV-9. Chaff-tempered coarse ware, light brownish grey (10 YR 6/2). Mouth diam. $20 \mathrm{~cm}$. 3. Trench V, TV-9. Chaff-tempered coarse ware, very pale brown (10 YR 7/4). Mouth diam. $19 \mathrm{~cm}$. 4. Lot 21. Chaff-tempered coarse ware, very pale brown (10 YR 7/4). Mouth diam. $24 \mathrm{~cm}$. 5. Lot 21/328. Chaff-tempered coarse ware, very pale brown (10 YR 7/3). Mouth diam. $19 \mathrm{~cm}$, base diam. $9 \mathrm{~cm}$. 6. Trench V, TV-9/283. Chaff-tempered semi-coarse ware, pale brown (10 YR 6/3). Mouth diam. $23 \mathrm{~cm}$, base diam. $13 \mathrm{~cm}$. 7. Lot 16/154. Chaff-tempered semi-coarse ware, pink (7.5 YR 7/4). Mouth diam.

$16 \mathrm{~cm}$. 8. Lot 16/155. Chaff-tempered semi-coarse ware, pink (7.5 YR 7/4). Mouth diam. $16 \mathrm{~cm} .9$. Trench V, TV-9/290. Chaff-tempered coarse ware, very pale brown (10 YR 7/4). Mouth diam. $19 \mathrm{~cm}$, base diam. $10 \mathrm{~cm}$. (Image M. Vidale and F. 
TABLE 1. Size of BRBs (reconstructed mouth diameters).

\begin{tabular}{|c|c|}
\hline Mouth diameter (2 cm interval) & Quantity \\
\hline $14-15$ & 4 \\
\hline $16-17$ & 5 \\
\hline $18-19$ & 20 \\
\hline $20-21$ & 42 \\
\hline $22-23$ & 38 \\
\hline $24-25$ & 26 \\
\hline $26-27$ & 9 \\
\hline $28-29$ & 6 \\
\hline $30-31$ & 5 \\
\hline $32-33$ & 1 \\
\hline $34-35$ & - \\
\hline $36-37$ & 2 \\
\hline
\end{tabular}

some exceptions, have been consistently described and labelled in excavation reports. The same basic and standard names will be used here, and more detailed descriptions will be reserved for particular forms and variants, or to unusual vessels.

The mouth diameter of 158 BRBs and fragments (both from surface and excavated deposits) could be measured on the horizontal tangency plane, from the interior (Figs. 10, 11, 12 and 13). Admittedly, their mouth contour is so irregular that the exercise may be considered, at best, optimistic but Table 1 (where, because of this irregularity, the measurements come in 2-cm intervals) shows that the bulk of the BRBs had mouth diameters ranging from 18 to $25 \mathrm{~cm}$, with a limited series of very small specimens between 14 and 17, and an equally limited group of larger vessels (large at the mouth from 26 to $37 \mathrm{~cm}$ ). The smaller BRBs are often squat, while the largest ones tend to be quite tall, probably because the height was more variable than the other dimensions. Table 2 shows that the diameters at the base, when preserved, can be measured with more precision and vary primarily from 9 to $13 \mathrm{~cm}$.

The importance of BRBs in the "contemporary" published assemblages is quite variable. For example, their frequency in the Mahtoutabad sample (c. 13\%$14 \%$, see below) cannot be compared with the enormous quantities reported at Chogha Mish. ${ }^{4}$ At Godin Tepe, BRBs are likely to represent around $20-30 \%$ of the pottery from Period VI. ${ }^{5}$ The frequency of BRBs

4 Delougaz and Kantor 1996: 50.

5 This approximate value is inferred from Rothman and Badler 2011: 86, when they report that at Godin Tepe Period VI, small bowls $(<24 \mathrm{~cm})$ amount to about $58 \%$ of the total, and that within this group BRBs are the most
TABLE 2. Size of the bases of BRBs (reconstructed diameters).

\begin{tabular}{|c|c|}
\hline Base (external) cm & Quantity \\
\hline $9 \mathrm{~cm}$ & 11 \\
\hline $10 \mathrm{~cm}$ & 15 \\
\hline $11 \mathrm{~cm}$ & 21 \\
\hline $12 \mathrm{~cm}$ & 18 \\
\hline $13 \mathrm{~cm}$ & 10 \\
\hline $14 \mathrm{~cm}$ & 5 \\
\hline $15 \mathrm{~cm}$ & 2 \\
\hline
\end{tabular}

at Mahtoutabad is slightly higher than in Arisman $(9 \%),{ }^{6}$ but six times higher than at Banesh period Tal-e Malyan (c. $2 \%){ }^{7}$ The Mahtoutabad frequency is also apparently much higher than in the IVC building and later levels at Tepe Yahya. ${ }^{8}$

In terms of size and form, the Mahtoutabad BRBs also show some differences to those from other sites. At Tepe Farukhabad, although the distribution of mouth diameters is somewhat similar to Mahtoutabad with very rare small specimens (up to $15 \mathrm{~cm}$ ), equally rare larger ones $(30-31 \mathrm{~cm})$ and a norm between 16 and $23 \mathrm{~cm}$, on average these containers are slightly smaller than those found at our site (c. 19.5 vs. 22 $\mathrm{cm})$, and this is confirmed by the mean diameters of the bases $(c .8 .3 \mathrm{~cm}$ vs. $11.3 \mathrm{~cm})$. The BRBs published from Tepe Yahya are definitely smaller, and the main mouth diameters at Arisman vary from 14 to $20 \mathrm{~cm} .{ }^{9}$ The taller BRB variety might also be on record at both sites. ${ }^{10}$ Moreover, the largest BRBs at Tepe Farukhabad, those published in the Chogha Mish

common form; the group, however, includes another four categories of small bowls.

6 Helwing 2011a: 213, fig. 35, 201-203.

7 Sumner 2003: 43.

8 Potts D.T. 2001: 59, fig. 2.19.A, B.

9 Potts D.T. 2001: fig. 2.19.A, B; Helwing 2011a: 247, fig. 35, 201-203.

10 "Both a smaller and a taller variety have been discovered (at Tepe Yahya) which have parallels at Susa" (Lamberg-Karlovsky and Tosi 1973: 36; see Potts D.T. 1977: 28, n. 30). The Susa parallel is with a tall flowerpot published in Le Brun 1978a: fig. 34, 3, and should not be related to BRBs. The confusion between wheel-thrown flowerpots and tall moulded BRBs is present in other articles (e.g. Rothman and Badler 2011). 


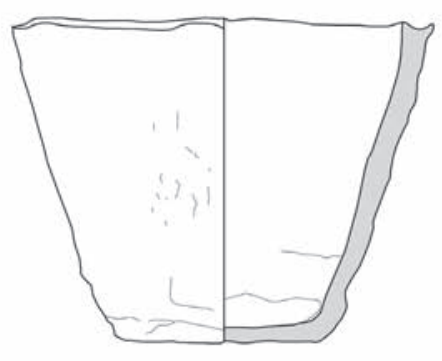

1

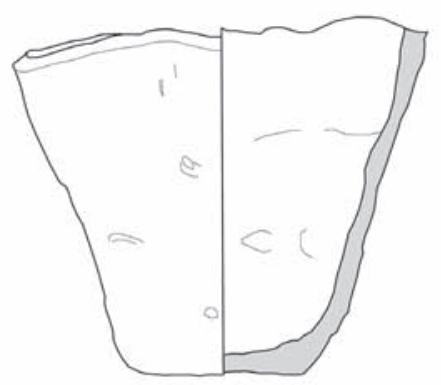

4

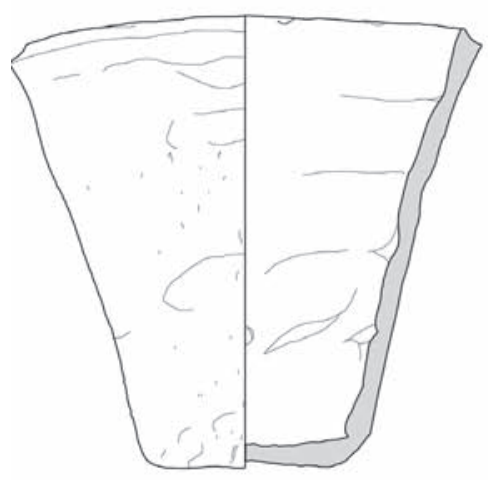

7

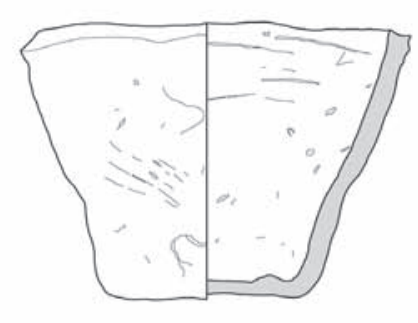

2

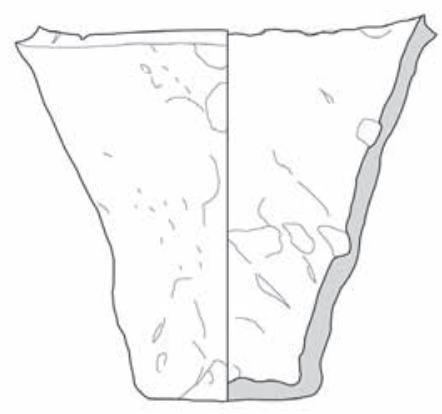

5

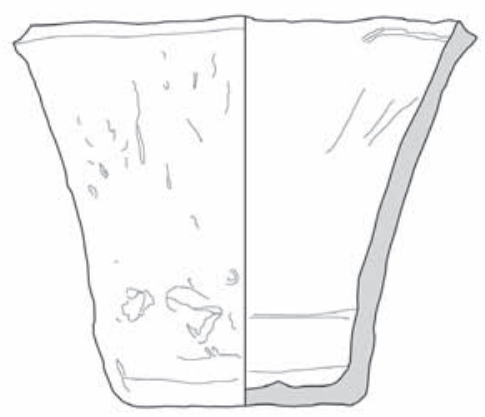

8

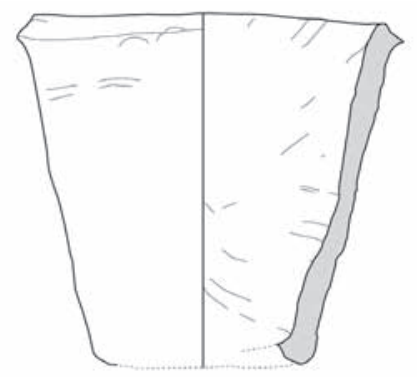

3

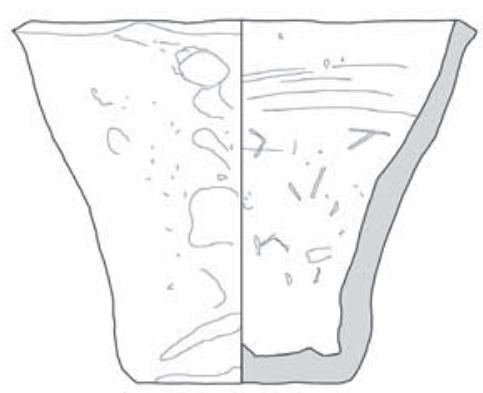

6

Fig. 12. Bevel-rim bowls III. 1. Lot 22. Chaff-tempered coarse ware, very pale brown (10 YR 7/4). Mouth diam. $19 \mathrm{~cm}$, base diam. $11 \mathrm{~cm}$. 2. Lot 22/288. Chaff-tempered coarse ware, light brownish grey (10 YR 6/2). Mouth diameter $17 \mathrm{~cm}$, base diam. $10 \mathrm{~cm}$. 3. Trench V, TV-9. Chaff-tempered coarse ware, very pale brown (10 YR 7/3). Mouth diam. $18 \mathrm{~cm}$, base diam. $10.5 \mathrm{~cm}$. 4. Lot 21. Chaff-tempered coarse ware, light grey (10 YR 7/2). Mouth diam. $20 \mathrm{~cm}$, base diam. $9 \mathrm{~cm} .5$. Lot 22/203. Chaff-tempered coarse ware, very pale brown (10 YR 7/3). Mouth diam. $21 \mathrm{~cm}$. 6. Lot 22/289. Chaff-tempered coarse ware, very pale brown (10 YR 7/3). Mouth diam. $22 \mathrm{~cm}$, base diam. $11 \mathrm{~cm}$. 7. Lot 21. Chaff-tempered coarse ware, light yellowish brown (10 YR 6/4). Mouth diam. $22.5 \mathrm{~cm}$, base diam. $11 \mathrm{~cm}$. 8 . Lot 22/291. Chaff-tempered coarse ware, pale brown (10 YR 6/3). Mouth diam. $22 \mathrm{~cm}$, base diam. $12 \mathrm{~cm}$. (Image M. Vidale and F. Desset.) 


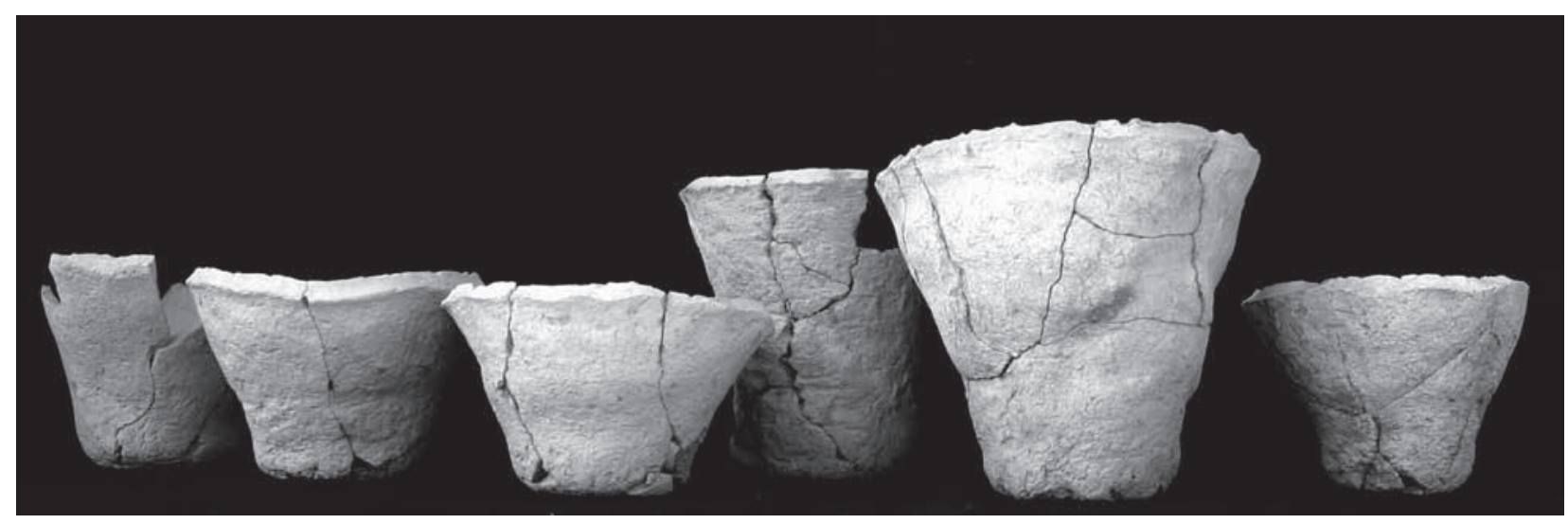

Fig. 13. Mahtoutabad: A group of bevel-rim bowls showing the formal and dimensional variability of the type. (Image M. Vidale.)

report ${ }^{11}$ and one of the largest found in Arisman, ${ }^{12}$ are all shallow rather than tall. 13

Flowerpot fragments are not uncommon in the Mahtoutabad III collection (Fig. 14). They are tall and slender, with restricted string-cut bases and an overall flaring contour. The inner wall often shows the continuous spiral-like rill that indicates wheel throwing, and rims are slightly thickened and projected toward the inside of the mouth. The base material is a low-fired clay tempered with finer chaff particles, which is slipped red-orange. No complete specimen was found, and most flowerpots had bases 10-11 cm wide, with mouth diameters of $18-20 \mathrm{~cm}$ or more, and a height wavering around $25 \mathrm{~cm}$ or more. Vessels of this type have been recorded at Tepe Farukhabad, Tal-e Malyan and Tal-e Nurabad, 14 but were not found at Chogha Mish, Godin Tepe, Arisman or Tepe Yahya. At Tepe Farukhabad, a more common variant of the same class of vessels, distinguished by a narrow and tapering solid base, which was also recorded at Tal-e Malyan but not at Mahtoutabad, was used in the most elaborate buildings. ${ }^{15}$

Figure 15 shows a group of different types of restricted vessels. The restricted jar shown in Figure

11 Delougaz and Kantor 1996: pl. 83, F-V.

12 Helwing 2011a: 247, fig. 35.200.

13 " [...] the large deep form attested in Susa Acropole I, Level 17 [...] is not known in Farukhabad" (Wright 1981: 128 and 329).

14 For Tepe Farukhabad, seeWright 1981: fig. 45, e. For Tal-e Malyan see the rims in Sumner 2003: figs. 21, a-u; 22 r, uaa; three flowerpots in pl. 15 look identical to the Mahtoutabad III specimens.

15 Wright 1981: 178.
15.1 was distinguished by a short sub-vertical rim and sloping shoulder, and only resembles some specimens from Chogha Mish"16 and the "Everted Collar Necked Jars" described at Godin Tepe. 17

Figure 15.2 shows the distinctive neck of a type of bottle with a slender elongated body and a downward-bent spout on the shoulder. At Chogha Mish ${ }^{18}$ and other sites, these vessels are from 35 to more than $80 \mathrm{~cm}$ tall, about $15 \mathrm{~cm}$ wide and there is little doubt that they were used to transport, store and pour valuable liquids. The type is also reported at Tepe Farukhabad, 19 Susa Acropole I, levels 18-17,20 and Tepe Sialk IV. ${ }^{21}$ A small number of spouts of the same type were unearthed in the Oval complex of Godin Tepe, Period VI,22 but so far not at any other site in the Kerman region. The thick cone-shaped bottoms shown in Figure 15.5-6, which are distinguished by an extensive horizontal scraping caused by turning on the potter's wheel, probably belong to the same elongated containers. The spouts shown in Figure 15.8, 10 and 11 might also have been detached from similar forms, or from the squatter pots and shorter restricted jars that are well illustrated in the Chogha Mish report. ${ }^{23}$

Figure 15.3 shows the concave neck of a restricted jar. Although scarcely diagnostic, this fragment can

16 Delougaz and Kantor 1996: pls. 101, L; 103, D-F.

17 Rothman and Badler 2011: fig. 4.49.

18 Delougaz and Kantor 1996: pl. 111.

19 Wright 1981: fig. 54, a-c.

20 Le Brun 1978a: fig. 30 and pl. XIX, nos. 7-8.

21 Ghirshman 1938/1939: pl. LXXXIX, S. 43d.

22 Rothman and Badler 2011: fig. 4.50.

23 Delougaz and Kantor 1996: pls. 104-110. 

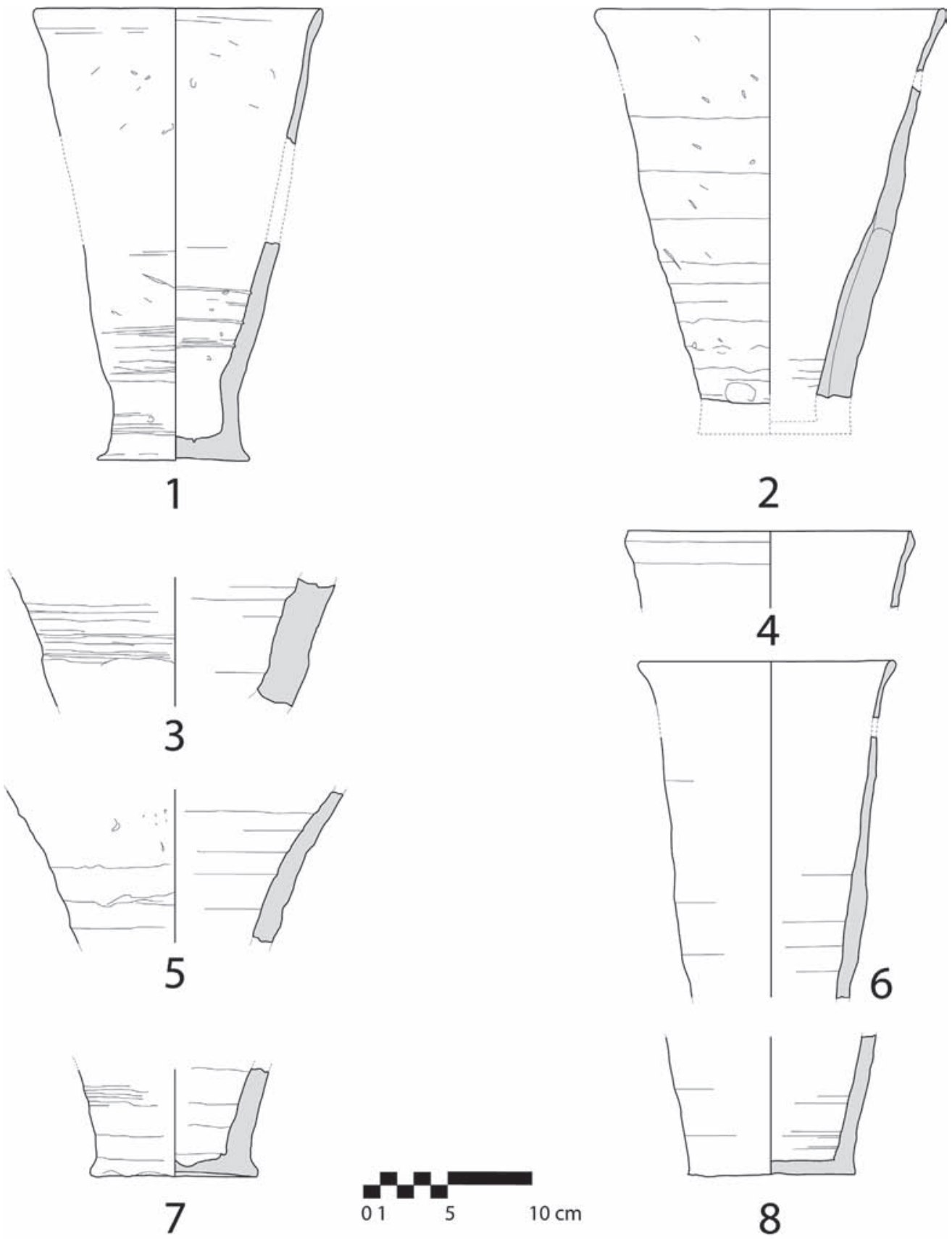

Fig. 14. Flowerpots. 1. Lot 21/325. Chaff-tempered coarse ware, white (10 YR 8/2). Mouth diam. $17 \mathrm{~cm}$, base diam. $9 \mathrm{~cm}$. 2. Lot 22/287. Chaff-tempered coarse ware, light grey (10 YR 7/2). Mouth diam. $26 \mathrm{~cm}$, base diam. $12 \mathrm{~cm}$. 3. Lot 16/181. Semi-coarse, sand-tempered ware, pale brown (10 YR 6/3). 4. Lot 22/314. Coarse ware, tempered with chaff and mica, light yellowish brown (10 YR 6/4). Mouth diam. $17 \mathrm{~cm}$. 5. Lot 16/182. Chaff-tempered medium ware, light brown (7.5 YR 6/4). 6. Trench V, TV-9. Chaff-tempered coarse ware, pale brown (10 YR 6/3). Mouth diam. $16 \mathrm{~cm}$. 7. Lot 16/183. Chaff-tempered coarse ware, light brown (7.5 YR 6/4). Base diam. $6.5 \mathrm{~cm}$. 8. Lot 22/304. Coarse ware including chaff articles and mica, light yellowish brown (10 YR 6/4). Base diam. $10 \mathrm{~cm}$. (Image M. Vidale and F. Desset.) 

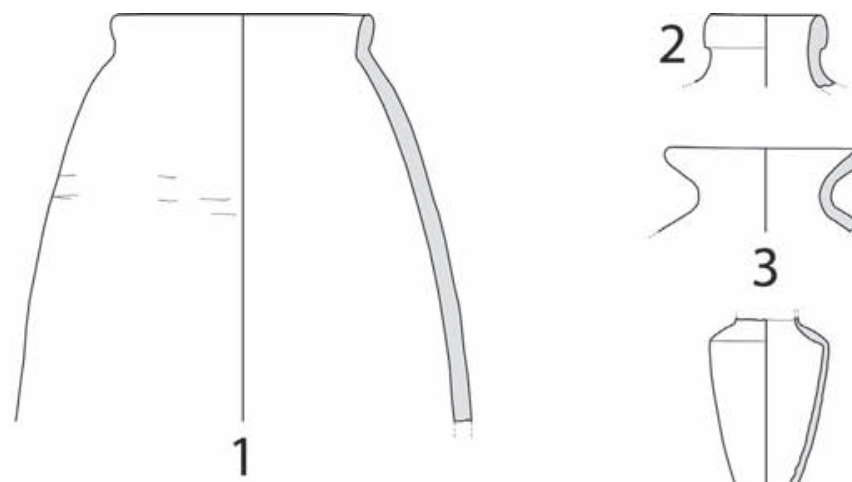
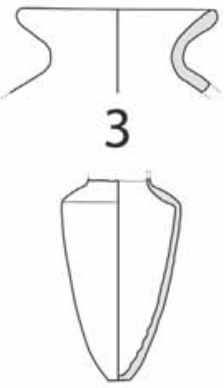

4
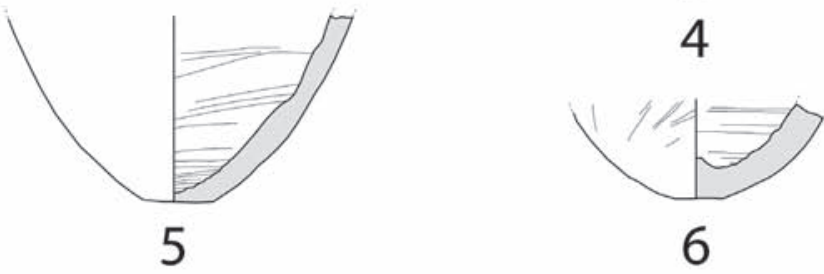

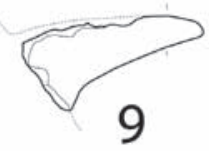

Y

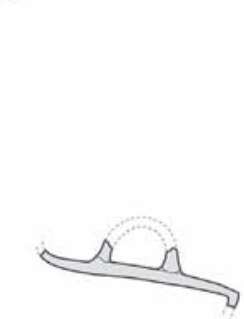

12
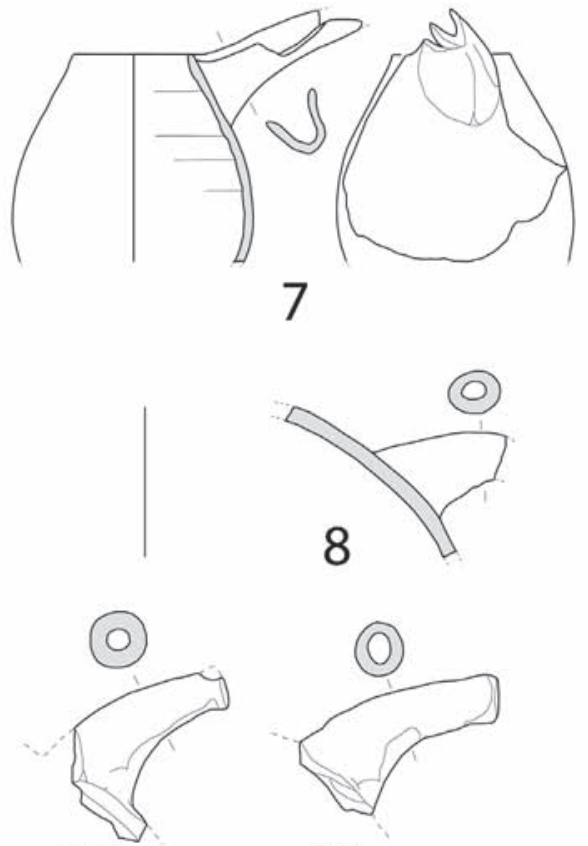

10

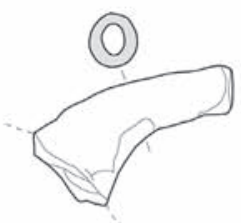

11
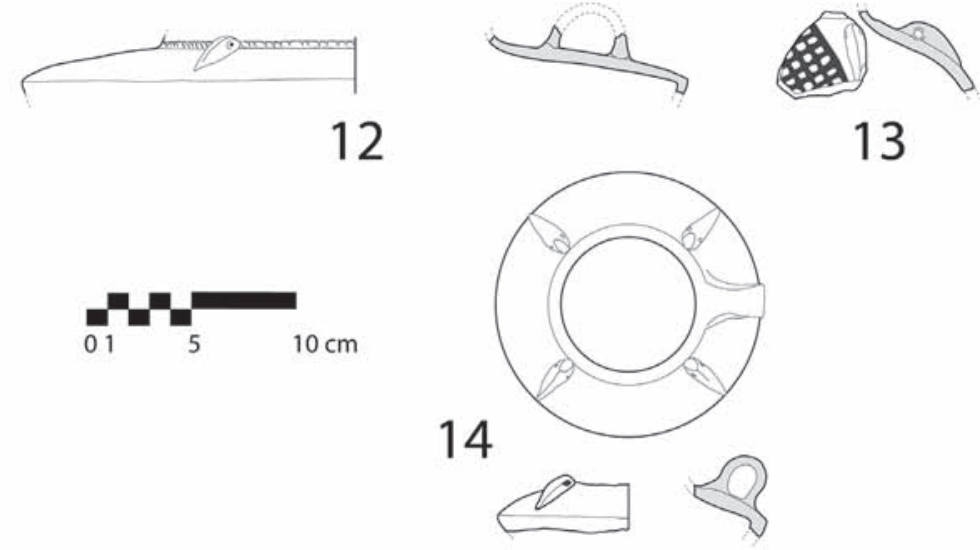

13

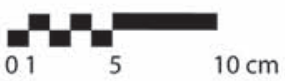

Fig. 15. Tall restricted, spouted and lugged jars. 1. Lot 22/342. Semi-fine ware, with sand and mica particles, pink (7.5 YR 7/4). Mouth diam. $10 \mathrm{~cm}$. 2. Trench V, TV-9. Fine ware without visible inclusions, pale brown (10 YR 6/3). Mouth diam. 4.5 $\mathrm{cm}$. 3. Trench V, TV-9. Fine ware without visible inclusions, very pale brown (10 YR 7/4). Mouth diam. $5 \mathrm{~cm} .4$. Trench V, TV-9, Lot 23. Fine ware without visible inclusions, reddish yellow (7.5 YR 7/6), slipped brown (7.5 YR 5/6). 5. Lot 19/252. Coarse ware, chaff-tempered, pink (7.5 YR 7/4), mat impression on the base. 6. Lot 19/251. Coarse ware, chaff-tempered, pinkish grey (7.5 YR 7/2). Base diam. $4 \mathrm{~cm}$. 7. Lot 22. Medium-fine ware, pink (7.5 YR 7/4). Mouth diam. $7 \mathrm{~cm} .8$. Lot 22/342. Medium-fine ware with a micaceous temper, pink (7.5 YR 7/4). 9. Lot 22/217. Medium-fine ware, sand-tempered, pale red (10 R 6/2). 10. Lot 22. Medium-fine ware, finely sand-tempered, pinkish grey (7.5 YR 7/2). 11. Lot 22. Medium-fine ware, pink (7.5 YR 7/4). 12. Trench V, TV-9. Medium-fine ware, pale brown (10 YR 6/3), with residues of a red pigment on the shoulder. The nose-lug was originally painted black. 13. Trench V, TV-9. Medium ware, sand-tempered, very pale brown (10 YR 7/4), painted very dark grey (2.5 Y 3/0). 14. Trench V, TV-9. Medium-coarse ware, sand-tempered, brownish yellow (10 YR 6/6), slipped red (2.5 YR 5/8). (Image M. Vidale and F. Desset.) 
be compared to a very similar specimen from Tepe Yahya, as well as with a couple of restricted jars at Arisman, and possibly also with a small decorated jar found at Chogha Mish. ${ }^{24}$

Figure 15.4 shows a fine miniature jar made on the potter's wheel and covered with a bright red slip. It may be compared with variable confidence with some small jars found at Chogha Mish ${ }^{25}$ where this form was also reproduced in limestone, ${ }^{26}$ suggesting that these vessels contained cosmetics or other valuable substances.

Figure 15.9 shows a rim spout distinguished by a slightly curved profile and a V-shaped section. The only vessel with this type of spout with a preserved form is illustrated in Figure 15.7-a small pear-shaped jar. Note how the spout is set on the rim with a left twist, and not symmetrically, which is a feature shared by the other identical spouts recovered in the Mahtoutabad III assemblage. While a similar form was found at Tal-e Malyan, some identical spouts were found in the nearby sites of Tal-e Kureh,27 in IVC levels at Tepe Yahya, 28 at Tal-i Iblis IV29 and at Tol-e Nurabad Phase A9. ${ }^{30}$ Small restricted jars with similar rim spouts and perhaps comparable functions were found at Arisman, but the walls are much thicker and the body in the majority of the cases is distinctively biconical. ${ }^{31}$ The same type was identified in late fourth-millennium BC contexts at Tepe Sialk IV. ${ }^{32}$

The three fragments of nose-lugged jars shown in Figure 15.12-14 and Figure 16 bring us immediately westwards to Susiana. The Figure 15.12 example shows a fine medium-sized jar with thin walls, a strongly carinated shoulder and probably a cylindrical neck, with remnants of nose lugs and the attachment of a strap vertical handle. The shoulder has faint traces of a red wash above and below the ridge, while the nose lug seems to have been painted black. The litthe that remains is reminiscent of some vessels in the

24 Potts D.T. 2001: fig. 1.6.C; Helwing 2011a: 234, fig. 22. 91 and 92; Delougaz and Kantor 1996: pl. 89, T. The general form can perhaps be hypothesised after specimens in pl. 90 , $\mathrm{A}-\mathrm{D}$, in the same volume.

25 Delougaz and Kantor 1996: pls. 88 and 89, esp. pl. 89, L.

26 Delougaz and Kantor 1996: pl. 125, H.

27 Sumner 2003: fig. 23, j; D8, 2-3.

28 Potts D.T. 2001: figs. 1.6.F, 1.10, 1.54.A.

29 Caldwell 1967: fig. 40, 1 and 2.

30 Weeks et al. 2009: fig. 3.105, TNP610, TNP634.

31 Helwing 2011a: 238, fig. 26.

32 Ghirshman 1938/1939: pls. XXVI and LXXXVIII. ceramic assemblage of Chogha Mish, 33 which also appear in very elaborate versions. Delougaz and Kantor compared the type to finds from Habuba Kabira, Tello, Tal-e Malyan and Susa Acropole I.17B, where the vessel was also carved in stone. ${ }^{34}$ The vessel shown in Figure 15.13 is even smaller, but can be ascribed to a small- to medium-sized sub-globular jar with nose lugs on the shoulder and a painted frieze of hatched triangles running at the same height. There are similar specimens from Chogha Mish although the decoration is incised rather than painted. ${ }^{35}$ At Tepe Farukhabad, however, a four nose-lugged sub-globular jar with the same painted frieze of hatched triangles looks exactly like the Mahtoutabad specimen. ${ }^{36}$ The third fragment, shown in Figure 15.14, belongs to a small biconical squat-necked jar with four nose lugs and a single upraised flat handle. In this case the comparison with Chogha Mish is even more faithful. ${ }^{37}$

The painted necked carinated jars found in late fourth-millennium BC contexts at Tepe Yahya ${ }^{38}$ share the nose-lugs on the shoulder, but have more restricted contours, and are painted in broad bands of superimposed friezes below the shoulder, which is left plain. At Arisman, while forms and decorative patterns seem closer to western models, some of the friezes, as at Tepe Yahya, run along the maximum expanse of the jars rather than on the shoulder. ${ }^{39}$ At Godin Tepe, while the majority of the four-lugged necked jars look identical to those of Chogha Mish in that they are a decoration with friezes of triangles running on the shoulder between the nose-lugs, at least one is painted on a red slip and resembles the Tepe Yahya and Arisman specimens, which have a broad geometric band at the maximum expanse. .40 Generally, at these sites there are variants that look like local products adapted to "interregional" fashion, rather than western vessels that are either imported or locally made.

Figure 17 shows a group of globular or sub-globular

33 Delougaz and Kantor 1996: pl. 115, D and E.

34 Delougaz and Kantor 1996, I, 89 n. 123, fig. 14.

35 Delougaz and Kantor 1996: various specimens in pls. 112114. See also pl. 122, in particular for the hatched triangles (specimens A, B, G, H). In every case, the incised friezes run at the same height of the lugs and include these applied elements in the decoration.

36 Wright 1981: fig. 57 d.

37 Delougaz and Kantor 1996: pl. 115, A, B.

38 Potts D.T. 2001: figs. 1.40, 1.43, 2.6, 3.13.

39 Helwing 2011a: figs. 14. 1 and 13; 19. 61; 20.70; 21.

40 Rothman and Badler 2011: fig. 4.47. 


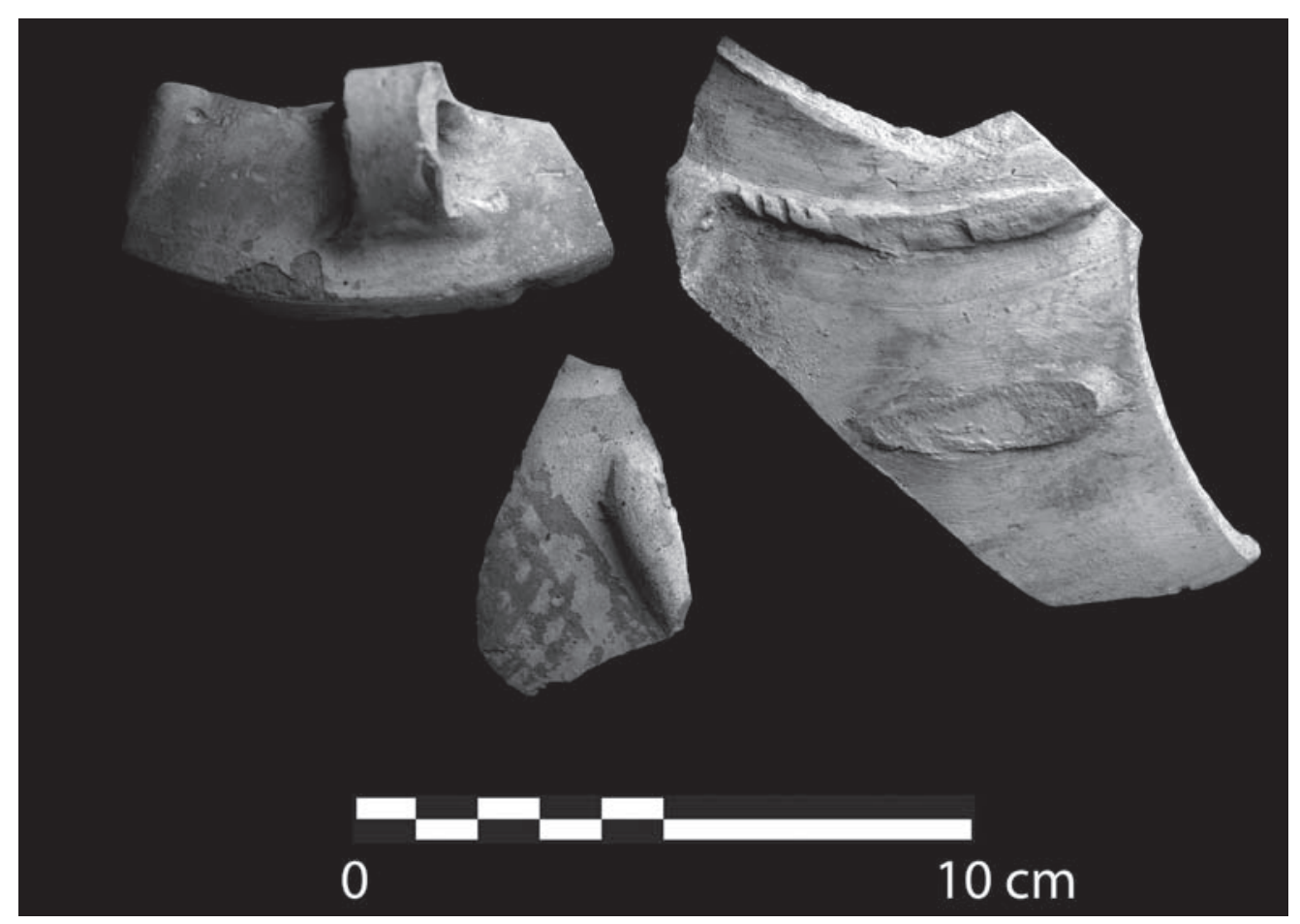

Fig. 16. Mahtoutabad: fragments of nose-lugged jars. (Image M. Vidale.)

jars and similar types. Figure 17.1-8 illustrates one of the most common forms found in the Mahtoutabad III deposits, a plain globular pot with a short, round everted rim. The distribution of the mouth diameter values, in spite of the limited number of measurements, suggests an assemblage of medium-sized pots or jars in two size clusters, one around 15-19 cm, the other wavering between 21 and $24 \mathrm{~cm}$. Many of these pots have a pattern of multiple parallel grooves running on the shoulder, combed when the clay was plastic, and a vertical flat or strap handle joining the rim to the base of the shoulder (see Fig. 17.3). Standard versions of this type are very common at sites in Susiana, ${ }^{41}$ and other secondary attributes such as the horizontal twisted handle (Fig. 17.5) 42 or the cross-hatched incised patterns (Fig. 17.7) ${ }^{43}$ stress a strong connection with the west.

41 Delougaz and Kantor 1996: pls. 95, F-N; 96; some variants in pls. 97-98; for Tepe Farukhabad, see Wright 1981: fig. 50 , a and $55, \mathrm{j}$.

42 Delougaz and Kantor 1996: pl. 101, A-G, I, J; vertical twisted handles appear on the same vessels in pl. 100; the same variant at Tepe Farukhabad, in Wright 1981: fig. 55, $\mathrm{k}, 1$.

43 Delougaz and Kantor 1996: pls. 97, D; 98, J, K, I; 100, F; 101, E.
These vessels, which appear to be so important at Chogha Mish and Mahtoutabad, are completely absent at Tepe Yahya and Tal-e Malyan. At Arisman, simple globular pots of the same general form are common, and the handle is applied in the same position, ${ }^{44}$ but its section, as a rule, is round rather than flat and the shoulder is always plain. At Godin Tepe, singlehandled globular pots, called "beer jars", 45 might represent the same type and functions, but they bear notched ridges in relief instead of incised lines, and the thick handles resemble those of the Arisman handled pots. The forms of Godin Tepe and Arisman look like a local re-elaboration of an interregional model.

Figure 17.9-15 shows elements of globular pots and/or jars, which cannot be commented on in greater detail. Figure 17.16-17 are small biconical jars, a rather uncommon form in the inventories so far reviewed, with the possible exception of the pitchers with rim spouts. ${ }^{46}$ The small hole-mouth jar shown in Figure 17.18 is very similar to a vessel found at Aris-

44 Helwing 2011a: 229, 230, figs. 17 and 18.237; fig. 25.110, $111,114,115$ and $118-120$.

45 Rothman and Badler 2011: fig. 4.50.

46 For example, for Tal-e Malyan, see Sumner 2003: fig. 26, h, j; for Arisman, see Helwing 2011a: 238, fig. 26.131-136. 

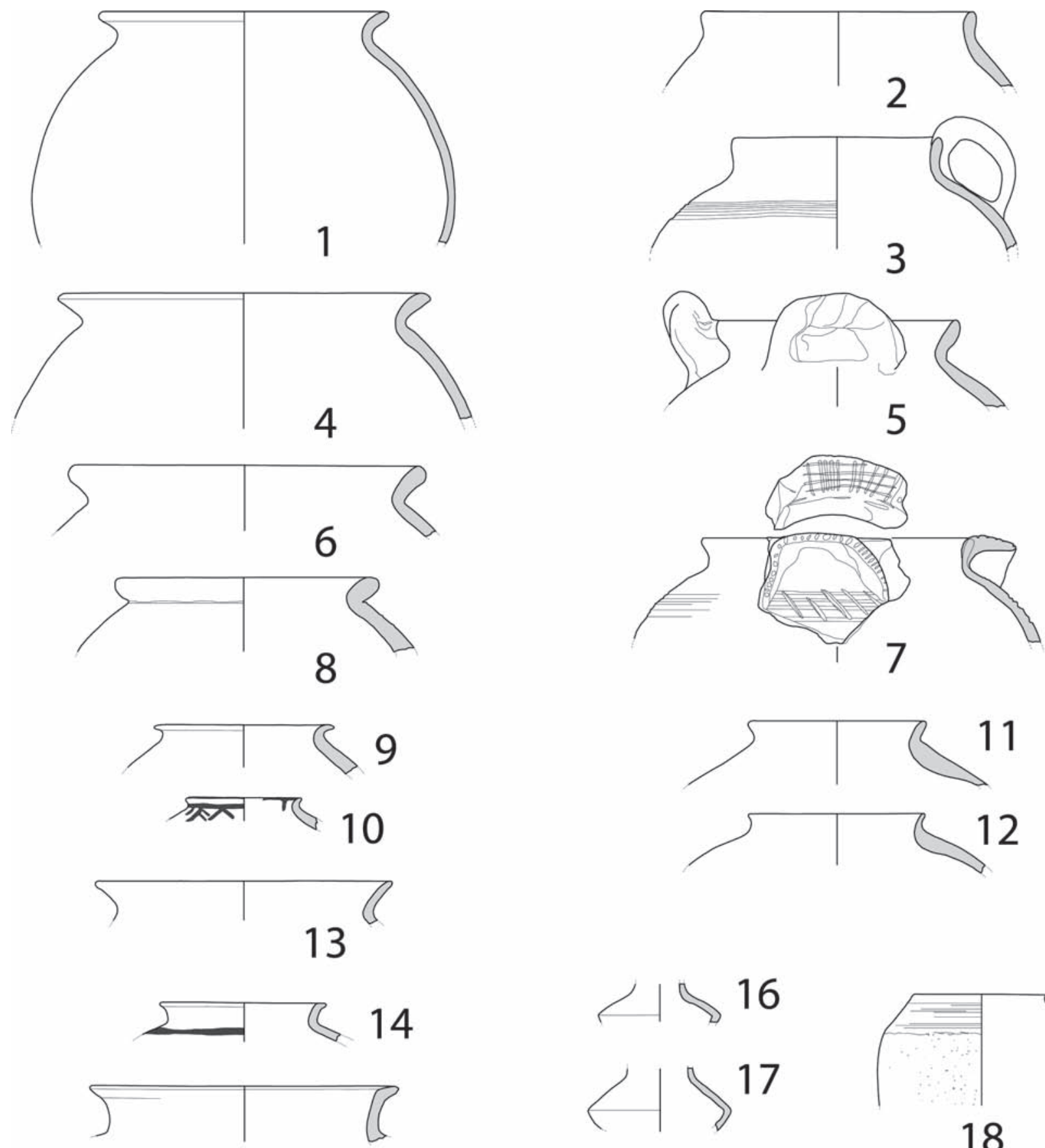

15

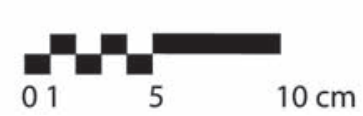


TABLE 3. Mouth diameter values for globular jars with short rounded rim.

\begin{tabular}{|c|c|}
\hline Mouth diam. & Quantity \\
\hline $10 \mathrm{~cm}$ & 1 \\
\hline $11 \mathrm{~cm}$ & 1 \\
\hline $13 \mathrm{~cm}$ & 1 \\
\hline $14 \mathrm{~cm}$ & 2 \\
\hline $15 \mathrm{~cm}$ & 3 \\
\hline $16 \mathrm{~cm}$ & 2 \\
\hline $18 \mathrm{~cm}$ & 4 \\
\hline $19 \mathrm{~cm}$ & 3 \\
\hline $20 \mathrm{~cm}$ & 1 \\
\hline $21 \mathrm{~cm}$ & 3 \\
\hline $22 \mathrm{~cm}$ & 7 \\
\hline $24 \mathrm{~cm}$ & 2 \\
\hline $25 \mathrm{~cm}$ & 1 \\
\hline $26 \mathrm{~cm}$ & 2 \\
\hline $35 \mathrm{~cm}$ & 1 \\
\hline
\end{tabular}

Fig. 17. (on left) Globular and subglobular vessels. 1. Trench V, TV-9. Semi-fine ware with mica, light grey (10 YR 7/2). Mouth diam. $17 \mathrm{~cm}$. 2. Lot 16/207. Semi-fine ware, very pale brown (10 YR 8/3), mouth diam. $16 \mathrm{~cm}$. 3. Trench $V$, $T V$-9. Semi-fine ware with a sandy temper, very pale brown (10 YR 8/3). Mouth diam. $12 \mathrm{~cm}$. 4. Lot 22. Semi-fine ware, very pale brown (10 YR 8/3). Mouth diam. $16 \mathrm{~cm}$. 5. Lot 22. Semi-coarse ware with a sandy temper, light grey (10 YR 7/2). Mouth diam. $11 \mathrm{~cm}$. 6. Lot 16/222. Semi-coarse ware, pinkish grey (7.5 YR 7/2), mouth diam. $20 \mathrm{~cm}$. 7. Trench V, TV-9. Semi-coarse ware with a sandy temper, light grey (10 YR 7/2). Mouth diam. $16 \mathrm{~cm}$. 8. Lot 22/271. Fine ware, tempered with fine sand, pink (10 YR 7/3). Mouth diam. 16 cm. 9. Lot 16/147. Semi-fine ware, including a fine sand component, very pale brown (10 YR 8/3). Mouth diam. 10 cm. 10. Lot 16/148. Semi-coarse ware with mica, pink (7.5 YR 8/4), painted dark brown (7.5 YR 4/2). Mouth diam. 7 cm. 11. Lot 16/145. Semi-fine ware with sand, pink (7.5 YR 7/4). Mouth diam. $11 \mathrm{~cm}$. 12. Lot 16/146. Semi-coarse ware with a sandy temper, very pale brown (10 YR 8/3). Mouth diam. $10 \mathrm{~cm}$. 13. Lot 16/144. Semi-coarse ware with a sandy temper, light grey (10 YR 7/2). Mouth diam. $17 \mathrm{~cm}$. 14. Lot 21/294. Semi-fine ware with sand, pale brown (10 YR 6/3), painted dark greyish brown (10 YR 4/2). Mouth diam. 10 cm. 15. Lot 16/223. Semi-fine ware with sand, pinkish grey (7.5 YR 7/2). Mouth diam. $18 \mathrm{~cm}$. 16. Lot 22/315. Fine grey burnished ware, light grey (10 YR 6/1). 17. Lot 21/267. Semi-fine ware, yellow (10 YR 7/6). 18. Lot 19/206. Semicoarse ware, sand tempered, light grey (10 YR 7/2). Mouth diam. $8 \mathrm{~cm}$. (Image M. Vidale and F. Desset.)
TABLE 4. Size of oval trays (based on reconstructed base diameters).

$\begin{array}{cc}\text { Diam. at base (2 cm interval) } & \text { Quantity } \\ 20-21 \mathrm{~cm} & 1 \\ 22-23 \mathrm{~cm} & 1 \\ 24-25 \mathrm{~cm} & 1 \\ 26-27 \mathrm{~cm} & 7 \\ 28-29 \mathrm{~cm} & 4 \\ 30-31 \mathrm{~cm} & 3 \\ 32-33 \mathrm{~cm} & 8 \\ 34-35 \mathrm{~cm} & 4 \\ 36-37 & 1 \\ 38-39 & 1 \\ 40-41 & 1 \\ 42-43 & 2 \\ 44-45 & - \\ 46-47 & - \\ 48-49 & 2 \\ 50-51 & - \\ 52-53 & - \\ 54-55 & 1\end{array}$

man. ${ }^{47}$ Its lower body was extensively trimmed with vertical movements.

Coarse, heavily chaff-tempered oval trays with a low side (Fig. 18.1-2 and Fig. 19) are another recurrent type of this chronological and cultural horizon. The trays at Mahtoutabad have a short sub-vertical and inward-inflected wall ending in a rounded rim. There are also trays with outward-inflected walls, which in general are higher than the former ones. The second form was in use at Chogha Mish, but is better documented at Tepe Farukhabad, Tepe Yahya and Tal-e Malyan, ${ }^{48}$ as well as at Tol-e Spid. ${ }^{49}$ Both types, however, were used at Chogha Mish, Tal-e Malyan, Godin Tepe, Tal-i Iblis, Tepe Sofalin and Arisman. ${ }^{50}$ At Arisman a drop-shaped tray, evidently conceived for pouring from the restricted side, 51 has the same technical implications of the spouted rim of the Mahtoutabad

47 Helwing 2011a: 237, fig. 25.121.

48 Delougaz and Kantor 1996: fig. 86, DD-GG; Wright 1981: fig. 42, a; Potts D.T. 2001: figs. 1.22.E, 2.19.E, 3.14.O; Sumner 2003: fig. 23, b-e.

49 Petrie et al. 2009a: figs. 4.62 and 4.6, 4.73, TS 1302 and TS 1691; 4.77, TS 1182.

50 Delougaz and Kantor 1996: fig. 86, N-BB; Sumner 2003: fig. 23, a; Rothman and Badler 2011: figs. 4.52-4.53; Caldwell 1967: fig. 24 (bottom); Hesari 2011: fig. 7; Helwing 2011a: 247, fig. 35.189 .

51 Helwing 2011a: 246, fig. 34; see also p. 245, fig. 33.186. 

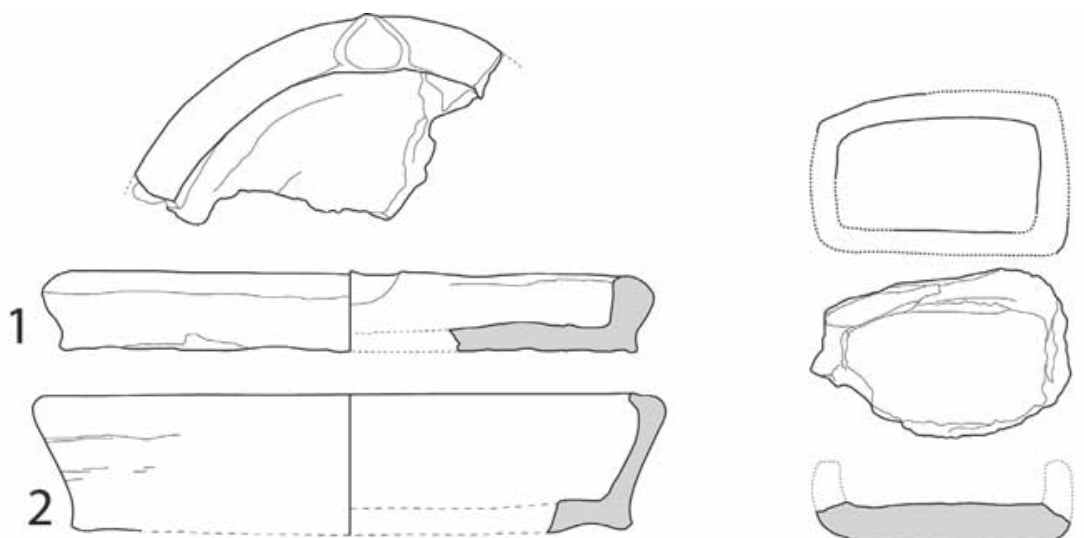

3
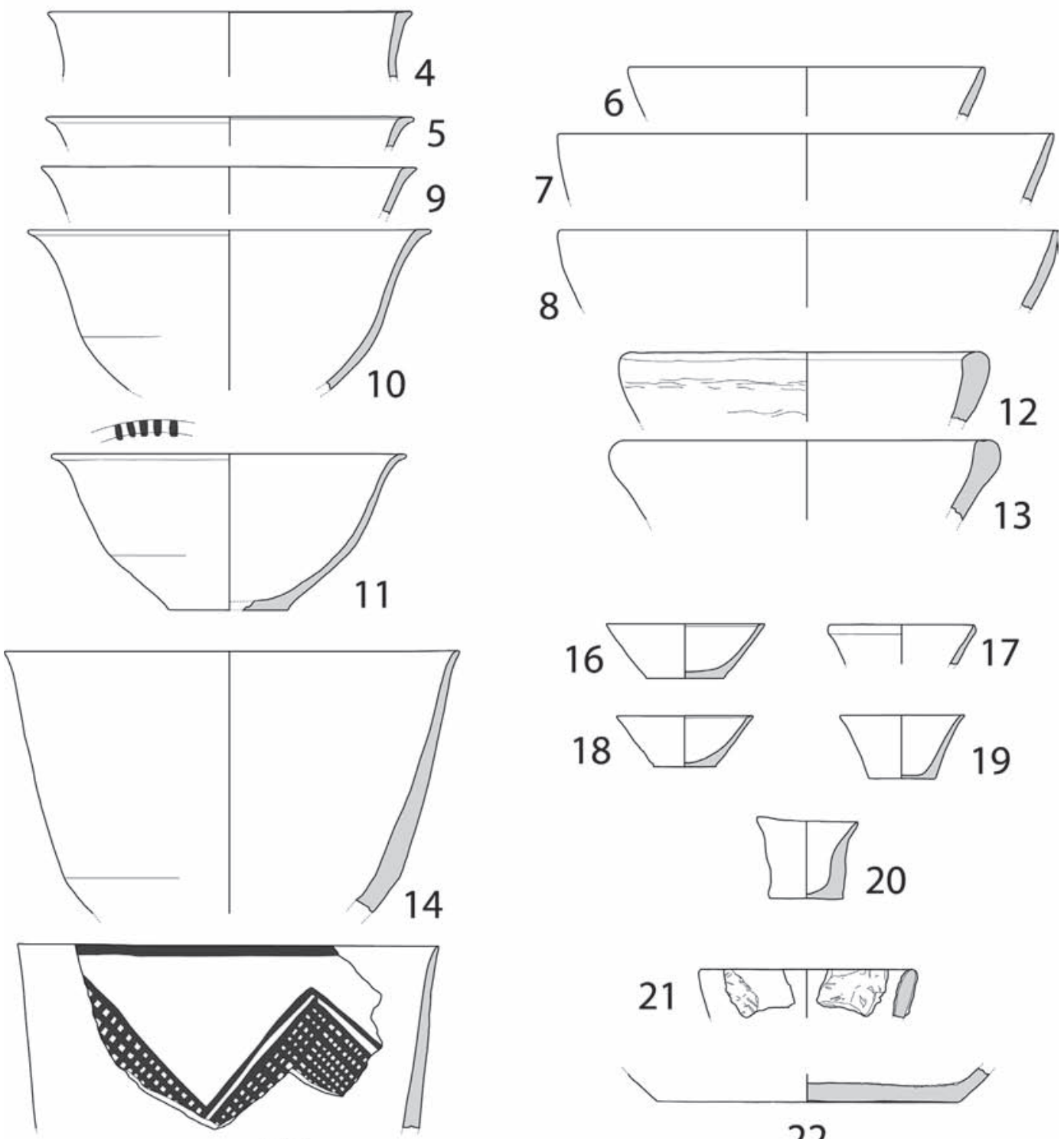

15
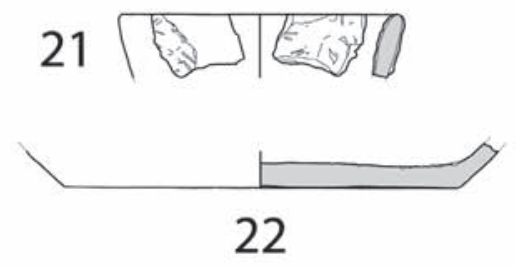
Fig. 18. (On left) Trays and unrestricted bowls. 1. Lot 22. Coarse ware, chaff-tempered, very pale brown (10 YR 7/4). 2. Lot 22. Coarse ware, heavily chaff-tempered, light grey (2.5 Y 7/2). 3. Lot 22/320. Coarse ware, chaff-tempered, pale brown (10 YR 6/3); c. 11 x $6.5 \mathrm{~cm}$. 4. Lot 19/204. Semi-coarse ware with fine micaceous sand, very pale brown (10 YR 7/4). Mouth diam. 20 cm. 5. Lot 19/205. Fine ware, very pale brown (10 YR 7/3). Mouth diam. 20 cm. 6. Lot 19/164. Semi-fine ware with sand, white (10 YR 8/2). Mouth diam. $28 \mathrm{~cm}$. 7. Lot 19/165. Semi-fine ware with mica, pink (7.5 YR 7/4). Mouth diam. $28 \mathrm{~cm}$. 8. Lot 19/166. Semi-fine sand-tempered ware, white (10 YR 8/2), with traces of greyish brown (10 YR 5/2) painted designs. Mouth diam. $20 \mathrm{~cm}$. 9. Lot 16/212. Semi-fine ware with mica, white (10 YR 8/2). Mouth diam. 20 cm. 10. Lot 21/329. Semi-fine ware with fine sand, mica, very pale brown (10 YR 7/3). Mouth diam. $22 \mathrm{~cm}$. 11. Lot 22/284. Semi-fine ware with mica, pinkish grey (7.5 YR 7/2), painted on the rim in dark brown (7.5 YR 4/2). Mouth diam. $20 \mathrm{~cm}$, base diam. $7 \mathrm{~cm}$. 12. Lot 16/210. Coarse chaff-tempered ware, pale brown (10 YR 6/3). Mouth diam. $19 \mathrm{~cm}$. 13. Lot 16/211. Coarse chaff-tempered ware, pale brown (10 YR 6/3). Mouth diam. $20 \mathrm{~cm}$. 14. Lot 22/273. Semi-fine ware with sand and mica, very pale brown (10 YR 7/4). Mouth diam. $26 \mathrm{~cm}$. 15. Lot 22/316. Semi-fine ware with mica, light grey (10 YR 7/2), painted dark grey (10 YR 4/1). Mouth diam. $24 \mathrm{~cm}$. 16. Lot 22/285. Fine ware, white (10 YR 8/2). Mouth diam. $8.5 \mathrm{~cm}$, base diam. $4 \mathrm{~cm}$. 17. Lot 16/218. Semi-fine ware with mica, pink (7.5 YR 7/4). Mouth diam. $8 \mathrm{~cm}$, base diam. $3.5 \mathrm{~cm}$. 18. Lot 21/265. Fine ware with mica, light grey (10 YR 7/2). Mouth diam. $8 \mathrm{~cm}$, base diam. $3.5 \mathrm{~cm}$. 19. Lot 21/264. Fine ware with mica, light yellowish brown (10 YR 6/4). Mouth diam. $7 \mathrm{~cm}$, base diam. $4 \mathrm{~cm}$. 20. Lot 21/263. Semi-fine ware, pale brown (10 YR 6/3). Mouth diam. $6 \mathrm{~cm}$, base diam. $4.5 \mathrm{~cm}$. 21. Lot 16/213. Coarse chaff-tempered ware, pale brown (10 YR 6/3), coated inside and on the exterior surface with a film of heavily chaff-tempered clay. Mouth diam. $12 \mathrm{~cm}$. 22. Lot 19/167. Coarse, sandtempered ware, reddish yellow (7.5 YR 6/6). The inner bottom is covered with a grit-like surface. Base diam. $21 \mathrm{~cm}$. (Image M. Vidale and F. Desset.)

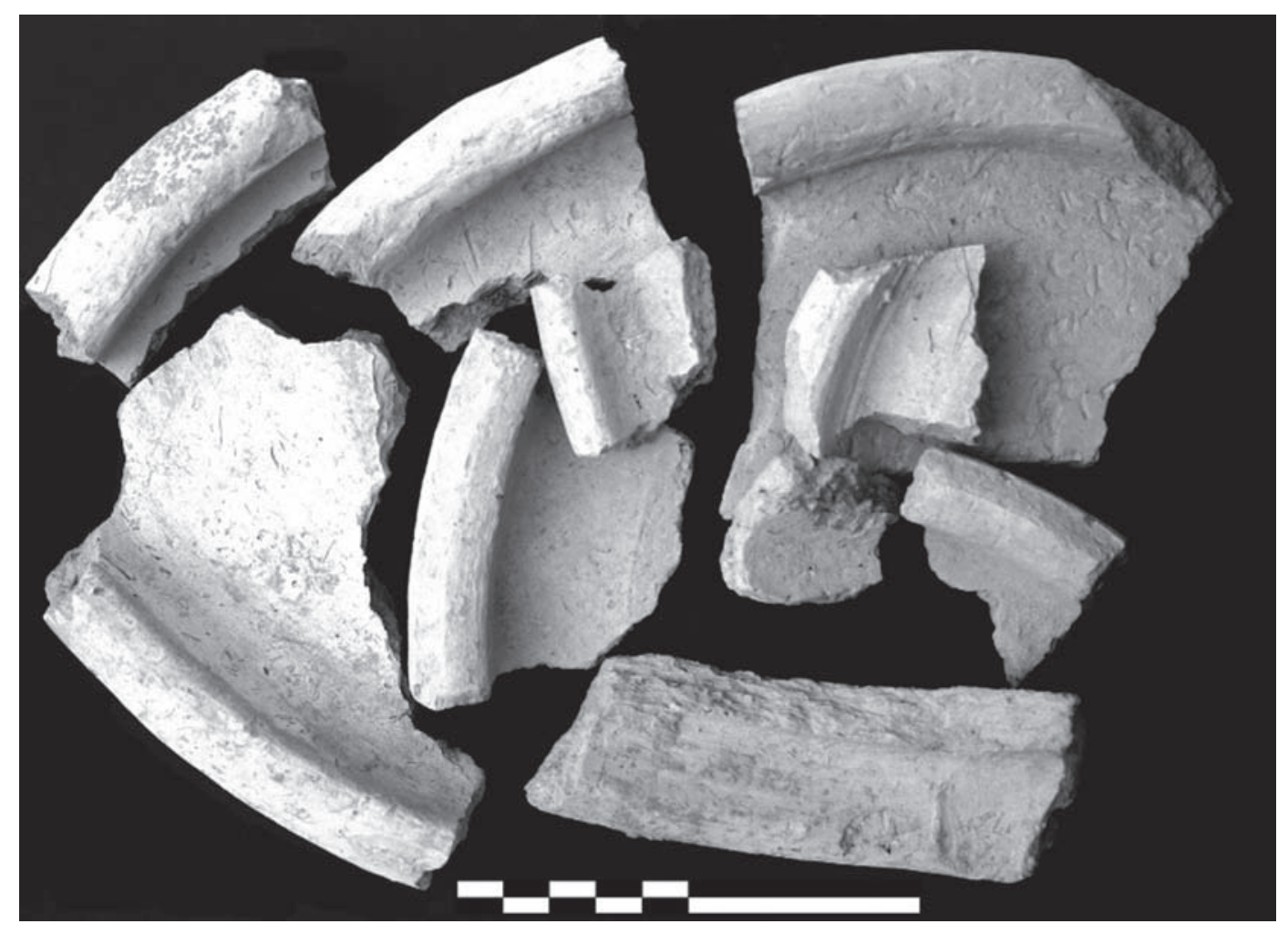

Fig. 19. Mahtoutabad: fragments of low-sided coarse chaff-tempered trays. (Image M. Vidale.) 
one, while an oval tray found at Tal-e Malyan 52 is almost identical to our specimens.

These trays are generally broken into small fragments and determining the original diameters is often difficult. Due to the inward-inflected rim, measures are better taken on the base than on the rim. The variations of the mouth diameter of oval trays (from excavated area and surface lots) appear in Table 4.

The two clusters (respectively c. 26-27 and 32-35 $\mathrm{cm})$ are due to the oval shape of the vessels, suggesting an average length of $c .38 / 40 \times 28 \mathrm{~cm}$. The measurements, however, also show the presence of a certain number of specimens of much larger size.

The low-sided rectangular tray or box shown in Figure 18.3 is very coarse and in spite of its superficial resemblance to some of the crucibles from Tal-i Iblis, ${ }^{53}$ may have been a small mould for a flat copper object. Similar objects were also found at Arisman and on the surface of Banesh sites in the Kur River Basin. ${ }^{54}$

While the fragments shown in Figure 18.6-8 demonstrate that our assemblage includes thin-walled hemispherical bowls of variable size, the finely fashioned bowls in Figure 18.4-5 and 9-11 are another recurrent type. They were made with a fine clay in a relatively standardised size, around $20-22 \mathrm{~cm}$. The body is hemispherical, with a slightly S-shaped overall contour, and the lower inflection point being the limit of the lower turned area. The projecting rim has a distinctive upper flat tangency, and sometimes rows of short lines and dots, incised or painted. Such bowls were probably made on the potter's wheel using a coilbuilding process.

Variants of the same type were found at Tol-e Nurabad,55 Tol-e Spid,56 Chogha Mish,57 Arisman Area C ("Proto-Elamite") 58 and Tal-i Iblis..$^{59}$ Although the type is obviously the same, in each region the model was re-interpreted and recreated. The Mahtoutabad III

52 Sumner 2003: fig. 23, a; see also Delougaz and Kantor 1996: pl. 86, P.

53 Caldwell 1968b: fig. 6.

54 Helwing 2011b: 316 and 317, figs. 89 and 90; Alden 2003b: D8, 15.

55 Weeks et al. 2009: fig. 3.112, TNP257.

56 Petrie et al. 2009a: fig. 4.65, TS 1858, and fig. 4.67, TS 1467.

57 Delougaz and Kantor 1996: pls. 84.Y and Z, and 85.B and C.

58 Helwing 2011a: fig. 38.245, 246 and 248; see also fig. 37.235-237 and 241; compare with the decoration on the rim of the globular pots in fig. 23.97-98.

59 Caldwell 1967: fig. 39 (upper). specimens are fine products, and are better compared with similar vessels at Arisman Area B, 60 linked by the means of ceramic comparisons to Sialk III (c. 3500 $\mathrm{BC})$, rather than with Arisman C contexts. The possibility that some materials in the Mahtoutabad III assemblage correspond to these horizons is enhanced by the comparanda for Figure 18.14 - an open bowl with a slightly S-shaped profile, weak carination and pointed rim -with Figure 18.15 as a possible painted variant. ${ }^{61}$ Together with this type, the small bowls with a club-like rim (Fig. 11.12-13) and the miniature truncated-cone-shaped bowls (Fig. 18. 16-19) are also very similar to specimens from Arisman area B. ${ }^{62}$ The thick-walled conical bowl (Fig. 18.21) is coated with a thin layer of chaff-tempered slip, both inside and outside; it is a unicum and might have been used in a specific yet unknown activity.

\section{III.2. "Local" painted pottery types}

Painted light buff wares (Fig. 18.15 and Figs 20, 21, 22 and 23 ) amount to no more that $2-3 \%$ of the total, and may be local and/or regional types. Their inventory includes some types not represented in our figures, such as fragments of large globular jars painted with broad black and red horizontal bands, truncatedcone-shaped bowls with wide intersecting festoons hanging from the inner rim, and a small pot or jar with bichrome (black and red) geometric patterns. The bulk of the painted wares at Mahtoutabad III, however, are fine, small restricted jars or carinated pots bearing simple dark grey painted geometric friezes (Fig. 21.2-10). Bases of small- and medium-sized buff ware jars (Fig. 21.12-17) might belong to the same class of containers.

The local painted types (Fig. 24) match pots found in other sites, such as Tal-i Iblis, and might well be part of the same regional tradition. While the technical quality of these small- to medium-sized vessels is often excellent, particularly for the smaller bowls (fine paste, thin walls clinky to the touch, smooth surface, uniform firing conditions), the designs are limited to

60 Parzinger 2011: figs. 48.422-425 and 428; 50.440 and 442; 53.489 and 490.

61 Parzinger 2011: figs. 42.341; 45.381-383; 48.422 and 425; 52.477 and 479. The type is also reported at Godin Tepe; Badler 2002: figs. 7. N3 30; 11. A2 1187 nos. 34 and 32; 13. B1 1479 no. 147; Rothman and Badler 2011: fig. 4.44.

62 See, respectively, Parzinger 2011: figs. 50.438 and 51.453. 

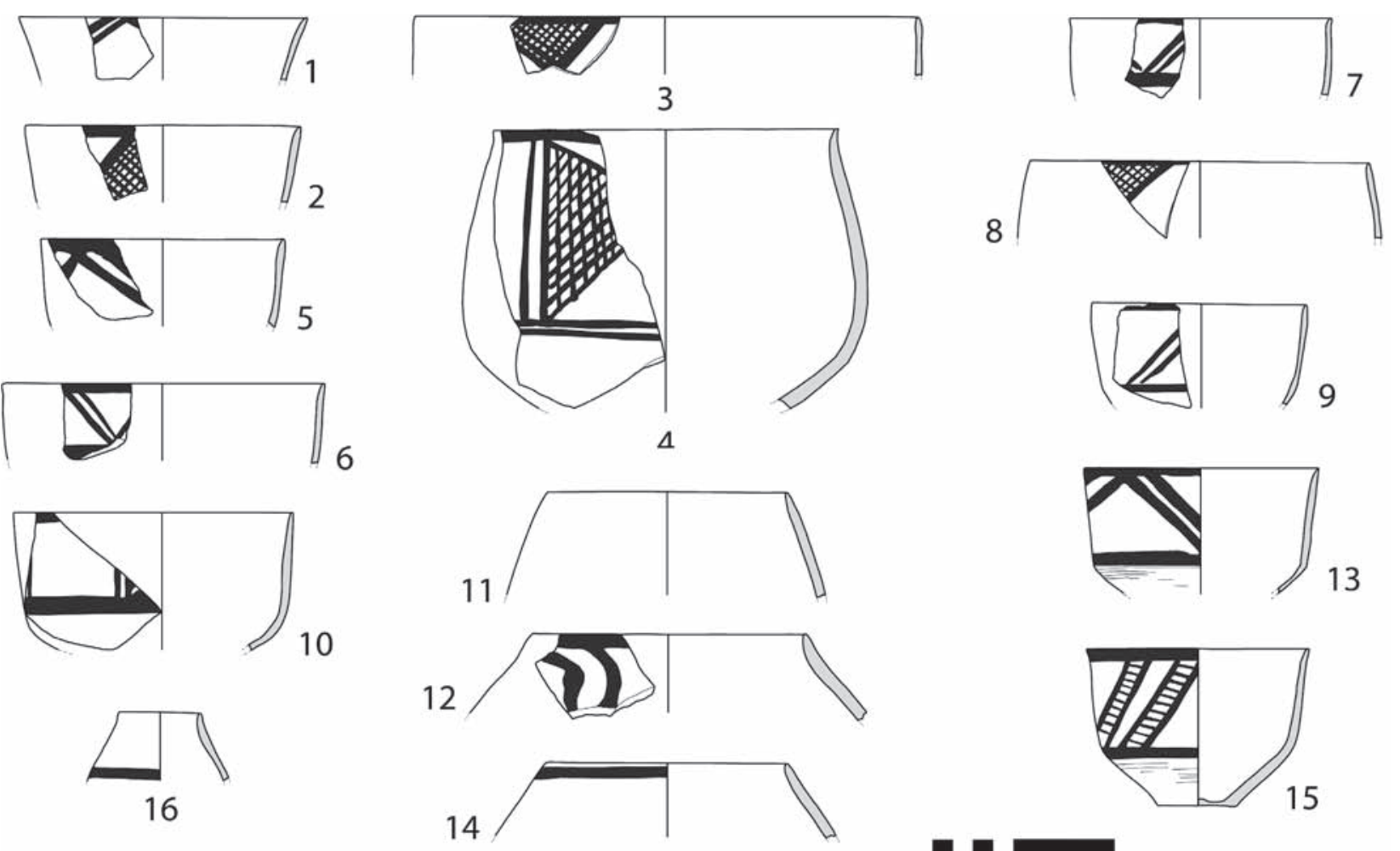

Fig. 20. (On right) Small restricted bowls. 1. Lot 16/221. Fine ware, very pale brown (10 YR 8/3) painted pale brown (10 YR 6/3). Mouth diam. $14 \mathrm{~cm}$. 2. Lot 22/317. Fine ware, light grey (10 YR 7/2) painted dark grey (10 YR 4/1). Mouth diam. $13 \mathrm{~cm}$. 3. Lot 16/143. Fine ware, white (10 YR 8/2) painted black (10 YR 8/1). Mouth diam. $24 \mathrm{~cm}$. 4. Lot 22/347. Fine ware, light grey (10 YR 7/2) painted dark grey (10 YR 4/1). Mouth diam. $13 \mathrm{~cm}$. 5. Lot 16/131. Fine ware, very pale brown (10 YR 8/3) painted pale brown (10 YR 6/3). Mouth diam. $12 \mathrm{~cm}$. 6. Lot 22/347. Semi-fine ware, pink (7.5 YR 7/4) painted grey (7.5 YR 5/0). Mouth diam. $18 \mathrm{~cm}$. 7. Lot 16/131. Semi-fine ware, white (10 YR 8/2) painted weak red (10 R 4/2). Mouth diam. $16 \mathrm{~cm}$. 8. Lot 22/302. Semi-fine ware, light grey (10 YR 7/2) painted dark brown (10 YR 4/1). Mouth diam. $17 \mathrm{~cm}$. 9. Lot 16/261. Fine ware, very pale brown (10 YR 8/3) painted dark reddish grey (10 R 4/1). Mouth diam. $13 \mathrm{~cm}$. 10 . Lot 21/261. Fine ware with mica, pale brown (10 YR 6/3) painted dark greyish brown (10 YR 4/2). Mouth diam. $11 \mathrm{~cm} .11$.

Lot 22/301. Semi-fine ware with mica, pink (7.5 YR 7/4). Mouth diam. $12 \mathrm{~cm}$. 12. Lot 21/293. Semi-fine ware, light brown (7.5 YR 6/4) painted dark grey (7.5 YR 4/0). Mouth diam. $14 \mathrm{~cm}$. 13. Lot 22/259. Fine ware, very pale brown (10 YR 7/3), painted dark grey (10 Yr 4/0). Mouth diam. $1 \mathrm{~cm}$. 14. Lot 22/303. Semi-fine ware, light grey (10 YR 7/2) painted dark grey (10 YR 4/1). Mouth diam. $13 \mathrm{~cm}$. 15. Trench V, TV-9. Semi-fine ware, sand-tempered, light grey (2.5 Y7/2) painted very dark grey (2.5 Y 3/0). Mouth diam. $11 \mathrm{~cm}$. 16. Lot 21/260. Semi-fine ware with chaff and mica, very pale brown (10 YR 8/3) painted dark greyish brown (10 YR 4/2). Mouth diam. $11 \mathrm{~cm}$. (Image M. Vidale and F. Desset.) 

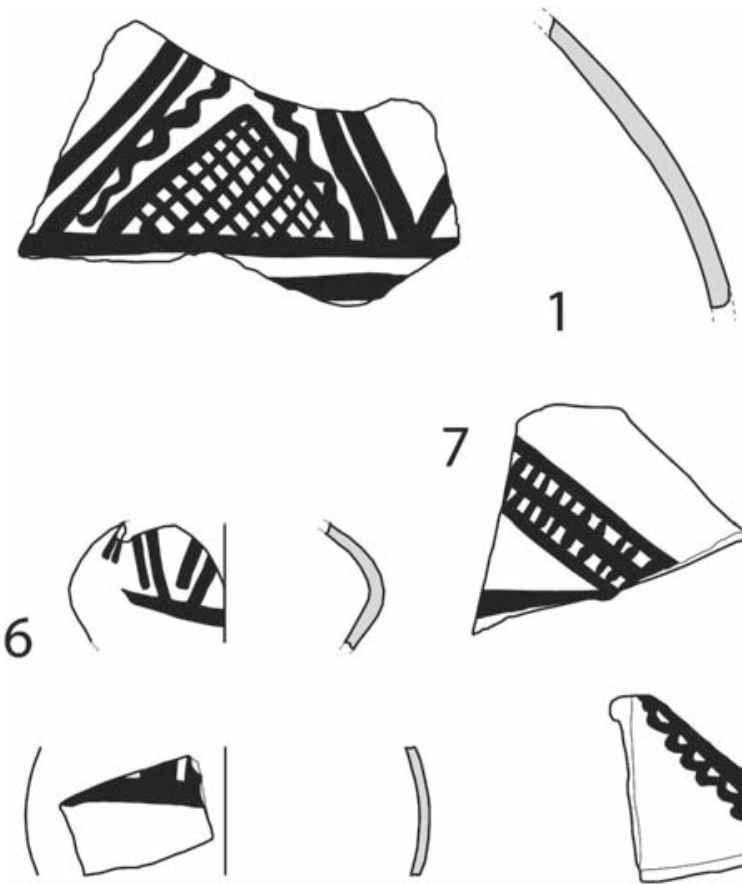

10

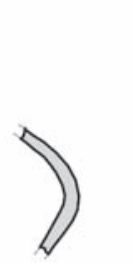

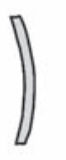

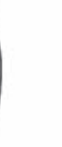

11
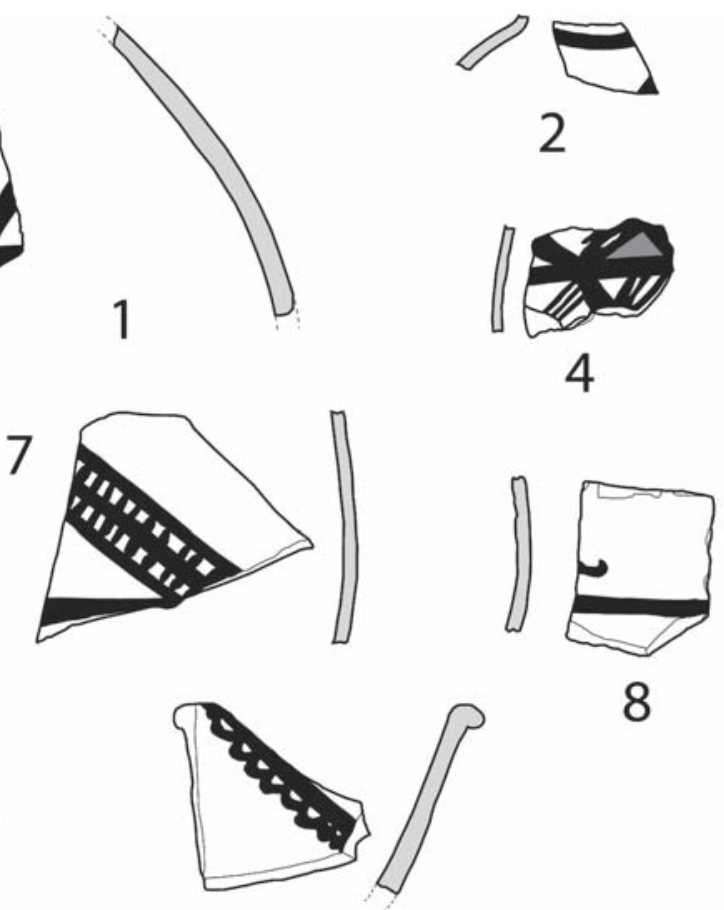

8
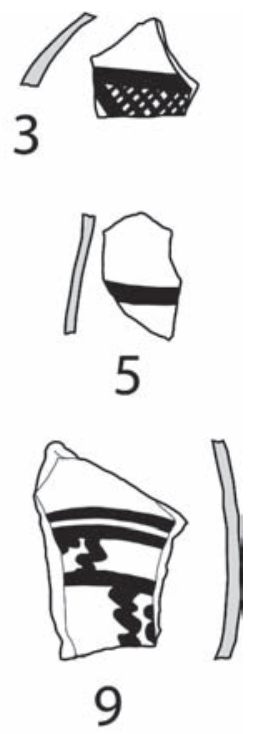

Fig. 21. Painted walls and undeterminable bases. 1. Lot 21. Fine ware, very pale brown (10 YR 7/3) painted pale brown (10 YR 6/3). 2. Lot 16/126. Semi-fine ware, white (10 YR 8/2) painted dark greyish brown (10 YR 4/2). 3. Lot 16/128. Semifine ware with mica, white (10 YR 8/2) painted brown (10 YR 5/3). 4. Lot 16/125. Semi-fine ware with sand, weak red (10 R 5/3). Bichrome decoration, the pattern is painted light grey (10 $Y R 7 / 1)$ and filled with pale red $(10 R 6 / 6) .5$. Lot 16/127. Semi-fine ware with mica, white (10 YR 8/2) painted grey (10 YR 6/1). 6. Lot 21/266. Fine ware with mica, very pale brown (10 YR 7/3) painted light brownish grey (10 YR 6/1). 7. Lot 22/318. Semi-fine ware with fine sand, white (10 YR 8/2) painted greyish brown (10 YR 5/2). 8 . Lot 16/129. Semi-fine ware, very pale brown (10 YR 7/3) painted grey (10 YR 6/1). 9. Lot 16. Fine ware, white (10 YR 8/2) painted dark brown (10 $Y R$ 4/3). 10. Lot 16/124. Fine ware with mica, white (10 YR 8/2) painted black (10 YR 8/1). 11. Lot 21/292. Semi-fine ware with sand, pale red
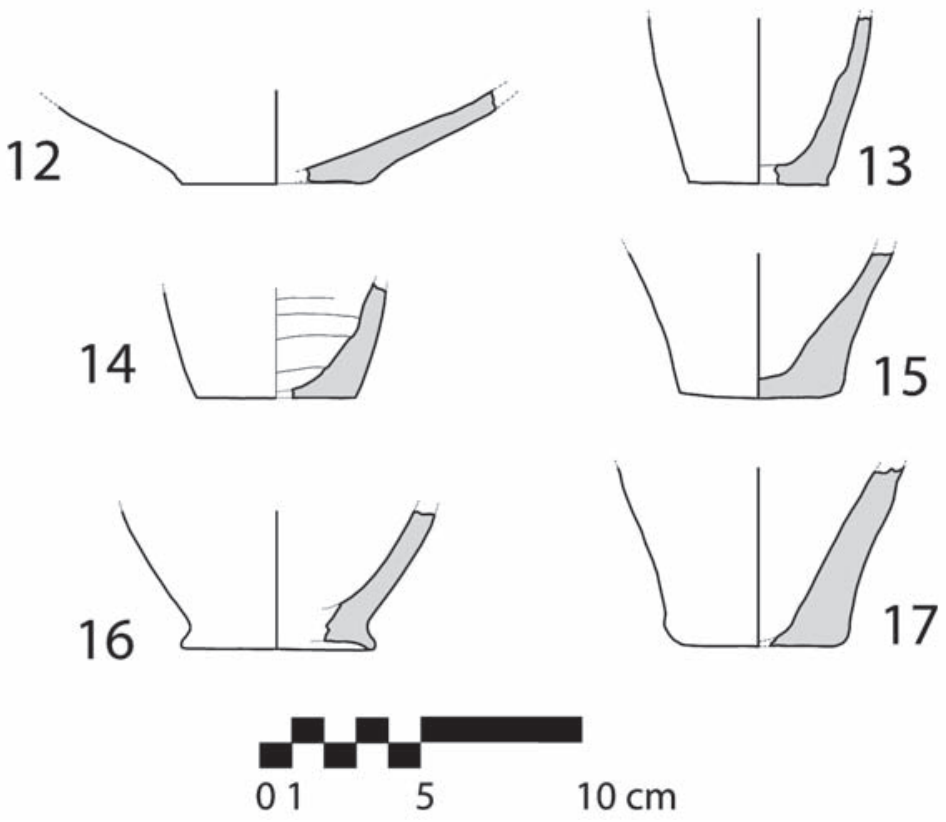
(10 R[YR?] 6/4) painted weak red (10 R[YR?]

4/2). 12. Lot 16/209. Semi-coarse ware with mica, light grey (10 YR 7/2). Base diam. 6 cm. 13. Lot 16/149. Semi-fine ware with sand, light red (10 R[YR?] 6/6). Base diam. $4.5 \mathrm{~cm}$. 14. Lot 16/214. Semi-fine ware, very pale brown (10 YR 7/3). Base diam. $5 \mathrm{~cm}$. 15. Lot 16/150. Semi-fine chaff tempered ware, reddish yellow (7.5 YR 7/4). Base diam. $5 \mathrm{~cm} .16$. Lot 16/215. Semi-coarse ware with mica, white (10 YR 8/2). Base diam. $6 \mathrm{~cm}$. 17. Lot 16/151. Medium ware, white (10 YR 8/2). Base diam. $6 \mathrm{~cm}$. (Image M. Vidale and F. Desset.) 


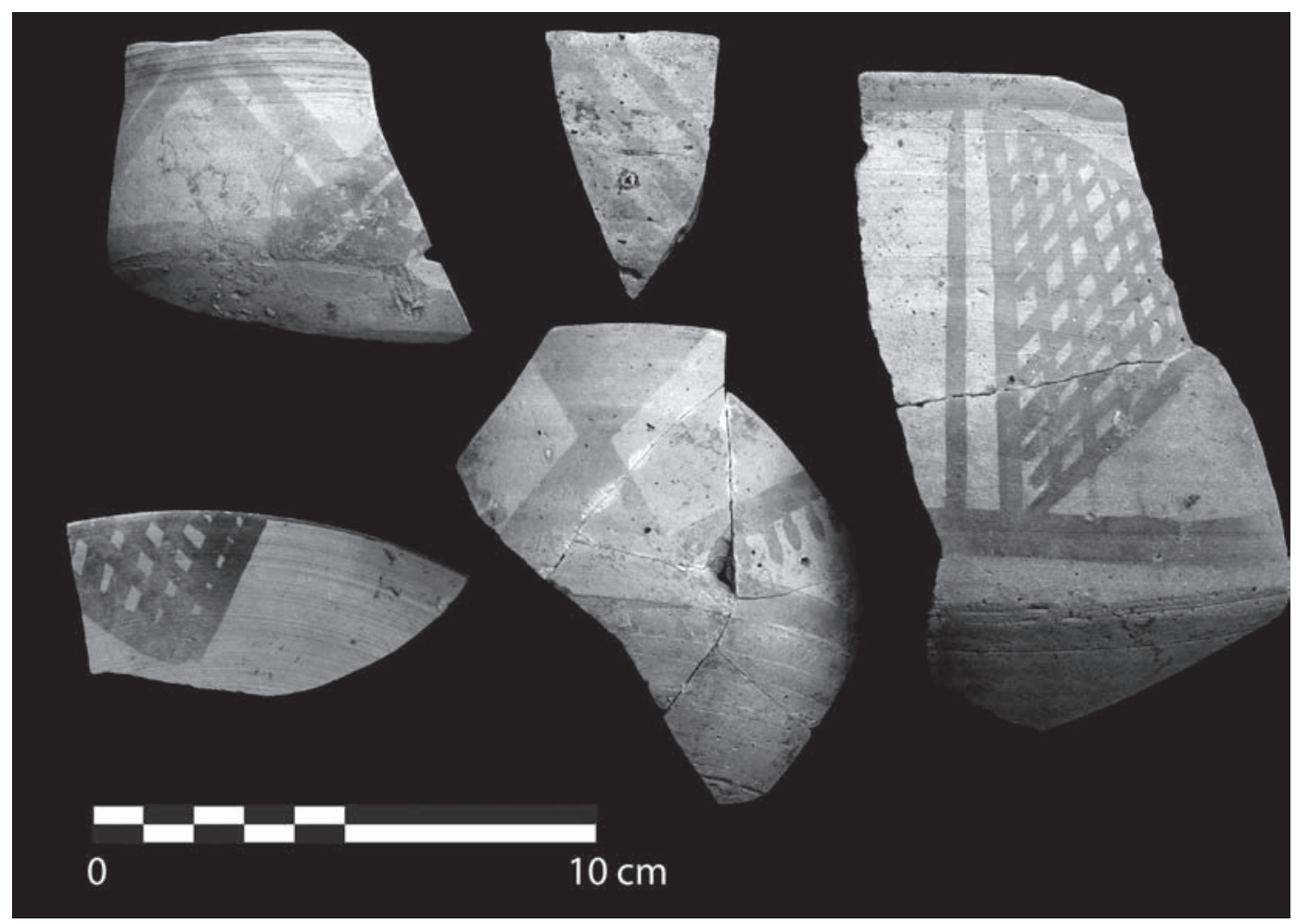

Fig. 22. Mahtoutabad: samples of fine painted vessel fragments. (Image M. Vidale.)

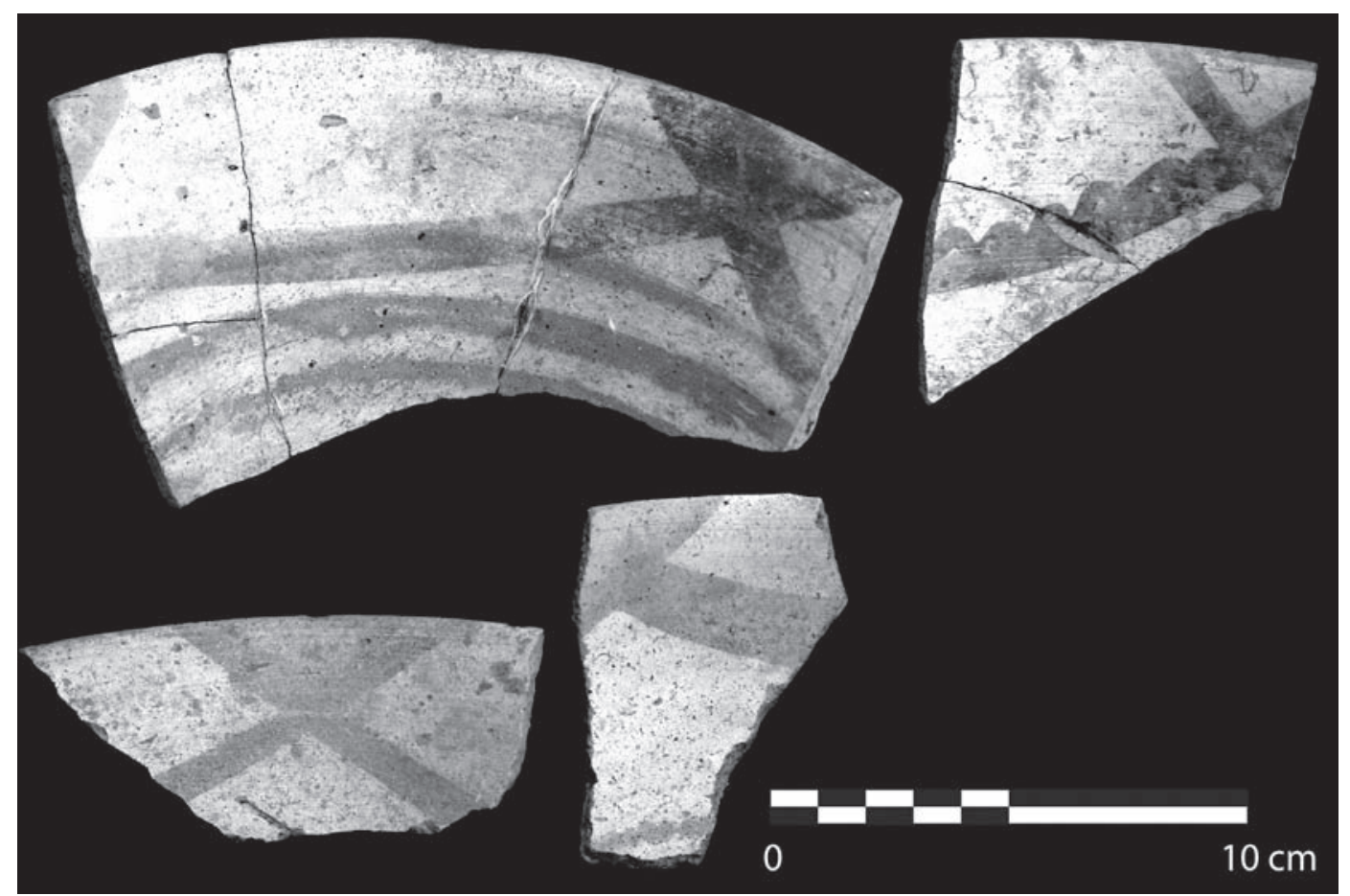

Fig. 23. Mahtoutabad: fragments of truncated-cone-shaped bowls, decorated with wide loops hanging from the inner rim. The red horizontal bands in the uppermost fragment are due to the friction and abrasion with other identical vessels piled one inside the other. (Image M. Vidale.) 
Tal-i Malyan

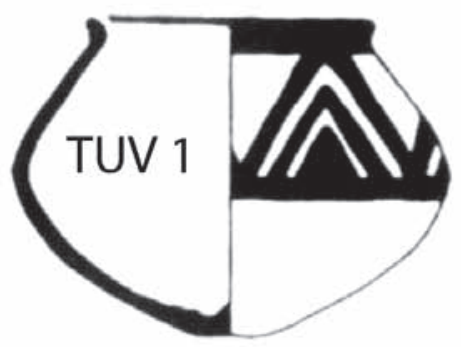

maroon on beige slip

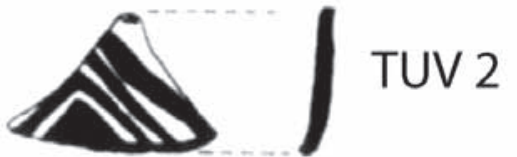

red on light orange

Nicholas 1990, pl. 17.a et 24.a

Tal-i Iblis
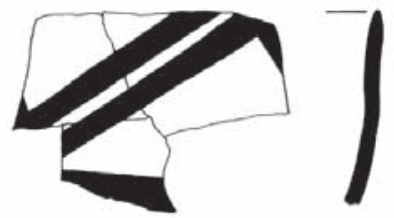

no context

Caldwell et al. 1967, fig.45.1

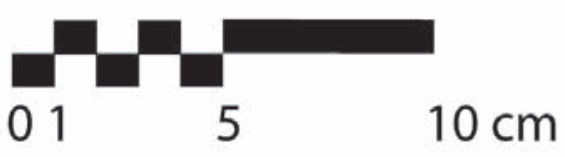

Tepe Yahya
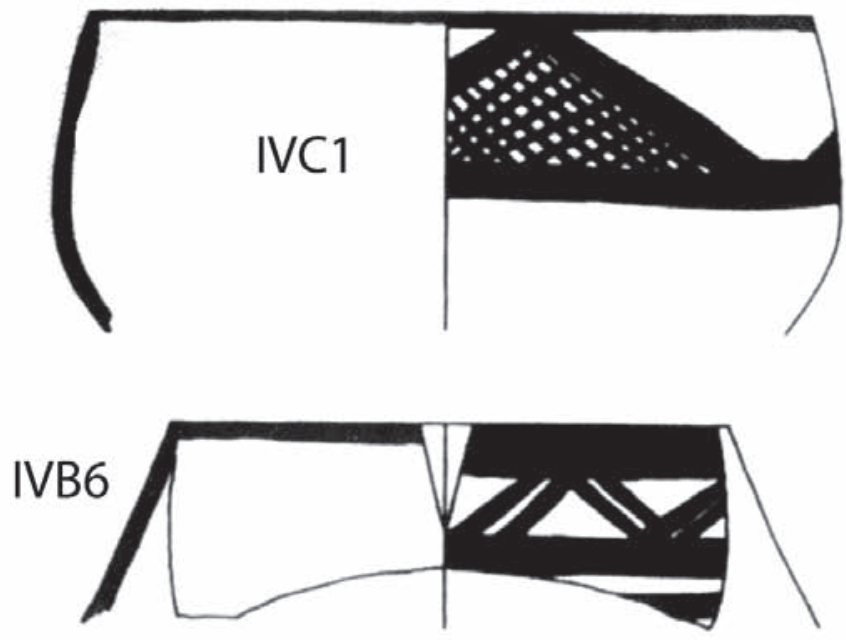

black on grey ware

Potts 2001, fig. 1.12

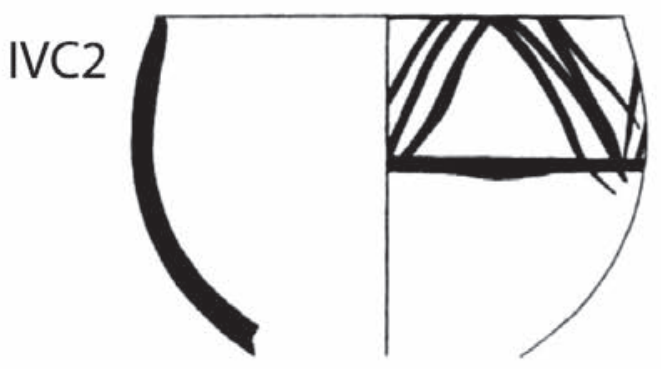

Potts 2001, fig. 1.44.C

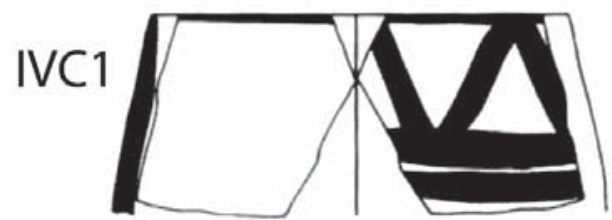

Potts 2001, fig. 2.25.C

black on buff ware

Fig. 24. Ceramic comparisons. (Image F. Desset.) 
TABLE 5. Classification and statistics of Mahtoutabad III ceramics in lot nos. 16-21 (materials found in the fillings of two looting pits, later included in Trench V).

\begin{tabular}{|l|l|c|c|}
\hline Type or item & Description/part of vessel & Quantity & \% \\
\hline low-sided tray & rim fragments & 25 & 2.47 \\
\hline low-sided tray & base fragments & 16 & 1.58 \\
\hline bevel-rim bowl & rim fragments & 47 & 4.64 \\
\hline bevel-rim bowl & wall fragments & 29 & 2.89 \\
\hline bevel-rim bowl & base fragments & 64 & 6.35 \\
\hline truncated-cone bowl & rim + wall fragments & 22 & 2.17 \\
\hline bowl with pointed rim & rim fragments & 19 & 1.87 \\
\hline flowerpot & base fragments & 14 & 1.38 \\
\hline flowerpot & wall fragments & 12 & 1.18 \\
\hline vase with round bottom & bases & 4 & 0.39 \\
\hline vase with round bottom & wall fragments & 25 & 2.49 \\
\hline vase with rim spout & rim fragment + spout & 5 & 0.49 \\
\hline shoulder spout & wall fragments + spout & 12 & 1.18 \\
\hline globular jar, grooved & (rim, shoulder, handle) & 25 & 2.47 \\
\hline medium-large jar & rims + shoulder & 21 & 2.07 \\
\hline medium-large jar & plain wall fragments & 211 & 20.89 \\
\hline medium-large jar & base fragments & 7 & 0.69 \\
\hline medium-large jar & wall fragments, painted & 15 & 1.48 \\
\hline nose-lug jar & shoulder fragment & 1 & 0.09 \\
\hline carinated jar & shoulder fragments & 4 & 0.39 \\
\hline small jar, flat rim & rim fragments & 15 & 1.48 \\
\hline small jar & shoulder fragments & 6 & 0.59 \\
\hline small jar or bowl & wall fragments & 358 & 35.43 \\
\hline small jar or bowl & flat base fragments & 27 & 2.67 \\
\hline small carinated jar & rim or shoulder fragments & 9 & 0.89 \\
\hline miniature vessel & (unpainted) fragments & 15 & 0.29 \\
\hline small jar or bowl, painted* & various fragments & 1.48 \\
\hline Total & & $\mathbf{1 0 1 1}$ & $\mathbf{1 0 0 \%}$ \\
\hline & & & \\
\hline
\end{tabular}

* black on light cream to white, black on buff, black and red on buff

friezes of double zigzag lines, wavy lines and festoons, hatched triangles, hatched bands and butterfly/ hourglass patterns.

\section{III.3. A quantitative estimate}

Table 5 presents the counts of the sherds collected inside two illegally dug pits where the Mahtoutabad III layer was particularly thick and rich in material. These counts are complicated because some types (like BRBs) are immediately recognisable even from small sherds, while others can be identified only through the presence of smaller and less common distinctive elements (e.g. spouts and lugs). Similarly, small base fragments of oval trays can hardly be distinguished from those of other pots, and fine small jars cannot easily be identified from bowls of the same size. The sturdy cylindrical base fragments of flowerpots are very easy to identify, but their thin walls and tiny rim fragments are not, and were probably counted in other groups. Thus, the values of Table 5 are indicative, rather than absolute.

A total number of 1011 sherds were counted in this sample. This selected sample is dominated by restricted vessels, mainly scarcely diagnostic sherds of small-sized containers (small jars and bowls) amounting to $35.43 \%$ of the total, followed by plain fragments of medium-sized jars (20.89\%). More than half of the vessels in this sample, therefore, might have been dedicated to the storage and movement of solids and/ or liquids, especially considering the very limited 
evidence of soot marks that one would have expected if cooking pots were on record. The Mahtoutabad III pottery clearly did not come from a cooking facility. BRBs (rim, wall and base fragments, total $\mathrm{n}=140$ ) account for $13.84 \%$ of the total (approximately the same percentage was independently confirmed by counting the material collected on the surface and in other lots from the Trench V excavation). Oval lowsided trays $(n=41)$ represent $4.05 \%$ of the total. Flowerpots (total $n=26$ ) form $2.56 \%$ of the sample, but this value is most probably underestimated (see above). Painted potsherds $(n=30)$, including both large jars and small finer vessels, represent, as stated above, no more than $2.96 \%$ of the sample. Very large storage jars seem to be absent. It is impossible to say if this reflects the original ceramic assemblage and its functions or if it is a side effect of the local deposition processes.

\section{III.4. Manufacturing technology}

With the obvious exception of BRBs and a few other types, the Mahtoutabad III pottery was fashioned on the potter's wheel, sometimes after a coil-building process. Various medium- or large-sized restricted vessels were made by combining forms of coil building and wheel fashioning.

BRBs were obviously moulded in some kind of container or cavity. The incorrect idea that these vessels were hand-formed by free manipulation (but how exactly? ${ }^{63}$ developed from the observation of fingerprints on the exterior, which were actually left when potters extracted these vessels, still in plastic state, from the mould. One or more thick slabs of chaff-tempered clay, sometimes with seed imprints, were pressed in the bottom of the mould-leaving deep finger or knuckle marks in the inner base-and then lifted up to about one third of the vase's body. 64 Several other slabs were then carelessly applied on top of the initial slabs to build the wall. The last slabs, which were applied to shape the rim, were generally

63 Rothman and Badler 2011: 89.

64 H. Wright (1981: 128) proposed that BRBs at Tepe Farukhabad were made with a single clay lump quickly pressed in a mould/ground cavity, but at Mahtoutabad the thickness reduction in the mid-wall and its frequent twisting when the vessel was lifted rather suggest a slab construction process. For a summary of the various ideas on the construction of BRBs (and their function), see Goulder 2010. thicker than those of the mid-body. As potters pressed the clay insistently at the edge of the inner base, the centre was often much thicker that the inner edge of the base. The interior was smoothed with water or slip, sometimes alternating vertical pull movements and oblique ones (as in Fig. 10.8). When the vessel, still in partially plastic conditions, was detached from its mould and lifted with a rapid rotating movement, the mid-wall, thinner than the rest, often retained a spiral-like twist. 65 Under the outer rim there are often deep, rhythmic finger impressions, possibly left while forming the rim, but also during the detachment. The uneven thickness caused frequent cracks during drying, particularly within the base. The residual plasticity of BRBs at the moment of their extraction suggests that they were quickly made in large lots and extracted after a short interval - potentially within one hour. The firing conditions are in general even, as a rule in slightly oxidising atmospheres, and do not produce blackish spots on the vessel surface.

The Mahtoutabad flowerpots are strange vesselsvery thick and sturdy at the base, and extremely fragile at the slightly thickened rim, to the point that it is hard to imagine that they had a long life. As a rule, they seem to have been fashioned from a single lump centred on the potter's wheel, but one large specimen was first made by moulding its base as a finished BRB. ${ }^{66}$ This ostensible BRB was extracted from its mould and placed, before drying, on the potter's wheel and raised through the addition of a series of superimposed large coils on the base. The now tall vessel was then finally shaped on the fast-revolving wheel (a particularly clear example of "hybrid" technology).

It was once thought that BRBs were products of a somehow brutal, non-skilled serial labour, but this, on the contrary, suggests that their making was simply a part of a still complex technical know-how of the potting communities of the time. In the same workshop areas, potters shifted from slab moulding to wheel throwing, even within the same production cycles. Another example of this complexity is the long bottles with downward-bent spouts and truncated-conical turned bases of Susiana, which were doubtless made by coil-building and shaping on the potter's wheel and built in superimposed sections; but perhaps we should

65 The same defect is clearly recognised in some BRBs from Godin Tepe (e.g. Badler 2002: fig. 13, B1 479 no. 1 and B1 479 no. 5).

66 As described in Vidale 2011. 
not assume that the Mahtoutabad examples were made locally.

Oval trays were made with the same chaff-tempered material, but were entirely hand-fashioned with slabs in the base, and with one or two coils for the wall and rim. The bottom often retains deep finger tracks. The use of large and flat moulds for the bases is possible but hard to demonstrate.

The finer small-sized vessels were entirely fashioned on the potter's wheel, and their bases were later thinned by placing them upside down on the same device and thinning them by turning the bases with a blade, before the vessels were completely dry. The finer small painted bowls were frequently polished to a variable extent before painting and firing.

With the exception of the BRBs and low-sided trays, the Mahtoutabad III pottery shares medium and often quite fine fabrics with scarcely visible inclusions, and firing was distinguished by medium-high temperatures reached in slightly reducing atmospheres, often resulting in shadows from white or light buff to pale yellow or even light green. The ware was typically compact and clinky. The general impression is of a competent, rather standardised mass production; potters mastered a combination of hand forming, moulding, coiling and wheel-throwing techniques, with little aesthetic concern but with highly controlled firing processes.

\section{OTHER FINDS}

A limited number and range of other finds were recovered. Animal figurines (Fig. 25.1-2) include a small, well-fired terracotta specimen that might have portrayed a fat-tailed sheep, and the head of a larger terracotta bull, the original of which must have been about $15 \mathrm{~cm}$ long or more. The bull was modelled in massive form and was painted with dark stripes, while the front bears multiple impressed dots.

The small finds assemblage also contained three median fragments of terracotta sickles (one reconstructed in Fig. 25.3-5). These artefacts are typical of Ubaid Mesopotamia, but are rather uncommon in the fourth-millennium $\mathrm{BC}$ contexts discussed so far (i.e. they have never been found at Tal-e Malyan, Arisman or Tepe Yahya). They have a distinctive drop-shaped section, one of the surfaces was covered with sand (possibly for an easier detachment from the kiln's

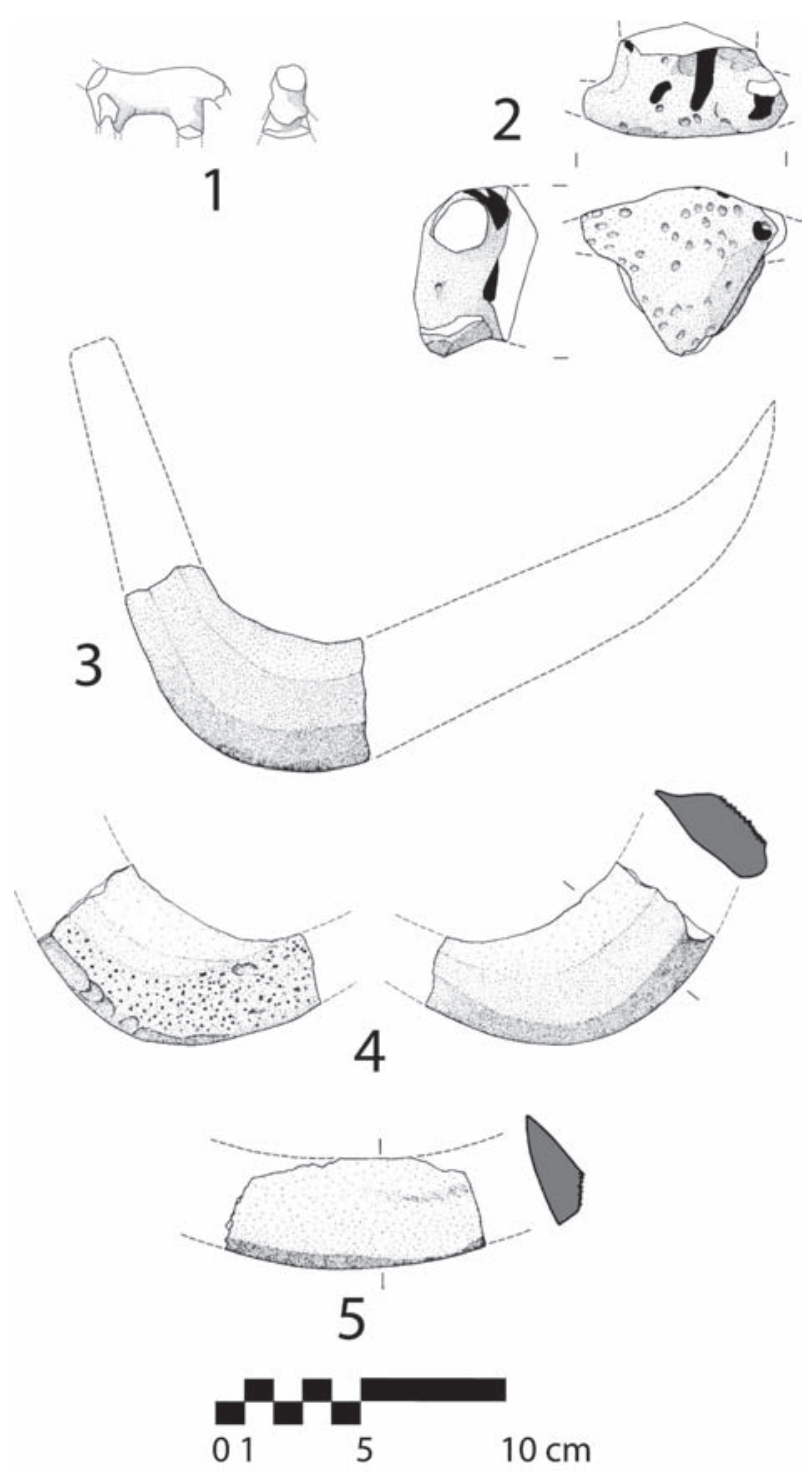

Fig. 25. Terracotta figurines and sickles. 1. Terracotta animal (sheep ?) figurine fragment, length c. $6 \mathrm{~cm}$.

2. Terracotta bull (?) figurine fragment, length c. $15 \mathrm{~cm}$. 3. Terracotta sickle fragment. 4. Terracotta sickle fragment. 5. Terracotta sickle fragment. (Image M. Vidale, F. Desset and $R$. Micheli.)

surface) and they appear to have been fired at high temperatures.

Figure 26 shows a collection of jar stoppers or lids in unbaked clay (1-8) and two seal impressions in the same material (9 and 10). All of these objects were found clustered in a restricted spot of Trench $\mathrm{V}-\mathrm{a}$ primary dump of sealings and some complete BRBs - in front of the alluvial deposits (see Fig. 5). 
The lids (Fig. 26.1-4) are small clay disks, sometimes retaining the edge and a convex profile, which might have been used to close and re-open small- to medium-sized restricted containers. Very similar objects of the same size were found in large numbers at Chogha Mish ${ }^{67}$ and were also used at Godin Tepe and Tal-e Malyan. 68 Their diameters seem to have ranged between 5 and $10 \mathrm{~cm}$. While no closure of this general type could be ascribed to the mouth of a BRB, Figure 26.5 retains the possible imprint of a basket, and Figure 26.6-8 had been clearly applied on the neck of restricted jars (Fig. 26.6 also retains a cloth impression on the interior). ${ }^{69}$ Objects bearing seal impressions (Fig. 26.9-10) are fragments of flat clay sheets that might have been applied to wooden boxes or similar packages. Figure 26.9, which was probably produced by the use of a cylinder seal, shows a long-horned goat framed by vertical lines. Figure 26.10, which was also impressed with a cylinder seal but is poorly preserved, retains some fine scrolls, and the edge of the impression is marked by one or two lines of dots in relief.

Two fragments of perforated weights in travertine are illustrated in Figure 27. Both were found in the same layer, together with pieces of BRBs, flowerpots and other vessel forms. The original shape of the weights was hypothetically reconstructed by combining the formal information of both finds (Fig. 27.3 and design at the bottom).

\section{DISCUSSION}

East of the plains of Mesopotamia, ceramics generically qualified as "Uruk-related" 70 have been recovered in several regions and sites (Fig. 1). ${ }^{71}$ These include: Susa (periods II and III);72 Chogha Mish (proto-

67 Delougaz and Kantor 1996: pl. 130.

68 Rothman and Badler 2011: fig. 4.52; Sumner 2003: fig. 42, b.

69 See the graphic reconstruction in Delougaz and Kantor 1996: pl. 131.

70 Particularly the complexes containing BRBs, low-sided trays, nose-lugged jars, flowerpots (Blumentopfen), ovoid elongated jars with bent, down-inflected spouts and terracotta sickles.

71 See Potts D.T. 2009: 15-17, table 1.

72 Stève and Gasche 1971: pls. 24-32 and 83-88 (excavation on the Acropole); Le Brun 1971: figs. 47, 49-53, 60, 66; 1978a: figs. 20-21, 24, 28-33; 1978b: figs. 32, 34, 36 (Acropole I yard); Canal 1978: fig. 26 (Acropole II); De Miroschedji 1976; Stève and Gasche 1990: pls. 4-5 and 8-9 (yards 24 and 25 of the Apadana).
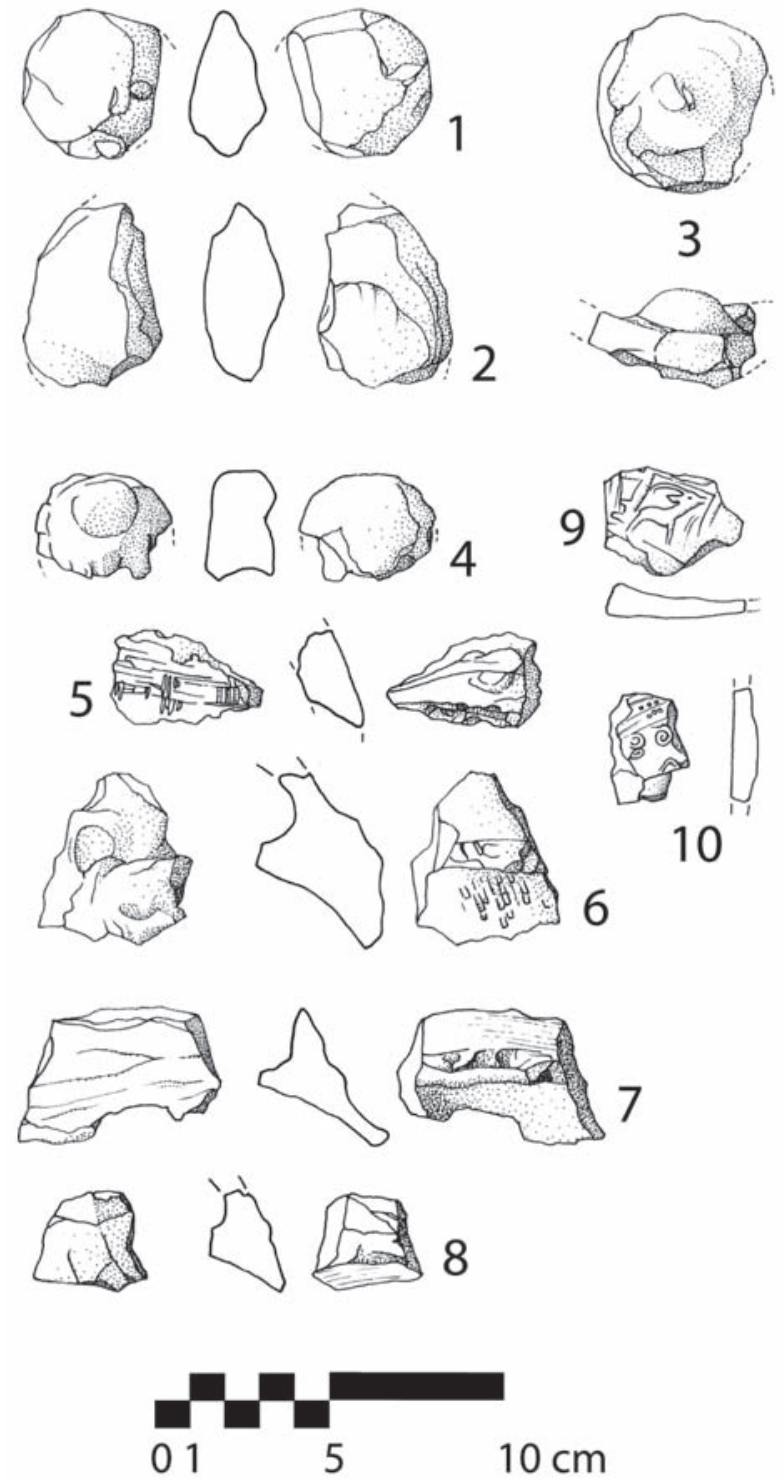

Fig. 26. Unbaked clay lids and sealings. 1. Round jar stopper, diam. $4.2 \mathrm{~cm}$, thick. $2.2 \mathrm{~cm}$. 2. Fragment of round (?) jar stopper, diam. greater than $5.4 \mathrm{~cm}$, thick. $2.2 \mathrm{~cm}$. 3. Round jar stopper, diam. $5.2 \mathrm{~cm}$, thick. c. 3 $\mathrm{cm}$. 4. Round jar stopper, diam. $3.8 \mathrm{~cm}$, thick. $1.9 \mathrm{~cm} .5$. Fragment of a clay sealing applied to the rim of a basket, thick. $1.4 \mathrm{~cm}$. 6. Fragment of a clay sealing applied to the rim of a restricted jar, with cloth impression at the height of the shoulder, thick. $3.4 \mathrm{~cm}$. 7. Fragment of a clay sealing applied to the rim of a restricted jar, thick. $2.5 \mathrm{~cm}$. 8. Fragment of a clay sealing applied to the rim of a restricted jar, thick. $1.8 \mathrm{~cm}$. 9. Fragment of a sealing with a seal impression, possibly applied onto a box, thick. $0.8 \mathrm{~cm} .10$. Fragment of a sealing with a cylinder (?) seal impression, possibly applied onto a box, thick. $0.8 \mathrm{~cm}$. (Image M. Vidale and F. Desset.) 

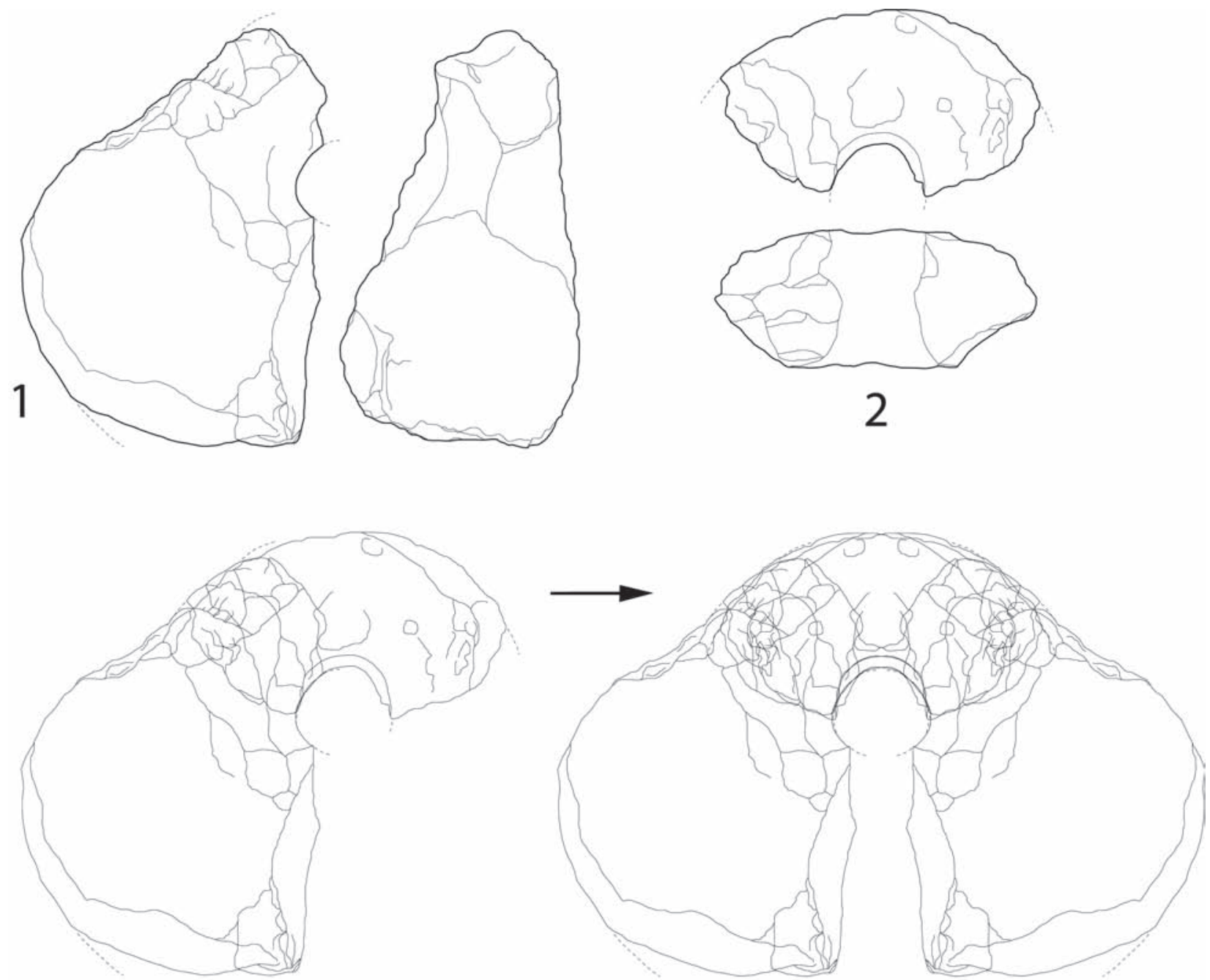

3
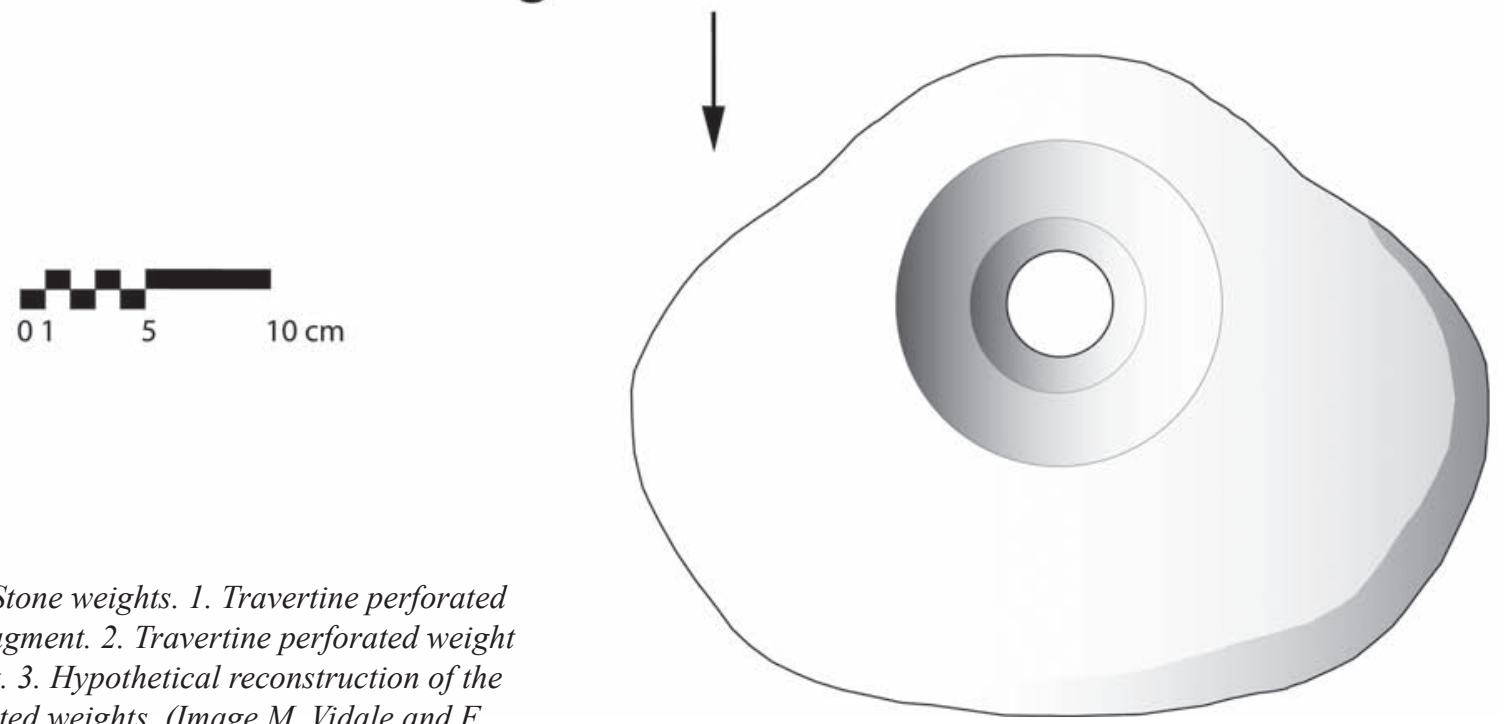

Fig. 27. Stone weights. 1. Travertine perforated weight fragment. 2. Travertine perforated weight fragment. 3. Hypothetical reconstruction of the perforated weights. (Image M. Vidale and F. Desset.) 
literate period) ${ }^{73}$ and Tepe Sharafabad in Susiana; 74 Tal-i Ghazir75 on the Ram Hormouz plain; Tepe Farukhabad 76 on the Deh Luran plain; Kamtarlan; 77 Chogha Gavaneh; Godin Tepe ${ }^{78}$ and three other sites ${ }^{79}$ in the valley of Kangavar; 11 sites with BRB sherds on the surface 80 in Kermanshah/Mahidasht, Chia Fatela and Chesmeh Sardeh near Tepe Guran in Hulailan; Tepe Giyan ${ }^{81}$ and Baba Jan V82 in Nehavand; three sites with Uruk-related materials 83 in Khorammabad, Tepe Ghabrestan (period IV, levels 3-1) 84 and Tepe Ozbaki/Tepe Marral ${ }^{85}$ in the Tehran ${ }^{86}$ and Qazvin plains; Tepe Sofalin 87 in the Pishva-Varamin plain; Qoli Darvish; 88 Tepe Sialk (period IV) ${ }^{89}$ and Aris$\operatorname{man}^{90}$ on the Central Plateau; Tol-e Nurabad and Tol-e Spid in the Mamasani region; ${ }^{91}$ Tal-e Malyan (middle and late Banesh) ${ }^{92}$ and Tal-i Kureh (initial/early Banesh) ${ }^{93}$ in the Kur River Basin; Tepe Yahya (phase

73 See in general Delougaz and Kantor 1996; Alizadeh 2008.

74 Wright et al. 1980; Wright 2007: 181-182.

75 Caldwell 1968a: 350 and figs. 19-27, 31 and 39; Whitcomb 1971.

76 Wright 1997; Voigt and Dyson 1992, 1: 128.

77 Schmidt et al. 1989: 16, pl. 73.

78 Weiss and Young 1975: fig. 3; Young 1986: figs. 2-3; Young and Levine 1986: figs. 21-22; Badler 2002: figs. 7, 9-10, 13 and 17; Rothman and Badler 2011.

79 Young 1986: 218; Young and Levine 1986: 39; Young 2004: 648 .

80 Young 1986: 218; Young and Levine 1986: 39.

81 A fragment of BRB published in Contenau and Ghirshman 1935: pl. 15, no. 5; see also Young 1986: 220; Young and Levine 1986: 39.

82 Goff 1976: 24.

83 Hole 2007: 74.

84 Madjidzadeh 2008: 76, figs. 43-44 and 47.

85 Madjidzadeh 2001: 45; Azarnoush and Helwing 2005: 206.

86 Fazeli and Abbasnezhad Sereshti 2005: 18; Helwing 2005b: 48.

87 Hesari and Akbari 2007; Hesari 2011.

88 Azarnoush and Helwing 2005: 206-207.

89 Ghirshman 1938/1939, 1: pls. 26 and 88-89; Amiet 1985: figs. 1-2 and 4; 1986: figs. 54-55; Shahmirzadi 2002: pls. 1-2; 2003: pl. 3. Helwing (2005b: 45) has noted that during recent Iranian excavations, BRBs and nose-lugged jars were found in phase III, 6-7.

90 Chegini et al. 2000: 297; Helwing 2005a: fig. 8; 2005c: fig. 7; Helwing 2011a.

91 Petrie et al. 2009b: 174-176.

92 For TUV see Nicholas 1990; pls. 13-14; for ABC, see Sumner 2003: figs. 22-23.

93 Alden 2003a.
IVC); 94 Tal-i Iblis (periods IV-VI) ${ }^{95}$ and Mahtoutabad (period III) in Kerman; and a small number of BRBs have also been found in Kech-Makran, at Miri Qalat (period IIIa; end of the fourth/ beginning of the third millennium BC). ${ }^{96}$ So far no Uruk-related pottery type was reported in the plains of Damghan and Gorgan, in Khorasan or in the Kopet Dagh piedmont, in the Hilmand basin or in the basin of the Urmia Lake. ${ }^{97}$

A general review of the detailed absolute dates of the mentioned sites is beyond the scope of this article. Nonetheless, it is clear that from c. $3500 \mathrm{BC}$ or possibly even earlier (as suggested, for example, by the determinations from Tepe Sharafabad, Tol-e Spid and Tol-e Nurabad; see Petrie in press), several ceramic types generally associated to the contemporary ceramics produced in lowland Mesopotamia (in the first place the BRBs) appeared, often en masse, on the Iranian plateau.

In sites like Tol-e Spid, Tol-e Nurabad and Tal-e Kureh, where the distinction between the late Lapui and initial Banesh phases is not straightforward, at Tal-i Iblis where Period IV is poorly defined or at Tepe Sialk where Uruk-related material was actually found in late Period $\mathrm{III}_{6-7}$, these vessels forms appear without any clear break with the previous traditions. In contrast, the Mahtoutabad III secondary layers came from a site apparently isolated from previous or later occupations. The clay sealings, the pottery forms recorded and the broken travertine weights qualify the area as a dump after the completion of a variety of small-scale controlled transactions involving different types of containers (small jars, possibly baskets and wooden boxes). Containers were frequently opened and closed, while large numbers of BRBs circulated and were discarded on the spot. With the exception of the possible rectangular copper moulds discussed above, we found no material evidence of specific craft activities, and the apparent absence of large-sized jars (see above) might play against the hypothesis of an important long-term storage facility.

94 Potts D.T. 2001: figs. 1.10, 1.22, 1.24, 1.40, 1.43, 2.6, 2.1920 and 3.13-14 (nose-lugged jars and low-sided trays until Phase IVB6). According to Lamberg-Karlovsky (1972: 97; 1973: 28), Uruk-related materials appeared from Phase VA, although this is not fully confirmed by the publication of this context (Beale 1986).

95 Caldwell 1967: 37-38; Chase et al. 1967: figs. 24, 26, 29 and 39.

96 Besenval 1997: 18-19.

97 Danti et al. 2004: 595-597. 
While the Uruk-related ceramic complexes found in Iran have often been described as being indicative of a single, pervasive interaction sphere centred in the west, the new Mahtoutabad III assemblage reveals a complex and intriguing pattern of interference, particularly through evidence of links but also important gaps with the other involved sites. In the first place, the formal identity of some types of carinated fourlugged jars, terracotta sickles and tall jars with bent spouts suggests a preferential, possibly non-mediated link between the Halil Rud valley and the Susiana and/ or Mesopotamian centres. Terracotta sickles, which derive from an ancient Mesopotamian tradition of the fifth millennium $\mathrm{BC}$, are intriguing, because on the Iranian plateau the abundance of silicastic rocks needed for blade manufacturing would rule out the techno-economical need of making ceramic sickles. Widely used across the Susiana plains in the fourth millennium BC, particularly in the early and middle Uruk period, ${ }^{98}$ ceramic sickles might have been required in the Halil Rud valley for a specific technical process, beyond harvesting cereals. Nonetheless, while many have hypothesised that the reason for the "Uruk phenomenon" was intercepting local flows of raw materials at the highland sources, ${ }^{99}$ terracotta sickles would rather show an opposite attitude, that is carefully avoiding local materials and technologies in favour of a technique doubtlessly rooted in alluvial geomorphological contexts with limited access to flint, chert and similar rocks.

At Arisman and Tepe Yahya, four-lugged jars were replicated in terms of local, regional traditions, while at Godin Tepe four-lugged jars with incised decoration identical to the western models and local painted variants were both encountered. Similarly, the strap-handled pots with grooved shoulder common at Mahtoutabad III point to a straight connection with the west, whereas the "contemporary" communities at Godin Tepe and Arisman seem to have recreated their own versions of the same model. Some types point to links in other directions. Flowerpots, for example, might link Mahtoutabad with several Mesopotamian sites, but not to the wide repertory of Chogha Mish. Mahtoutabad shares this tall vessel with Tal-e Malyan and Tepe Sialk, but apparently to the exclusion of other sites like Tepe Yahya and Arisman. Besides

98 Delougaz and Kantor 1996, I, 106. For their manufacture and possible multi-functional use, see Benco 1992.

99 e.g. Algaze 1993.
BRBs, low-sided trays are probably the most ubiquitous type, but in both cases more detailed typological studies might reveal variations in form, function and chronology that are at present still implicit.

\section{CONCLUSIONS}

As with all of the sites discussed here, the fragmentary picture that has been observed might be an artefact of the relative size of the excavated areas, location, activity patterns and stratigraphic formation processes at the various excavated sites. Each assemblage, furthermore, might be the casual contingency of a specific historical event, deformed by the partiality of the preserved and excavated lots. Even the shape and tectonics of each pottery type, as discussed above, which in turn depends on manufacturing technology, may dramatically affect our counts and reconstructions. All this becomes even more slippery when the still scarce chronological definition of the involved horizons is considered, as we are dealing with a time range of several centuries, for which absolute dates show a wide range of fluctuation. 100

Two crucial questions, however, cannot be eluded: exactly how old is the pottery of Mahtoutabad III (if it actually is a synchronous assemblage)? And what is the historical explanation, or the economical raison d'être of the community that used these peculiar ceramics at the piedmont of the first mountain ranges of Baluchistan?

The chronology of the Mahtoutabad III assemblage is a difficult issue. In the absence of absolute dates, we can only compare our ceramics and related dates with those from other excavated sites. As we have seen, both the pottery sickles found in Trench V and the probable links with Susa Acropole I.17 and the Early Banesh in Kur River Basin would point to a mid-fourth-millennium $\mathrm{BC}$ date, which is supported by further positive comparisons with Arisman Area B outlined above, which is in turn linked with Sialk III $_{6-7}$.

The validity of pottery links can be questionable, because the formal comparison of graphic illustrations has an inescapable component of subjectivity, and stratigraphy is recorded at variable levels of analytical confidence. Nevertheless, we appear to have traced very early evidence of the use of several Uruk-related ceramic types at a surprising distance from southern

100 Petrie in press. 
Iraq, close to the still mysterious frontier with the early Indus world. The Halil Rud floodplains seem somehow to have been linked to Khuzistan at the beginning of the urban explosion of Uruk and Susa, but the form and rationale for this linkage is at present unclear.

In the past, the "Uruk phenomenon" outside Mesopotamia has been discussed at length. ${ }^{101}$ In a minimalistic view, similarities in pottery are seen as simply being due to cultural influence from Mesopotamia, 102 while more demanding theories suggest that pottery and its models were transported from Mesopotamia eastwards and northwards by human groups shifting on the wake of variable interests. ${ }^{103}$ For the Iranian plateau the most relevant explanations have been reviewed by Petrie (2013a), highlighting the arguments about communication, shared cultural milieus, strategic control of interregional trade, elite emulation, migration and colonisation, and more recent tradediaspora models, which are distinguished by reciprocal or mutually exploitative relationships, to account for decreasing levels of political control and lesser cultural uniformity with increasing distances.

In most of these models, the asymmetric distribution of natural resources (in the first place of copper, lead and silver ores) between lowlands and highlands plays a major explanatory role. But how does the Mahtoutabad III evidence fit in with such a theoreti-

101 e.g. Edens 2002: 40; Butterlin 2003: 139-151; Potts D.T. 2009: 7-14.

102 For Forest (2000: 142) the diffusion of BRBs could simply be the result of the diffusion of a peculiar ceramic manufacturing technique.

103 Amiet (1986: 49) has argued that this involves the migration of small groups of craft specialists. D.T. Potts (1999: 65-67) has hypothesised a limited migration from Mesopotamia to Susiana, without attempts at politically controlling the region. In contrast G. Algaze (1989, 1993, 2001, followed by Potts T.F. 1994: 78) thinks that Susiana was conquered by Mesopotamian polities of the Uruk period, establishing a linked series of outposts as trade enclaves for controlling the exploitation of local resources. For Englund (2006: 7) the procurement of such goods took place in "politically undeveloped mountainous regions, not encumbered by ownership claims". Kohl (2007: 222-23) proposed a growing interest for new breeds of sheep and goats and better qualities of wool available from the Caucasus to the plateau, while for Lamberg-Karlovsky (2008) masses of farmers abandoned Sumer in search of better and free agricultural estates in foreign lands. No one, however, discusses the functions of the Uruk-related ceramic types in relation to the activities and socio-economic processes hypothesised to explain the expansion. cal framework? Archaeological evidence at the Konar Sandal site complex shows intensive exploitation of copper ores in a specialised craft neighbourhood during the second half of the third millennium $\mathrm{BC}, 104$ and other important metallurgical settlements are known in the Halil Rud valley in the later historical periods (surveys by N. Alidadi Soleimani). That the Halil Rud communities of the mid-fourth millennium $\mathrm{BC}$ were similarly involved in the procurement and transformation of local copper and lead/silver ores - as at Tepe Sialk and Arisman ${ }^{105}$ - is quite likely, but our only witnesses to this are two fragments of rectangular moulds for casting copper (Fig. 18.3). On the other hand, a limited test trench in the much-disturbed Mahtoutabad I occupation layers showed that local societies were actively involved in the production of alabaster vessels and in copper processing already in the late fifth-early fourth millennium BC, 106 well before the Uruk phenomenon. In this (very partial) light, the interference of the communities using the Uruk-related vessels seems to be a consequence, and not a causative factor, of local processes of socio-economical evolution. Moreover, the striking similarity of the ceramics we described to the Khuzistan assemblages, at a site more than $1000 \mathrm{~km}$ east of Susa, does not fit easily with models envisaging decreasing cultural interaction with increasing geographical distance, and poses challenging new questions in our efforts at archaeological interpretation.

Ultimately, the meaning that we should attribute to the appearance of these wares across the Iranian plateau, and the significance that should be given to the material links with Mesopotamia-where such ceramics might have been previously produced 107 _most probably cannot be properly discussed on the basis of the relatively

104 Madjidzadeh and Pittman 2008: 86 (trench IX).

105 See Helwing 2013.

106 Vidale and Desset 2013.

107 See Wright and Rupley 2001 for the dating of the "Urukrelated assemblages" in southern Iraq. The anteriority of these material complexes west of the Iranian plateau is not supported by the data. The oldest assemblages of this type, and in particular of BRBs (markers of the middle Uruk phase) come from the sites of Abu Salabikh and Tell Qraya. Dates of Abu Salabikh range from c. 3950-3660 BC to 3650-3380 BC; while at Tell Qraya c. 3900-3370 BC, 3940-3380 BC and 3950-3380 BC (all calibrated, 95\% probability). The radiocarbon datings of Tepe Sharafabad, Tol-e Spid and Tol-e Nurabad are contemporaneous with those of Abu Salabikh and Tell Qraya. 
threadbare evidence that is presently available. $108 \mathrm{We}$ should, however, continue to deconstruct previous concepts and get back to the hard core of the material evidence, as this will force many traditional models to be thoroughly revised. For example, reference to the intercepting of raw materials should be supported by evidence of storage facilities for the same goods, or to the factual record of local large-scale transformation activities (e.g. indicators of textile processing or of copper-smelting processes), and not to proximity to trade routes and potential geopolitical entities. Also, Urukrelated ceramic types should be interpreted in terms of their function, social role and gender ascription, rather than their formal description.

The daily material aspects of a society (which may be found in excavations, such as ceramic production, glyptic, architecture or writing) are not necessarily intertwined in a monothetic structure. They may well have evolved independently, with various speeds and adapted differently, in contexts whose contemporaneity is still beyond our present power of archaeological assessment.

While the "Uruk-related" ceramic types appeared in various regions of the Iranian plateau around 3500 $\mathrm{BC}$ (or even before), there are in Iran no architectural structures comparable to what is observed in Greater Mesopotamia, as would be the case in a true colonisation. ${ }^{109}$ In the second half of the fourth millennium $\mathrm{BC}$ the site of Godin Tepe, frequently quoted as an example of supporting evidence for an "Uruk expansion", shows rather surprising and important architectural similarities with buildings excavated in Tal-e Malyan and Susa (F. Desset, ongoing research). At the same time, however, Godin Tepe and Tal-e Malyan are likely to be slightly different in date and used different systems of graphic recording: the former had numeral and numero-ideographic writing, the latter ProtoElamite writing. In short, we face a very complex, multi-faceted and badly preserved archaeological reality, and given the very poor control we still have of the absolute chronology, to accept our ignorance in principle seems more useful than embracing grander, more adventurous reconstructions.

108 See the criticism of Pollock (2010: 107) concerning the "sterile debates about the meanings of archaeological entities".

109 In contrast, at Habuba Kabira and Djebel Aruda in Syria, populations shared all the material aspects of the southern Mesopotamian way of living (primarily, architecture); in these contexts, many would agree that the use of the term "colony" is not excessive.
The evolution of the material culture of fourthmillennium BC Middle Asia should be considered in terms of an unparalleled but still largely unknown process of discontinuous interregional standardisation that affected in different phases and to different scales ceramics, glyptic, architecture and writing. The ceramics of Mahtoutabad III, with their intriguing framework of formal identity, similarities, differences and relationships of presence and absence with important pottery types with other sites and across distant regions, are a new fragment of this developing picture.

\section{Acknowledgements}

This text has been greatly improved by the sharp and very constructive criticism of the anonymous referees. To them, and to the patience of the editor, our warmest thanks are due.

François Desset
UMR 7041 ArScAn,
Maison RenéGinouvès,
21 allée de l'Université
92023 Nanterre,France
francois.desset@wanadoo.fr
Massimo Vidale
Dept.ofCultural Heritage: Archaeology, History of
Art, Cinema and Music
University of Padua
Piazza Capitaniato 7, I-35139
Italy
massimo.vidale@unipd.it
Nader_Alidadi Soleimani
ICCHTO, Kerman
nader_134982@yahoo.com

\section{Bibliography}

Alden, J.R. 2003a. “Appendix D - Excavations at Tal-e Kureh", in William M. Sumner (ed.), Early Urban Life in the Land of Anshan: Excavations at Tal-e Malyan in the Highlands of Iran, Malyan Excavation Reports, Series editor, vol. III, University Museum Monograph 117, University of Pennsylvania, Philadelphia: 187-98.

- 2003b. "Appendix E - Inventory of Banesh Sites", in William M. Sumner (ed.), Early Urban Life in the Land of Anshan: Excavations at Tal-e Malyan in the Highlands of Iran, Malyan Excavation Reports, Series editor, vol. 
III, University Museum Monograph 117, University of Pennsylvania, Philadelphia: 199-204.

Algaze, G. 1989. "The Uruk Expansion: Cross-Cultural Exchange in Early Mesopotamian Civilization", Current Anthropology 30: 571-608.

- 1993. The Uruk World System: Dynamics of Expansion of Early Mesopotamian Civilization, The University of Chicago Press, Chicago.

- 2001. "The Prehistory of Imperialism: the Case of Uruk period Mesopotamia", in M.S. Rothman (ed.), Uruk Mesopotamia and its Neighbors, School of American Research Advanced Seminar Series, School of American Research, Santa Fe: 27-84.

Alizadeh, A. 2008. Chogha Mish II, the Development of a Prehistoric Regional Center in Lowland Susiana, Southwestern Iran: Final Report on the Last Six Seasons of Excavations, 1962-1978, Oriental Institute Publications, vol. 130, The Oriental Institute of the University of Chicago, Chicago.

Amiet, P. 1985. "La période 4 de Tépé Sialk reconsidérée", in J.-L. Huot, M. Yon and Y. Calvet (eds.), De l'Indus aux Balkans, Recueil à la mémoire de Jean Deshayes, ERC, Paris: 293-312.

- 1986. L'âge des échanges inter-iraniens, 3500-1700 avant J.-C., notes et documents des Musées de France 11, Éditions de la réunion des musées nationaux, Paris.

Azarnoush, M. and Helwing, B. 2005. "Recent archaeological research in Iran; prehistory to iron age", AMIT 37: 189-246.

Badler, V.R. 2002. "A chronology of Uruk artefacts from Godin Tepe in central western Iran and implications for the interrelations between the local and foreign cultures", in J.N. Postgate (ed.), Artefacts of Complexity, Tracking the Uruk in the Near East, Iraq Archaeological Reports 5, British School of Archaeology in Iraq, Cambridge: 79-109.

Beale, T.W. 1986. Excavations at Tepe Yahya, Iran, 19671975, The Early Periods, American School of Prehistoric Research, Bulletin 38, Peabody Museum, Harvard University, Cambridge, MA.

Benco, N.L. 1992. "Manufacture and use of clay sickles from the Uruk mound, Abu Salabikh, Iraq", Paléorient 18/1: 119-34.

Besenval, R. 1997. "Entre le Sud-Est iranien et la plaine de l'Indus: le Kech Makran, Recherches archéologiques sur le peuplement ancien d'une marche des confins indoiraniens", Arts Asiatiques 52: 5-36.

Butterlin, P. 2003. Les temps proto-urbains de Mésopotamie; contacts et acculturation à l'époque d'Uruk au MoyenOrient, CNRS Éditions, Paris.

Caldwell, J.R. 1967. "The setting and results of the Kerman project”, in J.R. Caldwell (ed.), Investigations at Tal-i Iblis, Illinois State Museum preliminary reports no. 9, Springfield: $21-40$.

- 1968a. "Ghazir, Tell-i", Reallexikon der Assyriologie und vorderasiatischen Archäologie 3: 348-55.

- 1968b. "Tal-I-Iblis and the beginning of copper metallurgy at the fifth millennium", Archaeologia viva 1: 145-50.

Canal, D. 1978. "La haute terrasse de l'Acropole de Suse", Paléorient 4: 169-76.
Chase, D.W., Caldwell, J.R. and Fehervari, G. 1967. "The Iblis sequence and the exploration of excavation A, C and E", in J.R. Caldwell (ed.), Investigations at Tal-i Iblis, Illinois State Museum preliminary reports no. 9, Springfield: 111-201.

Chegini, N.N., Momenzadeh, M., Parzinger, E., Pernicka, E. et al. 2000. "Preliminary report on archaeometallurgical investigations around the prehistoric site of Arisman near Kashan, western central Iran", AMIT 32: 281-318.

Contenau, G. and Ghirshman, R. 1935. Fouilles du Tepe Giyan, près de Nehavend, 1931 et 1932, Musée du Louvre, Département des antiquités orientales, Série archéologique tome III, Paul Geuthner, Paris.

Danti, M.D., Voigt, M.M. and Dyson, R.H. 2004. "The search for the late Chalcolithic/Early Bronze Age transition in the Ushnu-Solduz valley, Iran", in A. Sagona (ed.), A View from the Highlands, Archaeological Studies in Honour of Charles Burney, Ancient Near Eastern Studies, supplement 12, Peeters: 583-616.

De Miroschedji, P. 1976. "Un four de potier du IVème millénaire sur le tell de l'Apadana à Suse", CDAFI 6: 13-45.

Delougaz, P. and Kantor, H.J. 1996. Chogha Mish vol. I, the First Five Seasons of Excavations 1961-1971, ed. A. Alizadeh, Oriental Institute Publications, vol. 101, The Oriental Institute of the University of Chicago, Chicago.

Edens, C. 2002. "Small things forgotten? Continuity amidst change at Godin Tepe", IA 37: 31-45.

Englund, R.K. 2006. “An examination of the 'textual' witnesses to late Uruk world systems", in Y. Gong and Y. Chen (eds.), A Collection of Papers on Ancient Civilizations of Western Asia, Asia Minor and North Africa, Beijing: 1-38.

Fazeli, H. and Abbasnezhad Sereshti, R. 2005. "Social transformation and interregional interaction in the Qazvin plain during the 5th, 4th and 3rd millennia B.C.", AMIT 37: $7-26$.

Forest, J.D. 2000. “L'expansion urukéenne: notes d'un voyageur", Paléorient 25/1: 141-49.

Fouache, E., Garçon, D., Rousset, D., Senechal, G. and Madjidzadeh, Y. 2005. "La vallée de l'Halil Roud (région de Jiroft, Iran): étude géoarchéologique, méthodologie et résultats préliminaires", Paléorient 31: 107-22.

Ghirshman, R. 1938/1939. Fouilles de Sialk, près de Kashan, 1933, 1934, 1937, 2 vols., Musée du Louvre, Département des antiquités orientales, Série archéologique tome IV, Paul Geuthner, Paris.

Goff, C. 1976. "Excavations at Baba Jan: the Bronze Age occupation", Iran 14: 19-40.

Goulder, J. 2010. “Administrators' bread: an experiment-based re-assessment of the functional and cultural role of the Uruk bevel-rim bowl", Antiquity 84: 351-62.

Helwing, B. 2005a. "Early mining and metallurgy on the western Iranian Plateau: firsts results of the Iranian-German archaeological research at Arisman, 2000-2004", AMIT 37: 425-34.

- 2005b. "Early complexity in highland Iran: recent archaeological research into the Chalcolithic of Iran", Tüba-ar 8: 39-60.

- 2005c. "Long-distance relations of the Iranian highland sites during the late Chalcolithic period: new evidence from 
the joint Iranian-German excavations at Arisman, prov. Esfahan, Iran", South Asian Archaeology (2003): 171-78.

- 2011a. "Proto-Elamite pottery from areas A, C, D and E", in A. Vatandoust, H. Parzinger and B. Helwing (eds.), Early Mining and Metallurgy on the Western Central Iranian Plateau, the First Five Years of Work, Archäologie in Iran und Turan, band 9, Verlag, Philipp von Zabern, Mayence: 196-253.

- 2011b. "The small finds from Arisman", in A. Vatandoust, H. Parzinger and B. Helwing (eds.), Early Mining and Metallurgy on the Western Central Iranian Plateau, the First Five Years of Work, Archäologie in Iran und Turan, band 9, Verlag, Philipp von Zabern, Mayence: 254-327.

- 2013. "Some thoughts on the mode of culture change in the fourth millennium BC Iranian highlands", in C. Petrie (ed.), Ancient Iran and Its neighbours: Local Developments and Long Range Interactions in the Fourth Millennium $B C$, British Institute of Persian Studies Archaeological Monographs Series III, Oxbow Books, Oxford: 93-105.

Hesari, M. 2011. "New evidence of the emergence of complex societies discovered on the Central Iranian Plateau", Iranian Journal of Archaeological Studies 1/2: 35-48.

Hesari, M. and Akbari, H. 2007. "Gozâresh-e moghadamâti-e kavosh-e mohavateh bastani Sofalin, Pishva (Preliminary report on the excavations of the archaeological site of Sofalin, Pishva)", The 9th Annual Symposium on Iranian Archaeology, Archaeological reports 7, Research center for ICHHTO, Iranian center for archaeological research (ICAR): 165-200.

Hole, F. 2007. "Cycles of settlement in the Khorramabad valley in Luristan, Iran", in E.C. Stone (ed.), Settlement and Society, Essays Dedicated to Robert McCormick Adams, Cotsen Institute of Archaeology, Ideas, debates and perspectives vol. 3, Cotsen Institute of archaeology, University of California, Los Angeles and the Oriental Institute of the University of Chicago: 63-82.

Kohl, P.L. 2007. The Making of Bronze Age Eurasia, Cambridge World Archaeology, Cambridge University Press, Cambridge.

Lamberg-Karlovsky, C.C. 1972. “Tepe Yahya, 1971. Mesopotamia and Indo-Iranian Borderlands", Iran 10: 89-100.

- 1973. Urban Interactions on the Iranian Plateau: Excavations at Tepe Yahya, 1967-1973, Proceedings of the British Academy LIX, Oxford University Press, London.

- 2008. "A Brutal Social Landscape. Mesopotamian Civilization as Exclusive and Exploitative?", The Review of Archaeology 29: 1-12.

Lamberg-Karlovsky, C.C. and Tosi, M. 1973. "Shahr-i Sokhta and Tepe Yahya: Tracks of the Earliest History of the Iranian Plateau", East and West 23: 21-53.

Le Brun, A. 1971. "Recherches stratigraphiques à l'Acropole de Suse, 1969-1971", CDAFI 1: 163-216.

- 1978a. "Le niveau 17 B de l'Acropole de Suse (campagne de 1972)", CDAFI 8: 57-154.

- 1978b. "La glyptique du niveau 17 B de l'Acropole (campagne de 1972)", CDAFI 8: 61-79.

Madjidzadeh, Y. 2001. "Les fouilles d'Ozbaki (Iran).
Campagnes 1998-2000", Paléorient 27/1: 141-45.

- 2008. Excavations at Tepe Ghabristan, Iran, Reports and memoirs, new series VII, IsIAO, Rome.

Madjidzadeh, Y. and Pittman, H. 2008. "Excavations at Konar Sandal in the region of Jiroft in the Halil basin: first preliminary report (2002-2008)", Iran 46: 69-103.

Nicholas, I.M. 1990. The Proto-Elamite Settlement at TUV, Malyan Excavation Report, W.M Sumner, Series editor, vol. 1, University Museum Monograph 69, University of Pennsylvania, Philadelphia.

Parzinger, H. 2011. "Sialk III pottery chronology", in A. Vatandoust, H. Parzinger and B. Helwing (eds.), Early Mining and Metallurgy on the Western Central Iranian Plateau, the First Five Years of Work, Archäologie in Iran und Turan, band 9, Verlag, Philipp von Zabern, Mayence: 128-95.

Petrie, C.A. 2013. "Ancient Iran and its neighbours: the state of play", in C. Petrie (ed.), Ancient Iran and Its neighbours: Local Developments and Long Range Interactions in the Fourth Millennium BC, British Institute of Persian Studies, Archaeological Monographs Series, Oxbow Books, Oxford: 1-24.

- in press. "Iran and Uruk Mesopotamia: chronologies and connections in the 4th millennium BC", in McMahon, A., Crawford, H. and Postgate, J.N. (eds), Preludes to Urbanism: Studies in the Late Chalcolithic of Mesopotamia in Honour of Joan Oates, McDonald Institute Monographs, Cambridge.

Petrie, C.A., Asgari Chaverdi, A. and Seyedin, M. 2009a. "Excavations at Tol-e Spid", in Potts, D.T., Roustaei K., Petrie, C.A. and Weeks, L.R. (eds.), The Mamasani Archaeological Project Stage One: A Report on the First Two Seasons of the ICAR - University of Sydney Joint Expedition to the Mamasani District, Fars Province, Iran, Archaeopress, BAR International Series 2044, Oxford: 89-134.

Petrie, C.A., Weeks, L.R., Potts, D.T. and Roustaei, K. 2009 b. "Perspectives on the cultural sequence of Mamasani", in Potts, D.T., Roustaei K., Petrie, C.A. and Weeks, L.R. (eds.), The Mamasani Archaeological Project Stage One: A Report on the First Two Seasons of the ICAR - University of Sydney Joint Expedition to the Mamasani District, Fars Province, Iran, Archaeopress, BAR International Series 2044, Oxford: 169-96.

Pollock, S. 2010. "Practices of daily life in fifth millennium B.C. Iran and Mesopotamia", in R.A. Carter and G. Philip (eds.), Beyond the Ubaid: Transformation and Integration in the Late Prehistoric Societies of the Middle East, Studies in ancient oriental civilization no. 63, The Oriental Institute of the University of Chicago, Chicago: 93-112.

Potts, D.T. 1977. "Tepe Yahya and the end of the 4th millennium on the Iranian Plateau", in J. Deshayes (ed.), Le plateau Iranien et l'Asie centrale des origines à la conquête islamique. Leurs relations à la lumière des documents archéologiques, Colloque no. 567 du C.N.R.S, Paris: 23-32.

- 1999. The Archaeology of Elam: Formation and Transformation of an Ancient Iranian State, Cambridge 
World Archaeology, Cambridge University Press, Cambridge.

- 2001. Excavations at Tepe Yahya, Iran 1967-1975, The Third Millennium, Peabody Museum of Archaeology and Ethnology, Harvard University, Cambridge, MA.

- 2009. "Bevel-rim bowls and bakeries: evidence and explanations from Iran and the Indo-Iranian borderlands", JCS 61: 1-23.

Potts, T.F. 1994. Mesopotamia and the East, an Archaeological and Historical Study of Foreign Relations ca. 3400-2000 $B C$, Oxford University Committee for Archaeology Monograph 37, Oxford.

Rothman, M.S. and Badler, V.R. 2011. "Contact and development in Godin period VI", in H. Gopnik and M.S. Rothman (eds.), On the High Road, the History of Godin Tepe, Iran, Bibliotheca Iranica: archaeology, art and architecture series 1, Mazda Publishers, Royal Ontario Museum, Costa Mesa: 67-137.

Schmidt, E.F., van Loon, M.N. and Curvers, H.H. 1989. The Holmes Expeditions to Luristan, Oriental Institute Publications, vol. 108, The Oriental Institute of the University of Chicago, Chicago.

Shahmirzadi, S.M. 2002. "A Short Outline on the Report of the 'Sialk Reconsideration Project' and The Ziggurat of Sialk", in S.M. Shahmirzadi (ed.), The Ziggurat of Sialk, Sialk Reconsideration Project, Report no. 1, Iranian Center for Archaeological Research, Tehran: 1-5.

Stève, M.-J. and Gasche, H. 1971. L'Acropole de Suse, Mémoires de la Délégation Archéologique en Iran 46, Geuthner, Paris.

- 1990. "Le tell de l'Apadana avant les Achéménides, contribution à la topographie de Suse", in F. Vallat (ed.), Contributions à l'histoire de l'Iran, Mélanges offerts à Jean Perrot, ERC, Paris: 15-60.

Sumner, W.M. 2003. Early urban life in the land of Anshan: Excavations at Tal-e Malyan in the highlands of Iran, Malyan Excavation Reports, William M. Sumner, Series editor, vol. III, University Museum Monograph 117, University of Pennsylvania, Philadelphia.

Vidale, M. 2011. “A Vessel for Building Another Vessel. A Technical Template of the Late 4th Millennium BCE in the CentralEastern of the Iranian Plateau?", Iranian Journal of Archaeological Studies 1/2: 9-16.

Vidale, M. and Desset, F. 2013. "Mahtoutabad (Konar Sandal south, Jiroft), preliminary evidence of occupation of a Halil Rud site in the early 4th millennium BCE", in C. Petrie (ed.), Ancient Iran and Its Neighbours: Local Developments and Long Range Interactions in the Fourth Millennium $B C$, British Institute of Persian Studies, Archaeological Monographs Series, Oxbow Books, Oxford: 233-51.

Voigt, M.M. and Dyson, Jr., R.H. 1992. "The Chronology of Iran, ca. 8000-2000 B.C.”, in R.W. Ehrich (ed.), Chronologies in Old World Archaeology, 3rd edition, 2 vols., The University of Chicago Press, Chicago/London: 122-78 (vol. 1) and 125-53 (vol. 2).

Weeks, L.R., Alizadeh, K., Niakan, L., Alamdari, K. (Trench A), Khosrowzadeh, A. and Zeidi, M. (Trench B). 2009. "Excavations at Tol-e Nurabad", in D.T. Potts, K. Roustaei, C.A. Petrie and L.R. Weeks (eds.), 2009. The Mamasani Archaeological Project Stage One: A Report on the First Two Seasons of the ICAR - University of Sydney Joint Expedition to the Mamasani District, Fars Province, Iran, Archaeopress, BAR International Series 2044, Oxford: 31-88.

Weiss, H. and Young, Jr., T.C. 1975. "The Merchants of Susa. Godin V and Plateau-Lowland Relations in the late Fourth Millennium B.C.", Iran 13: 1-17.

Whitcomb, D.S. 1971. The Proto-Elamite Period at Tal-i Ghazir, Iran, Athens, GA.

Wright, H. 1981. An Early Town on the Deh Luran Plain: Excavations at Tepe Farukhabad, Memoirs of the Museum of Anthropology no. 13, University of Michigan, Ann Arbor.

— 1997. “Tepe Farukhabad”, in E.M. Meyers (ed.), The Oxford Encyclopaedia of the Near East, vol. 5, Oxford University Press: 181-83.

- 2007. "Ancient agency: using models of intentionality to understand the dawn of despotism", in E.C. Stone (ed.), Settlement and Society, Essays Dedicated to Robert McCormick Adams, Cotsen Institute of Archaeology: Ideas, debates and perspectives vol. 3, Cotsen Institute of Archaeology, University of California, Los Angeles and the Oriental Institute of the University of Chicago: 173-84.

Wright, H.T. and Rupley, E.S.A. 2001. "Calibrated radiocarbon age determinations of Uruk-related assemblages", in M.S. Rothman (ed.), Uruk Mesopotamia and its Neighbors, Cross-Cultural Interactions in the Era of State Formation, School of American Research Press, Santa Fe: 85-122.

Wright, H., Miller, N. and Redding, R.W. 1980. "Time and process in an Uruk rural center", L'archéologie de l'Iraq: perspectives et limites de l'interprétation anthropologique des documents, Colloques internationaux du CNRS no. 580, Éditions du CNRS, Paris: 265-82.

Young, Jr., T.C. 1986. "Godin Tepe period VI/V and central western Iran at the end of the fourth millennium", in U. Finkbeiner and W.Röllig (eds.), Gamdat Nasr, Period or Regional Style?, Beihefte zum Tübinger Atlas des vorderen Orients, Ludwig Reichert Verlag, Wiesbaden: 212-28.

- 2004. "The Kangavar survey; periods VI to IV", in A. Sagona (ed.), A View from the Highlands, Archaeological Studies in Honour of Charles Burney, Ancient Near Eastern Studies, supplement 12, Peeters: 645-60.

Young, T.C. Jr. and Levine, L.D. 1986. "A summary of the ceramic assemblages of the central western Zagros from the middle Neolithic to the late third millennium B.C.", Préhistoire de la Mésopotamie, Éditions du CNRS, Paris: 15-53. 